\author{
UNIVERSIDADE DE SÃO PAULO \\ ESCOLA DE ENGENHARIA DE SÃO CARLOS \\ CENTRO DE RECURSOS HÍDRICOS E ECOLOGIA APLICADA \\ PÓS-GRADUAÇÃO EM CIÊNCIAS DA ENGENHARIA AMBIENTAL
}

RENATO BILLIA DE MIRANDA

\title{
A INFLUÊNCIA DO ASSOREAMENTO NA GERAÇÃO DE ENERGIA HIDRELÉTRICA: ESTUDO DE CASO NA USINA HIDRELÉTRICA DE TRÊS IRMÃOS - SP
}

São Carlos 
RENATO BILLIA DE MIRANDA

\section{A INFLUÊNCIA DO ASSOREAMENTO NA GERAÇÃO DE ENERGIA HIDRELÉTRICA: ESTUDO DE CASO NA USINA HIDRELÉTRICA DE TRÊS IRMÃOS - SP}

Dissertação apresentada à Escola de Engenharia de São Carlos, da Universidade de São Paulo, como parte dos requisitos para obtenção do título de mestre em Ciências da Engenharia Ambiental.

Orientador: Prof. Dr. Frederico Fábio Mauad

São Carlos

2011 
AUTORIZO A REPRODUÇÃO E DIVULGAÇÃO TOTAL OU PARCIAL DESTE TRABALHO, POR QUALQUER MEIO CONVENCIONAL OU ELETRÔNICO, PARA FINS DE ESTUDO E PESQUISA, DESDE QUE CITADA A FONTE.

Ficha catalográfica preparada pela Seção de Tratamento da Informação do Serviço de Biblioteca - EESC/USP

Miranda, Renato Billia de
A influência do assoreamento na geração de energia
hidrelétrica : estudo de caso na usina hidrelétrica de
Três Irmãos-SP. / Renato Billia de Miranda ; orientador
Frederico Fábio Mauad. -- São Carlos, 2011.
Dissertação (Mestrado-Programa de Pós-Graduação e Área
de Concentração em Ciências da Engenharia Ambiental) --
Escola de Engenharia de São Carlos da Universidade de São
Paulo, 2011.
1. Assoreamento. 2. Usina Três Irmãos. 3. AcquaNet. 4.
Setor hidroenergético - planejamento e gerenciamento. I.
Título.


Candidato(a): Engenheiro RENATO BILLIA DE MIRANDA.

Dissertação defendida e julgada em 23.02.2011 perante a Comissão Julgadora:

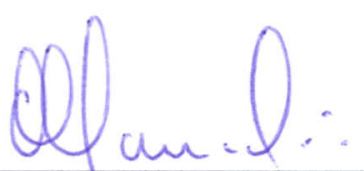

Prof. Dr. FREDERICO FABIO MAUAD - (Orientador)

(Escola de Engenharia de São Carlos/USP)

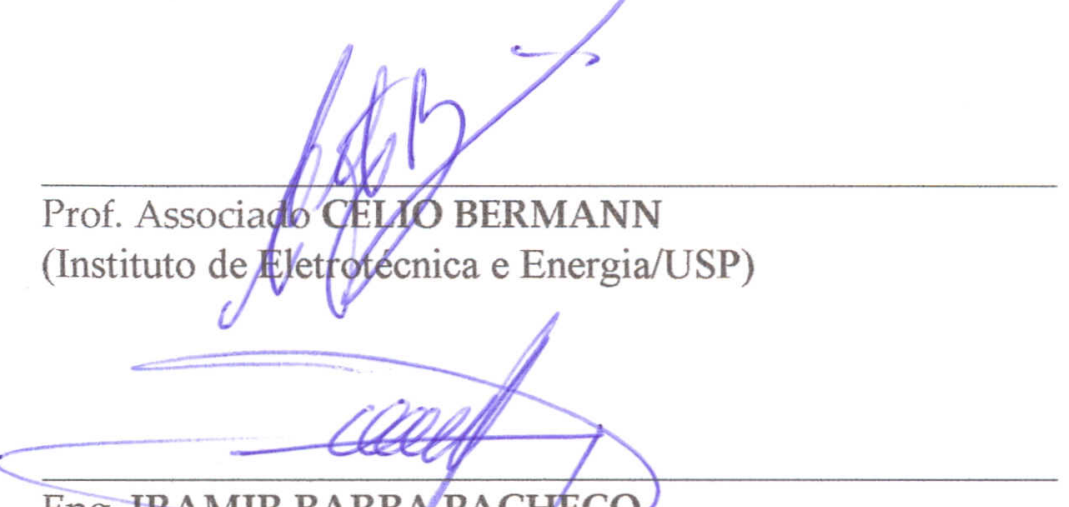

Eng. IRAMIR BARBA PACHECO

(Companhia Energétíca de São Paulo/CESP)
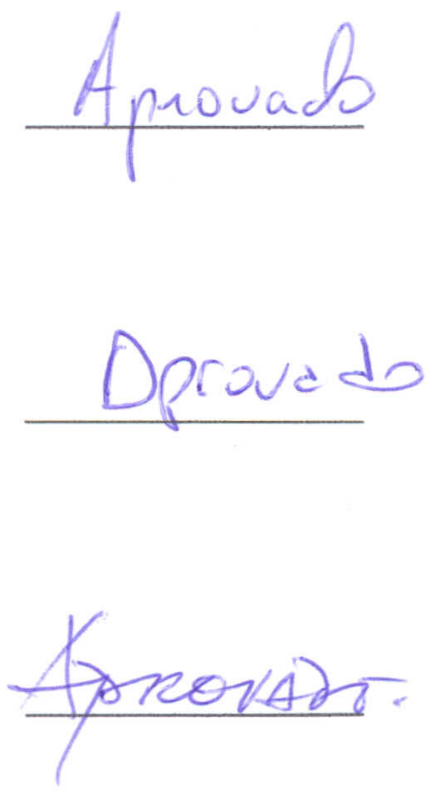

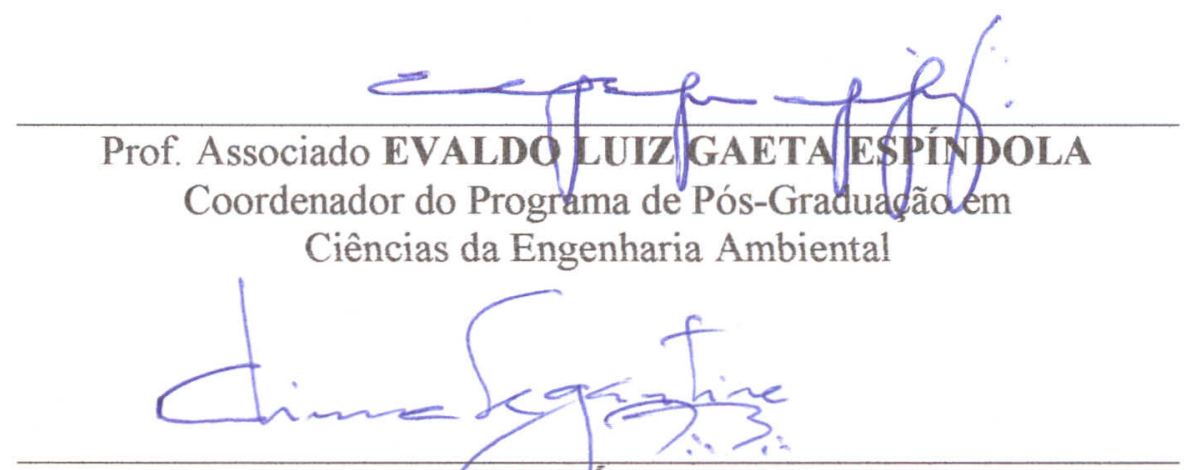

Prof. Associado PAULO CÉSAR LIMA SEGANTINE Presidente da Comissão da Pós-Graduação da EESC 
Dedico este trabalho às cinco pessoas mais importantes da minha vida: minha mãe Pilar, meu pai José, minha irmã Karina, meu irmão André e minha namorada Kátia. 


\section{AGRADECIMENTOS}

Agradeço:

Ao professor Dr. Frederico Fábio Mauad, pela orientação, amizade, conselhos e apoio para o desenvolvimento deste trabalho.

À CAPES, pela bolsa de estudo e pelo suporte financeiro para viabilização desta pesquisa, através do Projeto Pró-Engenharia Edital nº 029.

Ao Núcleo de Hidrometria do Centro de Recursos Hídricos e Ecologia Aplicada da Escola de Engenharia de São Carlos (USP), pelo suporte material, pessoal e técnico para desenvolvimento deste trabalho.

À CESP, pela disponibilização dos dados referentes à Usina de Três Irmãos. Especial agradecimento aos engenheiros Sérgio Zuculin, Antônio Ehrenberg, Alex Andrade, Sérgio Cerminaro e José Luppi.

Aos professores, Dr. Rubem La Laina Porto e Dra. Adelena Gonçalves Maia, pela ajuda e apoio no entendimento do software utilizado nesta pesquisa.

Ao professor Dr. Célio Bermann pela participação no exame de qualificação e defesa deste trabalho, pelas sugestões e considerações que foram muito importantes para este estudo.

Ao engenheiro Iramir Barba Pacheco pelas considerações e fundamental colaboração para elaboração final deste trabalho.

Aos professores, técnicos e funcionários do CRHEA, em especial, ao Cidão, Regina, Nelson, Zé Luiz, Jô, Michel e Rafael, por todo o apoio, ajuda e atenção. 
Aos amigos do Núcleo de Hidrometria: Márcia, Liliane, Miro, Ivo, Cesinha, Zé Berto, Artur, Gustavo, Marcus, Edwardo, André, Diego, Júlio, Taiana, Roberta e Juliana. Pela amizade, sugestões, trabalhos colaborativos e bate papos.

Aos amigos que fiz durante o curso de engenharia elétrica, em especial ao Douglas Rossi, André Cunha, Rafael Ueda e Eduardo Yudi.

Aos meus grandes amigos: Maurício Okado, Elaine Botter, Gustavo Pereira, Sérgio Costa, Anderson Costa, Jean Mazzoni, Allen Barros, Gyselle Uchoa, Lucas Melo, Elis Alves, pelas palavras de apoio, por entenderem minha distância e pelos inúmeros momentos de alegria.

À minha família de Valinhos que sempre entendeu minha ausência e me trata com muito carinho. José, Leide, Douglas, Karina e Deyvis, muito obrigado!

Aos meus queridos irmãos, Karina e André, pelo amor, carinho e amizade. Apesar de ser o irmão mais velho, muitas vezes me espelhei e aprendi com vocês.

À minha amada Kátia, pessoa especial que Deus colocou na minha vida e que me acompanha desde a graduação. Espero poder contar sempre com o seu apoio. Amo você!

Ao meu pai José, pelo exemplo de honestidade, esforço e perseverança. À minha mãe Pilar, meu exemplo de vida e meu eterno anjo da guarda, pelo amor e carinho. Só cheguei até aqui porque contei com o amor e apoio de vocês. Amo vocês.

À Deus acima de tudo, por me guiar e iluminar em mais uma etapa desta longa caminhada. 


\section{SUMÁRIO}

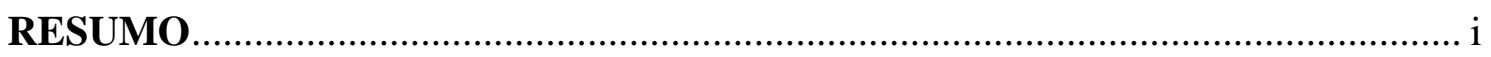

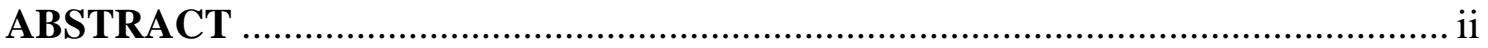

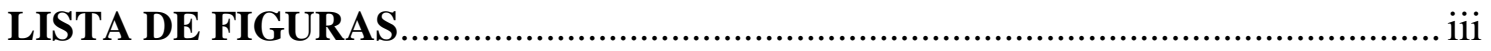

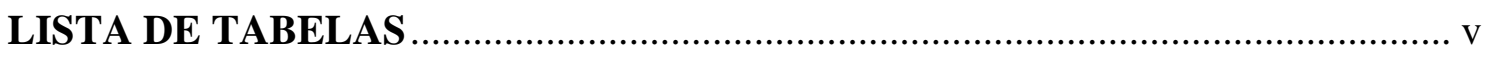

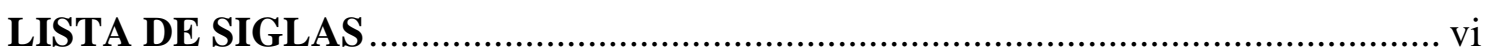

1. INTRODUÇÃ

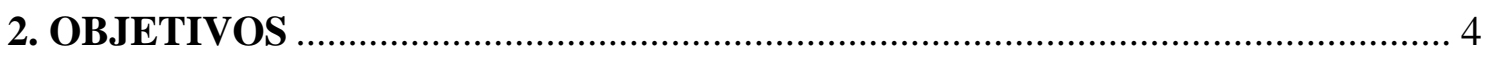

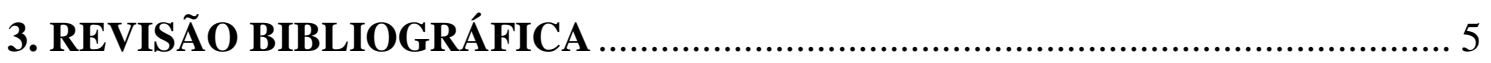

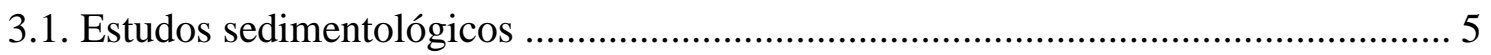

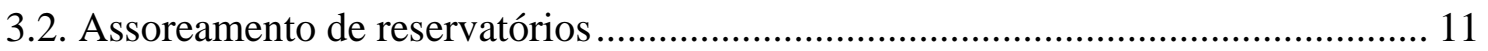

3.3. Medidas preventivas e corretivas para o controle do assoreamento de reservatórios

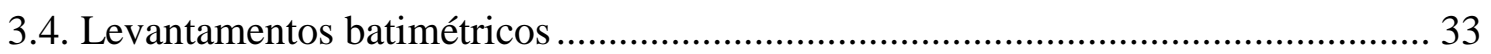

3.5. Modelos computacionais aplicados a análise de sistemas de recursos hídricos...... 39

3.5.1. Modelos de simulação em recursos hídricos ......................................................... 41

3.5.2. Modelos de otimização em recursos hídricos ....................................................... 42

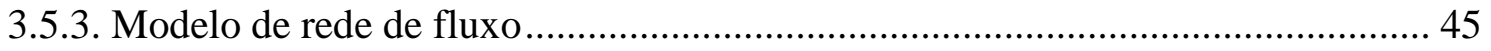

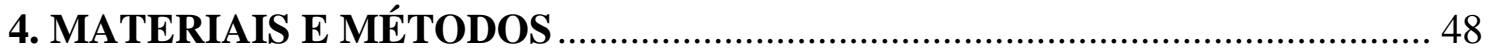

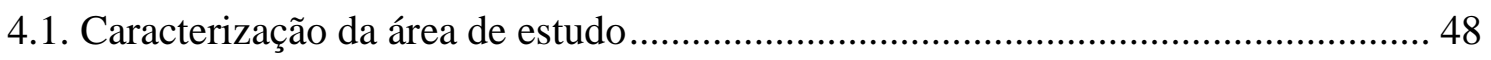

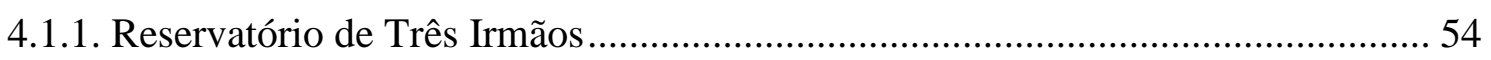

4.2. Dados de entrada do Reservatório de Três Irmãos ...................................................... 58

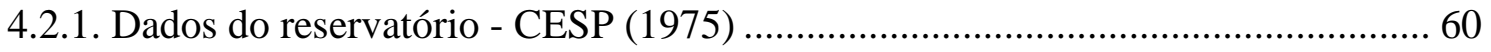

4.2.2. Dados do reservatório - Levantamentos batimétricos (2008)............................... 61

4.2.3. Extrapolação dos dados do reservatório para simulação da sua operação ........... 68

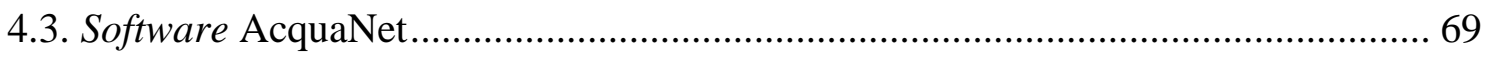

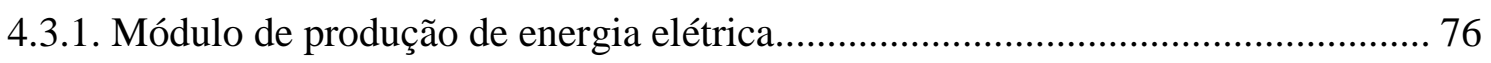

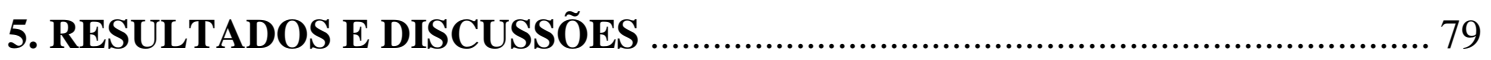

5.1. Simulação da operação do reservatório e da usina - AcquaNet .............................. 79

5.2. Influência do assoreamento na geração de energia elétrica.................................... 90

5.3. Medidas preventivas e corretivas para o controle do assoreamento no local de estudo 
6. CONCLUSÕES E RECOMENDAÇÕES

7. REFERÊNCIAS BIBLIOGRÁFICAS

107 


\section{RESUMO}

MIRANDA, R.B. A influência do assoreamento na geração de energia hidrelétrica: Estudo de caso na Usina Hidrelétrica de Três Irmãos - SP. 2011. 117 p. Dissertação (Mestrado) - Escola de Engenharia de São Carlos, Universidade de São Paulo, São Carlos, 2011.

Com a crescente demanda de energia elétrica há a necessidade da criação de novas fontes de energia e otimização das fontes já existentes. No caso de países que apresentam uma matriz energética predominantemente hidrelétrica como o Brasil, com grandes usinas e reservatórios, os estudos sedimentológicos e os levantamentos batimétricos se apresentam como importantes ferramentas para melhorar o planejamento e o gerenciamento dos recursos hídricos e energéticos. Atualmente, muitos reservatórios hidrelétricos operam com dados defasados devido, principalmente, ao contínuo processo de assoreamento dos reservatórios. Este fato faz com que as políticas de gestão e operação destes reservatórios sejam realizadas a partir de dados diferentes dos encontrados na realidade. Neste contexto, a dissertação apresenta um estudo de caso no Reservatório de Três Irmãos (SP), onde foi realizado um levantamento batimétrico em 2008, e a partir da comparação dos dados obtidos neste levantamento com os dados fornecidos pela concessionária de energia, de 1975, foi possível estimar as perdas de volume total, útil e morto do reservatório que correspondem a 14,3\%, 14,5\% e 14,2\%, respectivamente. A partir da observação destas modificações nos dados operacionais do reservatório em estudo, foi realizada a simulação da operação do reservatório e da usina hidrelétrica por meio do software AcquaNet, com a intenção de analisar qual a interferência do assoreamento do reservatório na geração de energia elétrica, durante o período de 1993 a 2008. Com os resultados foi constatado que a diminuição do volume útil do reservatório (devido ao assoreamento) acarretou na redução da energia gerada pela usina durante o período analisado. Também foi possível estimar as perdas financeiras da concessionária de energia com a redução da produção energética. Foram sugeridas, ainda, algumas medidas preventivas e corretivas para a redução do processo de assoreamento do reservatório em estudo.

Palavras-chave: Assoreamento, Usina de Três Irmãos, AcquaNet, Setor hidroenergético planejamento e gerenciamento. 


\begin{abstract}
MIRANDA, R.B. The influence of silting in the generation of hydroelectric energy: Case study at Três Irmãos power plant - SP. 2011. 117 p. Dissertation (Master) - Escola de Engenharia de São Carlos, Universidade de São Paulo, São Carlos, 2011.
\end{abstract}

With the increasing demand of energy, it is necessary to create new sources and optimize the ones that already exist. In the case of countries that present an energy matrix predominantly hydroelectric such as Brazil, where there are huge power plants and reservoirs, the studies on sedimentation and beating surveys are presented as important tools to sharpen the planning and the management of water and energy resources. Currently, most of the hydroelectric reservoirs operate in gapped data, due to, mainly, the continuing process of reservoirs silting. This makes management policies and operation of these reservoirs be performed from data that differ from the ones found in reality. In this context, this dissertation presents a case study at the Três Irmãos Reservoir (SP), where a beating survey was carried out in 2008, and, from the comparison of the data revealed in that survey with the data provided by the power utility in 1975, it was possible to estimate the losses of total capacity, live storage and void volume of the reservoir, which correspond to $14,3 \%, 14,5 \%$ e $14,2 \%$, respectively. From the observation of these operational data modification of the reservoir under study was performed the simulate of the operation of the reservoir and hydroelectric plant with the employing of the AcquaNet software with the intention to look into the interference of silting of the reservoir in generate electricity during the period 1993 to 2008. With the results was found that the decrease in the capacity of the reservoir (due to siltation) resulted in the reduction of energy generated by the plant during the period analyzed. With this verification, it was also possible to estimate the financial losses of the power utility with the reduction of energy production. Was suggested also, some preventive and corrective measures to reduce siltation process in the reservoir under study.

Key-words: Silting, Três Irmãos power plant, AcquaNet, hydropower sector - planning and management. 


\section{LISTA DE FIGURAS}

Figura 1. Formação de depósitos de sedimentos nos reservatórios e seus principais problemas.

Figura 2. Representação de um sistema através de uma rede de fluxo.

Figura 3. Unidades de Gerenciamento de Recursos Hídricos do Estado de São Paulo, com destaque para a UGRHI n ${ }^{\circ} 19$ - Baixo Tietê.

Figura 4. Área e população da Bacia do Baixo Tietê comparada ao Estado de São Paulo.....49

Figura 5. Classificação das UGRHIs segundo a Secretaria do Meio Ambiente, com destaque a UGRHI-19. 50

Figura 6. Distribuição dos diferentes usos do solo na UGRHI-19......................................52

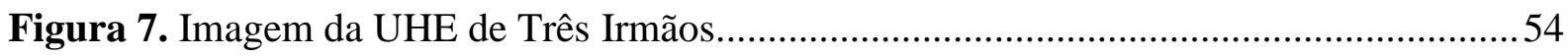

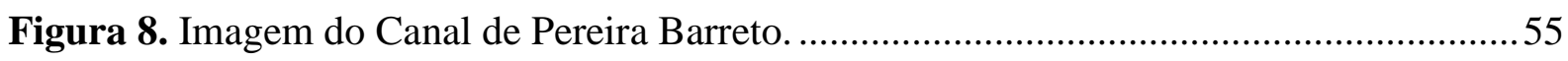

Figura 9. Esquema unifilar dos aproveitamentos hidrelétricos do Baixo Tietê/Paraná. .........56

Figura 10. Seções batimétricas no Reservatório de Três Irmãos............................................... 62

Figura 11. Equipamentos utilizados na batimetria do Reservatório de Três Irmãos.

Figura 12. Ilustração de um barco utilizando o ecobatímetro para medição da área submersa.

Figura 13. Curva e polinômio cota $v s$. área do reservatório obtidos a partir da batimetria.....65

Figura 14. Ilustração do método empregado para o cálculo do volume do reservatório particionamento pelas curvas de nível.

Figura 15. Curva e polinômio cota vs. volume do reservatório obtido a partir da batimetria. 67

Figura 16. Estrutura do AcquaNet com destaque ao módulo de energia. .74

Figura 17. Ilustração simplificada de uma usina hidrelétrica. .76

Figura 18. Representação no AcquaNet do Reservatório de Três Irmãos e das suas principais demandas.

Figura 19. Janela de configuração do AcquaNet - Características físicas do reservatório para o cenário de 1993.

Figura 20. Janela de configuração do AcquaNet - Características físicas do reservatório para o cenário de 2008 . 83

Figura 21. Janela de configuração do AcquaNet - Prioridade/Volume meta. .84 
Figura 22. Vazão anual afluente ao Reservatório de Três Irmãos no período de 1975 a 2008.

Figura 23. Janela de configuração do AcquaNet - Vazões naturais e taxas de evaporação... 85

Figura 24. Janela de configuração do AcquaNet - Energia: prioridade da geração e potência

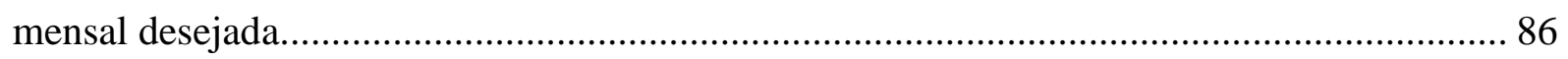

Figura 25. Janela de configuração do AcquaNet - Dados de geração energia........................ 87

Figura 26. Janela de configuração do AcquaNet - Dados da demanda jusante. ..................... 88

Figura 27. Janela de configuração do AcquaNet - Dados da demanda eclusa....................... 88

Figura 28. Janela de configuração do AcquaNet - Dados da demanda fictícia de dreno....... 89

Figura 29. Cultivo de cana-de-açúcar próximo às margens do Reservatório de Três Irmãos. 97

Figura 30. Presença de pastagem e gado nas margens do Reservatório de Três Irmãos. ....... 97

Figura 31. Área com solo exposto próxima à margem do reservatório na época do plantio da

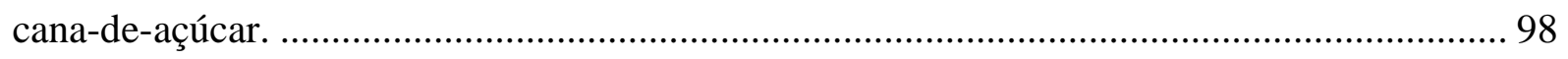

Figura 32. Localização dos depósitos de sedimentos e escavações no Reservatório de Três Irmãos. 101 


\section{LISTA DE TABELAS}

Tabela 1. Principais métodos utilizados em levantamentos topobatimétricos de rios e reservatórios.

Tabela 2. Frequência aconselhada para levantamentos topobatimétricos em reservatórios....36

Tabela 3. Resumo das demandas consuntivas da UGHRI Baixo Tietê..................................51

Tabela 4. Distribuição (hectare e percentual) dos diferentes usos do solo na UGRHI-19......52

Tabela 5. Principais características do Reservatório e da UHE de Três Irmãos.......................56

Tabela 6. Vazão afluente ao Reservatório de Três Irmãos.....................................................58

Tabela 7. Taxas de evaporação líquida do Reservatório de Três Irmãos (mm). .....................60

Tabela 8. Parte dos dados de cota $v s$. área $v s$. volume do reservatório fornecidos pela CESP.

Tabela 9. Parte dos dados de cota vs. área do reservatório obtidos a partir dos levantamentos batimétricos.

Tabela 10. Parte dos dados de cota $v s$. volume do reservatório obtidos a partir dos levantamentos batimétricos. .66

Tabela 11. Principais demandas do reservatório e suas prioridades de atendimento. 81

Tabela 12. Comparação entre os valores de volumes do reservatório.

Tabela 13. Comparação entre os principais resultados obtidos nas simulações do reservatório para o período de 1993 a 2008

Tabela 14. Estimativa das perdas médias mensais energética e financeira entre os dois cenários propostos. 


\section{LISTA DE SIGLAS}

ANA - Agência Nacional de Águas

ANEEL - Agência Nacional de Energia Elétrica

CATI - Coordenadoria de Assistência Técnica Integral

CRHEA - Centro de Recursos Hídricos e Ecologia Aplicada

CESP - Companhia Energética de São Paulo

CBH-BT - Comitê da Bacia Hidrográfica do Baixo Tietê

CETESB - Companhia Ambiental do Estado de São Paulo

CHESF - Companhia Hidro Elétrica do São Francisco

CETEC - Centro Tecnológico da Fundação Paulista de Tecnologia e Educação

DAEE - Departamento de Águas e Energia Elétrica

CONAMA - Conselho Nacional do Meio Ambiente

DGPS - Differencial Global Positioning System

FIPAI - Fundação para o Incremento da Pesquisa e do Aperfeiçoamento Industrial

IEA - Instituto de Economia Agrícola

IPH - Instituto de Pesquisas Hidráulicas

IPT - Instituto de Pesquisas Tecnológicas do Estado de São Paulo

ICOLD - International Commission on Large Dams

LabSid - Laboratório de Sistemas de Suporte a Decisão

LUPA - Levantamento Censitário das Unidades de Produção Agropecuária

MDL - Mecanismo de Desenvolvimento Limpo

MDT - Modelo Digital do Terreno

MRF - Modelo de Rede de Fluxo

N.A. - Nível d'água

ONS - Operador Nacional do Sistema Elétrico

Proálcool - Programa Nacional do Álcool

SEADE - Fundação Sistema Estadual de Análise de Dados

SSD - Sistemas de Suporte à Decisão

UGRHI - Unidade de Gerenciamento de Recursos Hídricos

UHEs - Usinas Hidrelétricas

USCOLD - United States Committee on Large Dams

SABESP - Companhia de Saneamento Básico do Estado de São Paulo 


\section{INTRODUÇÃO}

Os reservatórios são utilizados pelo homem há milhares de anos e, com o passar do tempo, suas funções e usos sofreram significativas alterações. $\mathrm{Na}$ sua origem serviam, geralmente, para o atendimento local das necessidades urbanas, rurais e agrícolas. No entanto, atualmente, os reservatórios são projetados e construídos para diversas finalidades (usos múltiplos), tais como: abastecimento, irrigação, navegação, geração de energia, entre outros.

Apesar dos inúmeros benefícios que os reservatórios propiciam, as construções das suas barragens acarretam uma série de modificações no regime de vazão do rio, que alteram significativamente o transporte de sedimentos pelos cursos d'água.

Segundo Coiado (2001), todo reservatório, independente da sua finalidade e característica de operação, está fadado ao processo de assoreamento. Os sedimentos carreados pelo curso d'água podem se acumular no compartimento do volume útil do reservatório ou em cotas inferiores, reduzindo seu volume morto e sua vida útil. Estes sedimentos, quando depositados no volume útil, alteram a vazão regularizada, a capacidade de geração de energia elétrica e o atendimento de outros usos consuntivos e não consuntivos da água.

Os efeitos dos sedimentos nos reservatórios são diversos, dentre os quais cabe destacar: a redução da capacidade de armazenamento; abrasão dos canais de fuga e das pás das turbinas; formação de bancos de areia com interferência na navegação; e, em alguns casos, obstrução da tomada de água.

$\mathrm{Na}$ análise do assoreamento em reservatórios pela ótica da geração de energia é possível verificar que, além da redução do faturamento da concessionária de energia devido à perda de volume útil do reservatório (e consequente redução na produção energética), os sedimentos também podem acarretar em custos adicionais por conta de desgastes dos 
equipamentos eletromecânicos, além de investimentos em procedimentos para minimizar os problemas ocasionados pelo acúmulo de sedimentos.

Apesar do conhecimento desses problemas, nota-se que os estudos sedimentológicos (na maioria dos projetos e estudos realizados em reservatórios) não recebem a devida atenção e, quando realizados, muitas vezes ocorrem de forma incompleta. Desta mesma forma, podese verificar na literatura técnica e acadêmica que não há muitos estudos que avaliam as perdas energéticas por problemas ambientais (como o assoreamento), embora esta seja uma questão cada vez mais evidente.

Outro fato que merece ser destacado é que, atualmente, muitos reservatórios são operados a partir de dados desatualizados devido, principalmente, ao contínuo processo de assoreamento que eles sofrem. Este fato faz com que as políticas de gestão e operação destes reservatórios sejam realizadas a partir de dados diferentes dos encontrados na realidade.

Uma das alternativas apresentadas nesta pesquisa para este problema são os levantamentos batimétricos que podem ser utilizados na determinação ou atualização dos dados operacionais dos reservatórios e na avaliação das suas reais condições e características.

Em virtude dos fatos apresentados e de outros que serão abordados no decorrer desta dissertação, os estudos sedimentológicos em reservatórios hidrelétricos e os levantamentos batimétricos se apresentam como importantes ferramentas para, entre outros fatores, melhorar a geração de energia, principalmente pela forte relação existente entre os recursos hídricos e a geração hidrelétrica no país.

Além destes estudos possibilitarem um melhor planejamento hídrico e energético, eles também auxiliam no acompanhamento do processo de assoreamento e em medidas preventivas e corretivas para redução do assoreamento em reservatórios hidrelétricos e consequente melhora na produção energética, principalmente das pequenas e médias centrais hidrelétricas, nas quais este problema tende a ser maior. Assim, esta possível melhora 
energética pode ser utilizada como complemento à construção de novas usinas, tendo em vista as questões sociais, financeiras e ambientais que envolvem a construção de novos empreendimentos energéticos.

Com este enfoque, o presente trabalho tem como objetivo analisar a influência do assoreamento na geração de energia elétrica, tomando como estudo de caso, a Usina Hidrelétrica e o Reservatório de Três Irmãos, localizados a noroeste do Estado de São Paulo. 


\section{OBJETIVOS}

O objetivo deste estudo é analisar os problemas e as perdas energéticas ocasionadas pelo assoreamento de reservatórios hidrelétricos e ressaltar a importância dos estudos sedimentológicos e dos levantamentos batimétricos em projetos destinados à geração de energia. Para tanto, foi realizado um estudo de caso na Usina Hidrelétrica de Três Irmãos $(\mathrm{SP})$.

Os objetivos específicos do estudo foram:

- Simular a operação do Reservatório de Três Irmãos no período de 1993 a 2008, por meio do software AcquaNet, utilizando os dados do reservatório de 1975 (CESP) e 2008 (levantamentos batimétricos - Núcleo de Hidrometria);

- Analisar o atendimento da demanda de água para a geração de energia elétrica da Usina Hidrelétrica de Três Irmãos frente às simulações realizadas;

- Verificar se houve redução energética entre o período analisado nas simulações (1993 a 2008) e, caso tenha ocorrido, estimar as prováveis perdas financeiras decorrentes desta redução;

- Propor possíveis medidas preventivas e corretivas para a redução do processo de assoreamento no reservatório em estudo. 


\section{REVISÃO BIBLIOGRÁFICA}

\subsection{Estudos sedimentológicos}

Segundo Carvalho (2008), sedimento pode ser descrito como a partícula derivada de rochas ou de materiais biológicos que pode ser transportado por fluido (como a água e o vento) do seu ambiente de origem para os locais de deposição.

De acordo com o mesmo autor, a disciplina que estuda os sedimentos é a sedimentologia que tem como base os processos hidroclimatológicos e quando restrita aos cursos d'águas e lagos recebe o nome de hidrossedimentologia. Entre as diversas aplicações da sedimentologia, uma das mais difundidas é a avaliação do assoreamento e da vida útil de reservatórios.

Os processos e estudos sedimentológicos são complexos e dependem de diversos fatores. Eles são de grande importância, principalmente no caso de países com grande quantidade de recursos hídricos e com matriz energética predominantemente hidráulica, como é o caso do Brasil.

O termo sedimentação se refere aos processos de erosão, transporte de sedimentos e sua respectiva deposição (assoreamento). A erosão, que corresponde à separação e remoção das partículas das rochas e dos solos devido à ação das águas, dos ventos, entre outros, é o processo inicial da sedimentação e representa a origem dos problemas derivados do sedimento no meio ambiente (CARVALHO, 2008).

Desse modo, os primeiros aspectos que devem ser analisados na questão dos estudos sedimentológicos são quanto à produção de sedimento e suas áreas fontes. Neste contexto, é essencial o conhecimento das relações entre o uso do solo e a erosão, pois os sedimentos presentes no curso d'água são originados, em grande parte, da erosão da bacia hidrográfica, das margens e dos próprios leitos dos rios. 
Segundo Salomão (1991), os processos erosivos podem ser classificados em: erosão natural e antrópica. O primeiro grupo é o resultado das influências dos agentes naturais que atuam na degradação dos solos e o segundo grupo é a consequência das intervenções humanas sobre o meio físico (desmatamento, agricultura, atividades mineradoras e expansão urbana desordenada, entre outros).

Os processos erosivos são fenômenos naturais do ciclo hidrogeológico terrestre, no entanto, eles têm sido intensificados pelo homem. Diversos estudos e autores (MORGAN, 1986 ${ }^{1}$; STOCKING, 1987² LAL, 1990³ , entre outros) apresentam que a interferência do homem sobre o solo provoca o desenvolvimento e a intensificação dos processos erosivos. Por sua vez, estas intervenções nas bacias hidrográficas têm ocasionado uma produção cada vez maior de sedimentos que são transportadas para os rios.

Rocha (1997) enfatiza que a destruição do meio ambiente deve-se, principalmente, ao mau uso da agricultura e pecuária, fato este que acarreta na deterioração física, social, econômica e ambiental das bacias hidrográficas do Brasil.

Wilkinson (2005) também cita as atividades exercidas pelo homem como as principais causadoras de denudação da superfície terrestre, superando a soma de todos os processos naturais que agem na terra.

Da mesma forma, Carvalho et al. (2000a, p. 6-7) afirmam que:

\footnotetext{
“Atividades humanas introduzem uma profunda influência na erosão. Sob determinadas circunstâncias, as taxas de erosão são 100 vezes maiores, com a interferência humana, do que seriam apenas considerando-se em termos geológicos." (CARVALHO et al., 2000a, p. 6-7).
}

\footnotetext{
${ }^{1}$ MORGAN, R.P.C. (1986). Soil erosion and Conservation. Longman Group, England. 298 p.

${ }^{2}$ STOCKING, M. (1987). Measuring Land Degradation. In: BLAIKIE, P. \& BROOKFIELD, H. (eds.). Land Degradation and Society. England. p. 177-194.

${ }^{3}$ LAL, R. (1990). Soil Erosion in the Tropics - Principles and Management. McGraw-Hill, Inc. New York. $580 \mathrm{p}$.
} 
Muller (1995) ressalta que a erosão é um problema de duas faces: a primeira deve-se ao fato da mesma dilapidar camadas férteis de solos, prejudicando terrenos utilizados para agricultura; e a segunda quanto à deposição dos materiais erodidos em leitos de rios e reservatórios interferindo nas funções e utilizações dos mesmos.

Do mesmo modo, Branco et al. (1998) citam que os processos erosivos removem as camadas superficiais dos solos reduzindo a produtividade dos mesmos e que os sedimentos originados através destes processos, além de prejudicar a qualidade das águas, servem como veículo a outros poluentes (como fertilizantes ou produtos químicos) que são absorvidos a estes materiais.

Os processos erosivos também provocam outros problemas em cursos d'águas e reservatórios, como: aumento dos custos de tratamento de água, desequilíbrio do balanço de oxigênio dissolvido na água, danos no crescimento e desenvolvimento de espécies aquáticas (devido à turbidez da água e redução da capacidade de propagação da luz, entre outros), diminuição da capacidade de armazenamento dos reservatórios e consequente redução do potencial de geração energia elétrica (BARROSO e SILVA, 1992).

A segunda etapa do processo de sedimentação é o transporte dos sedimentos. Assim como a questão da erosão, o estudo do transporte dos sedimentos também é muito importante para a caracterização da bacia hidrográfica, quantificação dos impactos causados pelas ações antrópicas na região e para a estimativa da sedimentação em corpos hídricos.

Como ressaltado em diversos estudos, entre eles Carvalho (2008), o transporte de sedimentos depende de diversos fatores como: a forma, o tamanho e o peso do sedimento e as forças exercidas pela ação de escoamento. Além destes fatores, o tipo, a cobertura e o uso do solo; a topografia e a formação geológica do terreno, e a quantidade e intensidade das chuvas são outros fatores que influenciam no transporte dos sedimentos. 
Todos os cursos d'água apresentam a propriedade inerente de transportar sedimentos (partículas de rochas, solos e de matéria orgânica), seja em suspensão, arraste, saltação, rolamento/escorregamento ou por combinação destas maneiras (BRANCO e ROCHA, 1977; MULLER, 1995; SUGUIO e BIGARELLA, 1979).

Esses diversos meios de transportes devem-se ao fato de que os sedimentos que chegam até os cursos d'água são de diferentes tipos e características. Geralmente, os sedimentos com maior granulometria movimentam-se como carga de fundo em corpos hídricos, enquanto as partículas mais finas são transportadas em suspensão na coluna d'água (NAGLE et al., 1999).

A quantidade de sedimentos transportada varia a cada curso d'água. Carvalho (2008) e Muller (1995) citam que os corpos hídricos têm a capacidade de transportar uma determinada quantidade máxima de sedimentos, que é conhecido como valor de saturação, e que depende de diversos fatores como: a vazão e a declividade do curso d'água; e o tipo, a granulometria e o peso específico do sedimento.

Ainda segundo estes autores, quando o valor de saturação é maior que a quantidade de sedimento transportado (saturação), há formação de depósito nos corpos hídricos - canais, lagos, rios e reservatórios - e quando este valor é menor (insaturação), há uma tendência a processos erosivos nas margens e leitos dos corpos hídricos.

Conforme afirma Glymph (1973), todo corpo hídrico, normalmente, tende a apresentar um equilíbrio em relação ao transporte de sedimento.

McCully (2001) cita que, apesar do desenvolvimento científico, ainda é difícil estimar com precisão a quantidade de sedimento que é transportada pelos rios. Ainda segundo o autor, a medição do material sólido que é carreada por um curso d'água é geralmente mais custosa e complexa do que a medida do volume líquido (vazão). 
Conforme Carvalho (2008) apresenta, os principais problemas ocasionados pelo transporte de sedimento são:

- Sedimentos em suspensão prejudicam o uso da água para diversos fins (consumo, abastecimento, recreação, entre outros) além de interferir e/ou impedir a penetração da luz e calor nos corpos hídricos, necessária para fotossíntese e salubridade dos corpos hídricos;

- Os sedimentos atuam como portadores de outros poluentes (nutrientes químicos, inseticidas e metais pesados) e de bactérias e vírus;

- Os sedimentos em suspensão podem causar abrasão em equipamentos eletromecânicos (como as turbinas) e estruturas hidráulicas (comportas e eclusas) produzindo redução da eficiência ou danos aos mesmos.

Bhuyan et al. (2002) também ressaltam os problemas causados pelo transporte de sedimento, principalmente pelo fato da grande utilização, atualmente, de pesticidas e fertilizantes que podem ser absorvidos pelos solos e sedimentos e, através do seu transporte, causar poluição dos cursos d'água e aumento nos problemas de saúde humana e dos ecossistemas.

Do mesmo modo, Paiva et al. (1998) citam que o transporte de sedimentos, além de favorecer a poluição química e física, também causa aumento nos custos de tratamento de água para diversos usos e provoca danos para a vida aquática.

No entanto, mesmo com todos os problemas apresentados anteriormente que envolvem questões econômicas, sociais e ambientais, poucas ações têm sido tomadas, por agentes públicos e privados, para evitar ou minimizar estes problemas, tanto sobre os aspectos 
da erosão quanto do transporte de sedimentos que, além dos fatos mencionados, resultam em um problema ainda mais complexo que é o assoreamento dos corpos hídricos. 


\subsection{Assoreamento de reservatórios}

A construção de um reservatório gera uma série de modificações físicas, ambientais e sociais nos locais em que são instalados.

Conforme Bermann (2007) apresenta, um dos principais impactos sociais desencadeados pela instalação das usinas hidrelétricas e seus respectivos reservatórios é o deslocamento compulsório da população que reside nas regiões onde serão construídos estes reservatórios.

Segundo o autor, estima-se que a construção das usinas hidrelétricas até hoje no Brasil:

“[...] resultaram em mais de $34.000 \mathrm{~km}^{2}$ de terras inundadas para a formação dos reservatórios, e na expulsão - ou "deslocamento compulsório" - de cerca de 200 mil famílias, todas elas populações ribeirinhas diretamente atingidas" (BERMANN, 2007, p. 142).

McCully (2001) também ressalta os problemas sociais e ambientais causados pela instalação dos reservatórios como grandes áreas inundadas e o deslocamento populacional. De acordo com o autor, pelo menos $400.000 \mathrm{~km}^{2}$ foram inundados no mundo devido à construção de reservatórios.

Quanto ao deslocamento populacional, o mesmo autor cita que é difícil quantificar corretamente o número de pessoas que foram deslocadas pela instalação dos reservatórios, pois raramente são coletados e produzidos dados confiáveis a respeito deste assunto. Para exemplificar a magnitude dos deslocamentos populacionais, McCully (2001) cita o caso da barragem de Três Gargantas, no Rio Yangtzé (China), que deve deslocar, até o final do projeto, cerca de 1.300 .000 pessoas.

Além dos problemas citados anteriormente, a instalação dos reservatórios também provoca modificações no equilíbrio sedimentológico dos cursos d'água, pois propiciam uma 
significativa redução da velocidade do fluxo d'água que, por sua vez, ocasiona a deposição dos sedimentos transportados (GLYMPH, 1973; CARVALHO et al., 2000b).

Desta forma, os reservatórios funcionam como grandes bacias de retenção de sedimentos, uma vez que proporcionam condições favoráveis para a deposição dos materiais transportados pelo curso d'água.

Como visto anteriormente, o assoreamento dos corpos hídricos e reservatórios é a última etapa do processo de sedimentação, que tem início com a produção dos sedimentos e seu consequente transporte, e é apontado por muitos autores, como um dos principais problemas originados pelos processos erosivos em uma bacia hidrográfica.

O processo de deposição de sedimentos geralmente acontece em depressões naturais de terreno e ocorre quando a quantidade de sedimentos excede a capacidade de transporte. Infanti e Fornasari (1998) descrevem que o processo de assoreamento ocorre quando a força do agente transportador é superada pela força da gravidade do material transportado ou nos casos em que ocorre super-saturação no transporte dos sedimentos.

A deposição de sedimentos em reservatório é um processo complexo que apresenta inúmeros fatores de influência, conforme apresentado por Dendy ${ }^{4}$ (1968 apud MAIA, 2006, p. 5-6):

\footnotetext{
"Muitos parâmetros da bacia hidrográfica e do reservatório influenciam a taxa de sedimentação do reservatório. Alguns dos mais importantes são: o tamanho e a forma do reservatório; a razão entre a capacidade do reservatório e tamanho da bacia; razão entre a capacidade do reservatório e o deflúvio afluente; topografia da bacia, uso da terra e cobertura vegetal; declividade e densidade da rede de canais; e características físicas e químicas do sedimento afluente." (DENDY, 1968, p. 137, apud MAIA, 2006, p. 5-6).
}

\footnotetext{
${ }^{4}$ DENDY, F.E. (1968). Sedimentation in the Nation's Reservoirs. Journal of Soil and Water Conservation, v. 23, jul/aug, p. 135-137.
} 
Outro fator importante que influencia na taxa de sedimentação é a região onde está localizado o reservatório. Segundo Goldsmith e Hildyard (1984), estas taxas são pequenas em reservatórios localizados em zonas temperadas e muito elevadas em regiões de zonas tropicais. Segundo os autores, este fato deve-se, principalmente, às consequências do desmatamento e da quantidade de sedimentos produzidos e transportados nos solos tropicais.

Um dos principais problemas causados pela deposição de sedimentos em reservatório é a redução do seu volume útil, fato este que prejudica o atendimento da demanda hídrica dos seus múltiplos usuários, como o abastecimento público e industrial, a irrigação, a geração de energia, entre outros.

Diversos estudos, nacionais e internacionais, apresentam os problemas decorrentes do assoreamento. Dentre estes estudos, cabe destacar Carvalho (2008; 2000), Muller (1995) e Environmental Protection Agency (1976) os quais citam que o assoreamento tem como principais consequências:

- Redução do volume de água armazenado no reservatório;

- Obstrução de canais de irrigação, navegação e trechos de cursos d'água;

- Afogamento de locais de desovas, alimentação e abrigo de peixes;

- Formação de bancos de areia dificultando e alterando rotas de navegação;

- Dificuldade ou impedimento da entrada de água em estruturas hidráulicas de sistemas de captação;

- Degradação da qualidade da água para consumo e consequente aumento dos custos de tratamento;

- Aumento da turbidez da água, que prejudica os aproveitamentos hídricos e reduz as atividades de fotossíntese;

- Alteração, destruição e degradação de ecossistemas aquáticos; 
$\mathrm{O}$ assoreamento não apresenta problemas somente a montante da barragem, mas também a jusante, pois a água escoada tende a erodir as margens e os leitos do canal de escoamento, devido ao fato de possuir uma carga sólida geralmente menor do que o valor de saturação (CARVALHO, 2008). Este fato também é destacado por Coiado (2001) que cita:

\footnotetext{
“[...] A jusante da barragem, tem-se como consequência principal, o aumento da erosão devido ao desequilíbrio provocado pela retirada da carga natural de sedimentos do escoamento" (COIADO, 2001, p. 395).
}

Paiva et al. (1998) ressaltam que além dos problemas citados anteriormente, o assoreamento também provoca aumento na frequência e intensidade das inundações nas áreas circunvizinhas aos reservatórios.

A redução gradual na produção de energia é outro grave problema ocasionado pela deposição de sedimentos em reservatórios. Maia e Villela (2009) ressaltam que além da redução de receita com a produção energética, o assoreamento também pode ocasionar problemas de manobras de operação nas estruturas hidráulicas da usina e gastos em investimentos para dragagem de sedimentos nas proximidades da tomada d'água.

A Agência Nacional de Águas - ANA (2009) também cita as influências do assoreamento sobre a questão energética destacando a redução gradual de geração de energia e as dificuldades de operação da tomada d'água, das válvulas de descarga e das comportas, entre outros.

Segundo Almeida e Carvalho (1993), o Brasil apresenta diversos aproveitamentos hidrelétricos que tiveram sua capacidade de geração reduzida ou até mesmo a operação interrompida devido a problemas de assoreamento dos seus reservatórios. Quando os sedimentos atingem a altura da tomada d'água da usina, eles passam a escoar junto com a 
água em grande quantidade, fato este que pode impedir completamente a operação da usina (CARVALHO e CATHARINO, 1993).

Pode-se verificar pela literatura que são vários os fatores locais que influenciam no processo de sedimentação, principalmente quanto à deposição e distribuição dos sedimentos nos reservatórios, como: clima, pluviometria, hidrologia, formação geológica, topografia, cobertura vegetal, tipo e uso do solo, composição química das águas e dos sedimentos, entre outros.

Segundo Brune e Allen (1941) e Glymph (1973 apud COELHO, 1993), os principais fatores que influenciam na quantidade de sedimento que será depositado no reservatório são a quantidade de material em suspensão enviado para o reservatório aliada a capacidade de retenção do reservatório e o seu modo de operação.

Carvalho (2000) cita que os principais fatores que influenciam na formação dos depósitos de sedimentos são: a carga sólida afluente, a eficiência de retenção do reservatório (que é a razão entre a quantidade de sedimento retido e a quantidade de sedimento total que entra no reservatório), a densidade e o volume dos sedimentos assoreados.

Vanoni (1977) e Lane (1955) também acrescentam que a distribuição e a deposição de sedimentos em reservatórios dependem da geometria e do modo de operação do reservatório, da declividade de escoamento, das características e propriedades dos sedimentos e das águas, dentre outros.

Asthana e Nigam (1980) também citam que diversos fatores interferem na distribuição e nos depósitos de sedimentos nos reservatórios. Segundo os autores, entre estes fatores destacam: o modo de operação do reservatório, a quantidade, o tamanho e o tipo de sedimento transportado, o formato do reservatório, a vegetação e o deflúvio afluente e efluente ao reservatório. 
Várias técnicas e métodos são encontrados na literatura para medição de assoreamento de reservatórios.

De acordo com Borland e Miller (1958 5 apud MAIA, 2006), o método de incremento de área, desenvolvido por Cristofano (sem data $)^{6}$, foi a primeira metodologia estritamente matemática criada para o cálculo da redução de volume de reservatórios. Ainda segundo os autores, o método permitia realizar estimativas da altura dos sedimentos no reservatório em um período de tempo pré-determinado, sendo possível, desta forma, determinar uma nova curva cota $v s$. área $v s$. volume para avaliação da variação do volume do reservatório devido ao assoreamento.

Quanto à questão de estimativas preliminares de assoreamento em reservatórios, merece destaque as técnicas desenvolvidas experimentalmente, baseadas no cálculo do percentual de retenção de sedimentos do reservatório e nas curvas apresentadas por Churchill $(1948)^{7}$ e Brune $(1953)^{8}$.

Ainda segundo Koelzer e Lara (1958 ${ }^{9}$ apud MAIA, 2006), o cálculo do volume de sedimento em um reservatório consiste em três etapas: “[...] estimar o sedimento afluente ao reservatório, estimar o sedimento afluente que permaneceu no reservatório e converter o sedimento retido de unidade de peso para unidade de volume.”. Da mesma forma, Coiado (2001) apresenta que para estimar o volume assoreado no reservatório são necessárias as seguintes informações: descarga sólida que adentra o reservatório, eficiência de retenção do reservatório, peso específico e distribuição dos sedimentos depositados.

\footnotetext{
${ }^{5}$ BORLAND, W.M.; MILLER, C.R. (1958). Distribution of Sediment in Large Reservoirs. Journal of the Hydraulics Division, ASCE, v.84, pp.1587-1 a 1587-18.

${ }^{6}$ CRISTOFANO, E.A. (sem data). Former Hydraulic Engineer. Project Office. Bureau of Reclamation, Novo Mexico.

${ }^{7}$ CHURCHILL, M.A. (1948). Discussion of “Analysis and use of reservoir sedimentation data" by L.C. Gottschalk, Proc., Federal Inter-Agency Sedimentation Conference, Washington, p. 139-140.

${ }^{8}$ BRUNE, G.M. (1953). Trap Efficiency of Reservoirs. Trans. American Geophysical Union. vol. 34, n.3.

${ }^{9}$ KOELZER, V.A.; LARA, J.M. (1958). Densities and compaction rates of deposited sediment. Journal of Hydraulic Division, v. 84.
} 
A distribuição dos sedimentos em reservatório não é uniforme (MAHMOOD, 1987; CARVALHO et al., 2000b) e pode dar origem, basicamente, a três tipos de depósitos: depósito de remanso (Backwater deposit), delta (delta) e depósito de fundo (Bottom-set deposit) (VANONI, 1977; CARVALHO, 2008).

A Figura 1 apresenta a localização destes depósitos e os principais problemas ocasionados por eles.

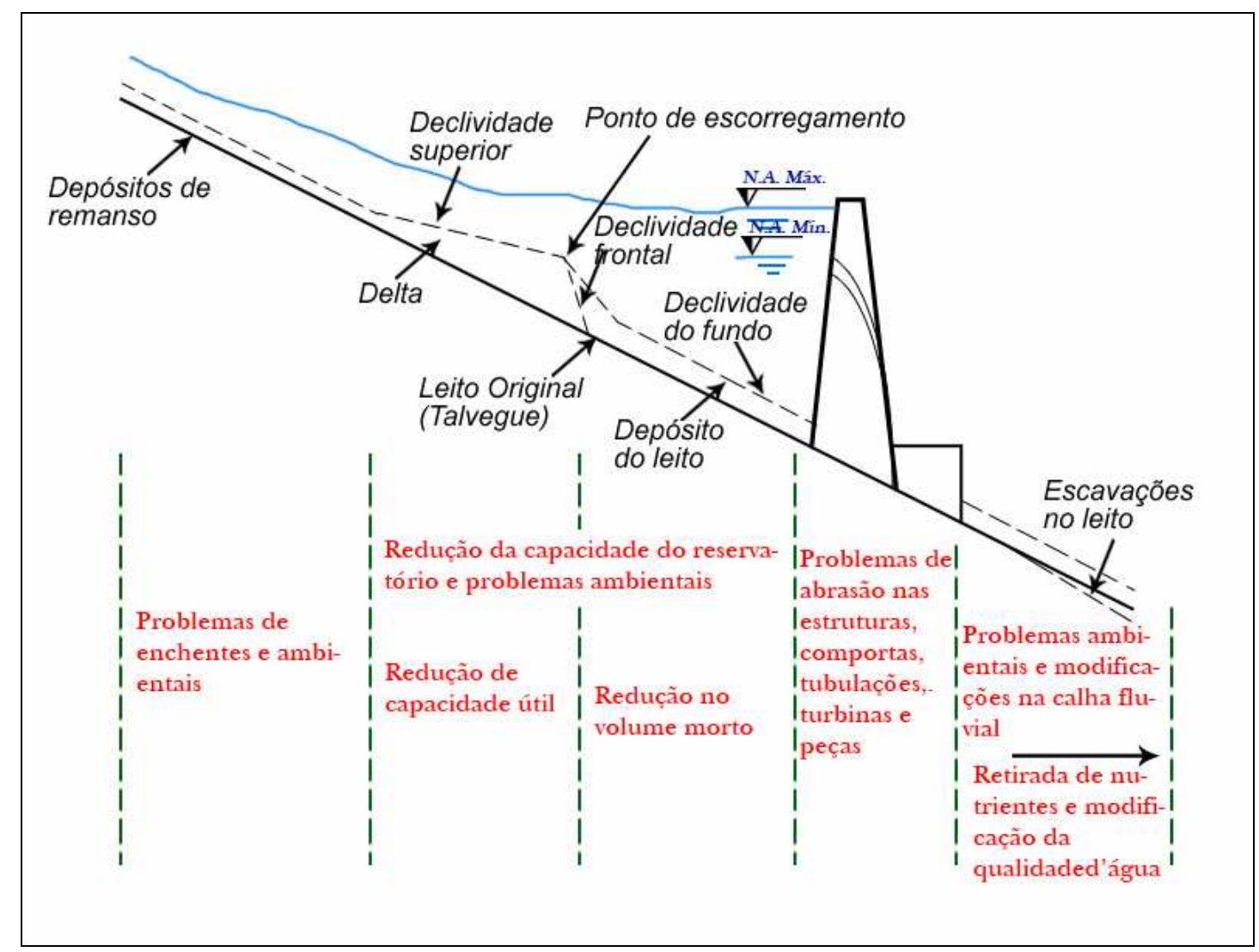

Figura 1. Formação de depósitos de sedimentos nos reservatórios e seus principais problemas.

Fonte: Carvalho (2008).

Nos depósitos de remanso (denominação que faz referência ao fenômeno hidráulico), localizados na entrada do reservatório, são encontrados, geralmente, sedimentos de granulometria maior - como areia (VANONI, 1977; CARVALHO, 2008). Estes depósitos não provocam necessariamente a perda da capacidade útil do reservatório, porém podem intensificar problemas causados pelas enchentes a montante do reservatório (COIADO, 2001). 
Os deltas são formados no interior do reservatório, conforme demonstrado na Figura 1, por sedimentos de diversas granulometrias, e têm como principal consequência a redução gradativa do volume útil do reservatório. Além disso, os depósitos de remanso e os deltas também afetam a navegação com a redução da profundidade dos cursos d'água.

Segundo Carvalho e Lôu (1986), através de estudos e pesquisas realizados em diversos reservatórios, pôde-se constatar que uma grande porcentagem do volume de sedimentos se deposita na região de delta, interferindo, principalmente, na regularização das vazões dos cursos d'água e na geração de energia.

Por sua vez, os depósitos de fundo ou leito, formados, geralmente, por materiais mais finos como silte e argila, ficam localizados nos trechos mais baixos do reservatório, próximo à barragem, sendo responsáveis pelo assoreamento do volume morto (VANONI, 1977; CARVALHO, 2008). Segundo Coiado (2001), estes depósitos também podem impossibilitar o funcionamento de comportas de órgãos de adução ou de descarga de obras hidráulicas.

Além dos tipos de depósitos descritos acima, também podem-se encontrar em reservatórios os depósitos de margem (overbank), originados pela deposição dos sedimentos transportados pelas ondas de água e pelo vento, e os depósitos de várzea ou de planície de inundação que são gerados pelas enchentes e ocorrem ao longos dos cursos de água e reservatórios (VANONI, 1977; CARVALHO et al., 2000b).

Neste sentido, o assoreamento de reservatórios tem provocado diversos problemas econômicos, sociais e ambientais. E conforme Morris e Fan (1997) afirmam, com o passar do tempo, os problemas com o assoreamento se tornam mais severos e mais difíceis de serem controlados.

Embora os estudos relativos aos problemas de assoreamento de reservatórios sejam uma preocupação antiga, as pesquisas sobre o assunto apareceram com maior frequência na 
literatura internacional após 1930, através dos trabalhos de Fiock ${ }^{10}$ (1934), Grover e Howards $^{11}$ (1938) e Eakin ${ }^{12}$ (1939) (COELHO, 1993).

No Brasil, no entanto, somente a partir de 1980 as pesquisas sobre assoreamento ganharam maior ênfase, com os trabalhos de Poçano et al. (1981), Gimenez et al. (1981) e Carlstron Filho et al. (1981) que apresentaram métodos de análises de assoreamento para os reservatórios de Capivari (PR), Passo Real e Ernestina (RS), respectivamente, desenvolvidos pelo Instituto de Pesquisas Tecnológicas do Estado de São Paulo (IPT) em convênio com a Eletrobrás (CABRAL, 2005).

Um dos trabalhos mais importantes relativos ao assoreamento de reservatório é um estudo realizado pelo Banco Mundial apresentado em MAHMOOD (1987 apud CARVALHO et al., 2000b), o qual cita que a vida útil média dos reservatórios no mundo decresceu de 100 para 22 anos e que a perda média anual de volume dos reservatórios, devido ao assoreamento, era de $1 \%$ variando de um local para o outro.

Mais especificamente, com relação aos reservatórios brasileiros, um estudo realizado pelo Instituto de Pesquisas Hidráulicas - IPH em 1994, para a Eletrobrás, concluiu que a perda anual de volume de armazenamento dos reservatórios do país era de aproximadamente 0,5\% (CARVALHO, 2008).

São diversos os estudos apresentados no Brasil e no mundo que abordam a questão do assoreamento de reservatório.

Oliveira (1984 ${ }^{13}$ apud VILLELA e PONCE, 1986), apresentou um estudo sobre os reservatórios de abastecimento e recreação nos Estados Unidos, nele o autor mostrava que devido ao assoreamento, $21 \%$ dos reservatórios teriam uma vida útil menor que 50 anos,

\footnotetext{
${ }^{10}$ FIOCK, L.R. (1934). Records of silt carried by the Rio Grande and its acumulation in elephant butte reservoir. American Geophys. Union Trans, v15, p. 468-473.

${ }^{11}$ GROVER, H.G; HOWARDS, C.S. (1938). The passage of turbid water throug lake mead. Tran ASCE, 103, p. 720-736.

${ }^{12}$ EAKIN, H.M. (1939). Silting of reservoirs. Washington DC: United States Department of Agriculture. Tech Bulletin, 524, p. 90-167.

${ }^{13}$ OLIVEIRA, C.N. (1984). Curso sobre Estudo do Transporte Sólido nos Cursos d'água e Assoreamento de Reservatórios de Uso Múltiplo. Ilha Solteira, SP, v. 2.
} 
outros $25 \%$ durariam de 50 a 100 anos e apenas $54 \%$ dos reservatórios teriam condição de operar por mais 100 anos. Fato este também evidenciado por Linsley e Franzini (1972) que apresentou um estudo realizado no reservatório de abastecimento de água do Rio Salomon (EUA) que teve todo o seu volume assoreado no seu primeiro ano de operação.

Outro exemplo de reservatório assoreado foi apresentado por Paiva (1993) que citou o caso da Barragem de Elephant Butte (Novo México) que tinha sido construída em 1916 e em 24 anos de operação havia perdido 600 milhões de $\mathrm{m}^{3}$ do seu volume de armazenamento.

Goldsmith e Hildyard (1984), em referência ao United States Committee on Large Dams - USCOLD (1982) ${ }^{14}$, também destacam alguns estudos sobre assoreamento precoce de reservatórios. Os autores citam dois casos de reservatório chineses onde o Reservatório de Sanmenxia, que foi concluído em 1960, teve de ser desativado em 1964 devido ao seu assoreamento prematuro e o Reservatório de Laoying que foi assoreado antes mesmo da construção da sua barragem ser concluída.

Remenieras e Braudeau (1951 ${ }^{15}$ apud BUFON, 2006), analisaram a questão do assoreamento em alguns reservatórios da França e dentre os locais estudados pelos autores destaca-se o caso do Reservatório de Motty que possuía um volume de $1.750 .000 \mathrm{~m}^{3}$ e foi completamente assoreado em 2 anos.

Valera e Izquierdo (1984) apresentaram em seu estudo alguns problemas decorrentes do assoreamento do Reservatório de Anchicaya (Colômbia) e suas possíveis soluções, tendo em vista que o reservatório tinha perdido cerca de $60 \%$ da sua capacidade inicial de armazenamento durante o curto período de 4 anos (1958 a 1962).

No Haiti, a Barragem Pelegri (no Rio Artibonite) que foi concluída em 1956 e foi planejada para operar durante 50 anos, como parte de um plano para fornecer irrigação para

\footnotetext{
${ }^{14}$ USCOLD - United States Committee on Large Dams. (1982). Newsletter $\mathbf{n}^{\mathbf{0}} . \mathbf{6 9}$, November, p.15.

15 REMENIERAS, G.; BRAUDEAU, G. (1951). Quelques observations sur l'alluvionnement dans les reservoirs français. In: INTERNATIONAL CONGRESS ON LARGE DAMS, 4th, New Delhi: ICOLD. p. 197-236.
} 
região, foi desativada em 1986 depois de apenas 30 anos de operação (GOLDSMITH E HILDYARD, 1984).

Outro estudo interessante que aborda a questão do assoreamento em reservatório é apresentado por Chanson e James (1998) em que os autores analisaram quatro reservatórios na Austrália que tiveram uma vida útil menor que 25 anos. Os autores puderam concluir que diversos fatores influenciaram para este problema como: o clima, a produção e o transporte de sedimento nas regiões em torno dos reservatórios, o uso do solo e até mesmo erros de projeto e de seleção do local para construção das barragens. Além deste estudo, estes mesmos autores apresentaram também outros trabalhos que abordam a questão de sedimentação nos reservatórios australianos como Chanson $(1998)^{16}$ e Chanson e James (1999) ${ }^{17}$.

No Brasil também se encontram diversos estudos relacionados à questão do assoreamento precoce de reservatórios.

Paiva et al. (1998) realizaram um estudo no Reservatório de Vacacaí-Mirim (RS), que teve sua construção iniciada em 1961 e seu enchimento em 1972, e puderam constatar que durante o período de 1972 a 1997 houve uma redução de aproximadamente 23\% na capacidade de armazenamento do reservatório ao longo de 25 anos de operação. Posteriormente Dill (2002) realizou outro estudo no local e através de levantamentos batimétricos realizados em 2001 constatou que a redução do volume do reservatório era de $29,45 \%$ com relação ao seu volume original.

Vilhena et al. (2003) estudaram o Reservatório de Funil (RJ) e constatam que o volume do reservatório em 1969 que era de 82,19 milhões de $\mathrm{m}^{3}$ foi reduzido em 1992 para 63,74 milhões de $\mathrm{m}^{3}$, o que representava uma perda de capacidade de armazenamento de $22,93 \%$ para o período estudado.

\footnotetext{
${ }^{16}$ CHANSON, H. (1998). Extreme reservoir sedimentation in Australia: a review. International J. of Sediment Research. 13(3), p. 55-62.

${ }^{17}$ CHANSON, H; JAMES, P. (1999). Siltation of Australian reservoirs: some observations and dam safety implications. In: IAHR Congress, 28, Session B5. Graz, Áustria.
} 
Machado et al. (1999) apresentaram um estudo relativo ao assoreamento do Reservatório do Rio Santo Anastácio que abastece a cidade de Presidente Prudente (SP) e que teve seu volume reduzido em 13,42\% entre 1993 e 1998, mudando de $1.962 .000 \mathrm{~m}^{3}$ para $1.698 .515 \mathrm{~m}^{3}$.

Cabe destacar que uma grande parte dos estudos de sedimentação em reservatórios relaciona este problema com suas eventuais consequências na operação e geração das usinas hidrelétricas, demonstrando que as concessionárias de energia elétrica estão cada vez mais preocupadas com estas questões, pois, na maioria das vezes, a diminuição da capacidade de armazenamento de água nos reservatórios implica na redução gradual de geração de energia elétrica e, consequentemente, em perdas financeiras.

Almeida e Carvalho (1993) relatam que uma das paralisações da UHE Funil (BA) devido ao assoreamento do reservatório, ocorrida no período de janeiro de 1992 a março de 1993, acarretou para a Companhia Hidro Elétrica do São Francisco - CHESF, uma perda no faturamento na ordem de US\$ 1.200.000,00, além do custo para dragagem de sedimento do reservatório $\left(32.880 \mathrm{~m}^{3}\right)$ e dos condutos forçados $\left(1.000 \mathrm{~m}^{3}\right)$ que giraram em torno de US\$ $220.000,00$.

Outro exemplo típico de assoreamento precoce de reservatório hidrelétrico é o caso da UHE de Mascarenhas localizada no Rio Doce (ES) e inaugurada em 1974, que teve o seu reservatório planejado para regularizar uma vazão de $600 \mathrm{~m}^{3} / \mathrm{s}$ e gerar $120 \mathrm{MW}$, porém, dispunha na maior parte do tempo, de uma vazão de $400 \mathrm{~m}^{3} / \mathrm{s}$ e em períodos de estiagem este valor se reduzia a $190 \mathrm{~m}^{3} / \mathrm{s}$. A bacia hidrográfica onde o reservatório se encontrava produzia uma grande quantidade de sedimentos acarretando no assoreamento do reservatório e exigindo limpezas periódicas de elevados custos (CARVALHO e LÔU, 1986).

Os mesmos autores também citam os estudos realizados pelo Instituto Nacional de Pesquisas Espaciais e pela Empresa Brasileira de Pesquisas Agropecuárias, onde o 
Reservatório de Sobradinho (BA) apresentava redução significativa da sua vida útil devido ao assoreamento acelerado da região. Segundo as empresas, o reservatório estaria completamente assoreado em um período de 80 anos, fato este que contrastava com estudos realizados pela CHESF que havia calculado que em um período de 100 anos o assoreamento atingiria apenas $5 \%$ da capacidade do reservatório.

Paiva (1993) também apresenta uma interessante revisão bibliográfica sobre a influência da sedimentação na produção de energia de alguns reservatórios.

O autor apresenta um estudo de caso na Usina de Taquaraçu (MG), construída em 1935 e que teve uma grande perda de capacidade de armazenamento ao decorrer dos anos de operação. O reservatório que inicialmente tinha capacidade de armazenamento de 2.200 .000 $\mathrm{m}^{3}$ passou a $700.000 \mathrm{~m}^{3}$ em 1992, ou seja, perda de $70 \%$ de sua capacidade. Como consequência, a produção de energia que era de $20.000 .000 \mathrm{kWh} /$ ano em 1935, diminuiu para 12.000.000 kWh/ano em 1992 (40\% da capacidade produtiva da central). Esta usina era utilizada para abastecimento energético da Companhia Siderurgia Belgo-Mineira e, segundo o autor, o custo da energia não produzida em 1992 apresentou-se entre 400 mil a 500 mil dólares. Devido a estas perdas a empresa precisou comprar energia suplementar para atender sua demanda, arcado com custos na ordem de 1,5 milhões a 1,7 milhões de dólares.

A Usina da Brecha (MG) é outro exemplo de reservatório assoreado, sua capacidade de armazenamento inicial que era de $2.000 .000 \mathrm{~m}^{3}$ em 1958 , teve uma redução de $800.000 \mathrm{~m}^{3}$ (40\%) em 1992, passando para $1.200 .000 \mathrm{~m}^{3}$. Consequentemente houve uma diminuição significativa na geração de energia e a quantidade de energia não produzida em 1992 era de 9.000.000 kWh/ano o que representava uma perda na ordem de 400 mil a 500 mil dólares (PAIVA, 1993). 


\subsection{Medidas preventivas e corretivas para o controle do assoreamento de reservatórios}

Para evitar ou amenizar alguns problemas destacados nos capítulos anteriores, tornase necessária a adoção de medidas preventivas e corretivas contra o processo de assoreamento de reservatórios.

Como pôde-se verificar anteriormente, o assoreamento de reservatório proporciona problemas em diversas áreas, causando, em alguns casos, grandes custos ou até mesmo consequências irreversíveis às obras hidráulicas.

Apesar do assoreamento em reservatórios ser um processo inevitável, pode-se evitar ou minimizar grande parte dos problemas causados pela deposição de sedimento e se ter um controle do sedimento afluente ao reservatório através destas medidas.

Conforme Poçano et al. (1981) apresentam, as medidas preventivas e corretivas requerem estudos específicos que considerem a dinâmica dos sedimentos desde suas áreas fontes até os locais de deposição.

As medidas preventivas são empregadas para evitar a produção dos sedimentos e que o transporte dos mesmos chegue até os cursos d'água evitando a formação dos depósitos de sedimentos nos reservatórios. Já as medidas corretivas têm como objetivo amenizar os efeitos causados pelo sedimento quando estes já estão depositados no reservatório.

Conforme Carvalho (2008) cita, as medidas preventivas são mais eficazes e econômicas do que as medidas corretivas que são utilizadas para amenizar prejuízos materiais e financeiros ocasionados pelos depósitos de sedimentos.

Apesar das medidas preventivas contemplarem inúmeras alternativas para prevenção e mitigação dos depósitos de sedimentos, em diversos países (dentre eles o Brasil) são raros os projetos que apresentam bons estudos e ações preventivas para este problema. 
Umas das principais medidas preventivas quando se trata do assoreamento de reservatórios é o estudo e a seleção do melhor local para construção da barragem, pois sua construção tem grande influência na taxa de assoreamento do reservatório. Desse modo, devem-se privilegiar locais com menores índices de produção de sedimentos.

Essa questão merece atenção principalmente com relação às novas e polêmicas usinas que estão sendo construídas no Rio Madeira (UHE Jirau e UHE Santo Antônio). O Rio Madeira apresenta altas concentrações de sedimentos em suspensão e devido às características da bacia hidrográfica onde se localiza, qualquer empreendimento construído neste rio exige grande quantidade de estudos para avaliar qual será sua influência no transporte de sedimentos neste curso d'água.

As discussões com relação às construções destas usinas decorrem justamente com relação aos estudos que foram realizados para validação da implantação das mesmas na região e aos seus possíveis impactos. Diversos pesquisadores questionam os estudos e resultados obtidos nos projetos destes empreendimentos quanto aos problemas de assoreamento dos reservatórios e do transporte de sedimentos.

Enquanto os órgãos públicos e as empresas que desenvolveram estes estudos defendem que haverá um assoreamento nos primeiros anos de operação das usinas, mas que após um curto período de tempo ocorrerá um equilíbrio hidrodinâmico entre a quantidade de sedimentos que chegam aos reservatórios e que saem pelas estruturas das usinas, outros profissionais e pesquisadores citam que a grande quantidade de sedimento que é gerada nesta bacia, deverá prejudicar significativamente a operação destas usinas. Outro fato que é destacado pelos profissionais que são contra as construções destas usinas neste local é que, além dos sedimentos, o Rio Madeira também apresenta um elevado transporte de material flutuante como galhos, folhas e troncos de árvores que são uma preocupação adicional para construção destes empreendimentos neste curso d'água. 
O volume do reservatório destinado aos sedimentos e os seus locais de deposição também são importantes medidas preventivas que devem ser destacadas, pois com o estudo e a construção de locais maiores para deposição de sedimentos, pode-se postergar o início de alguns problemas causados pelos sedimentos. Conforme Ponce (1986) destaca, o volume morto (espaço destinado ao acúmulo de sedimento) não é uma solução para o problema de assoreamento, mas apenas uma alternativa para retardar os problemas originados devido a estes depósitos.

Outra medida preventiva que merece destaque é o controle das fontes de produção de sedimentos, ou seja, o controle da erosão da bacia hidrográfica onde o curso d'água está inserido. Neste ponto, o uso e a ocupação do solo estão intimamente relacionados aos processos erosivos, sendo exigidas ações de ordem técnica, social, financeira e política para o entendimento e controle destes processos.

Apesar da legislação ambiental vigente atualmente, como o Código Florestal - Lei Federal $\mathrm{n}^{\circ} 4.771$ (BRASIL, 1965), estabelecer a manutenção de áreas protegidas com a função de preservar os recursos hídricos, o meio ambiente local, e a biodiversidade, entre outros, é possível observar atualmente que o uso e a ocupação dos solos próximos aos reservatórios, na maioria das vezes, são destinados a práticas inadequadas como agricultura e pecuária. Estas ações, geralmente favorecem os processos erosivos e intensificam a deposição de sedimentos no reservatório, prejudicando a vida útil e operação dos mesmos.

Além da falta de cumprimento da legislação vigente, algumas situações demonstram que a proteção dos recursos hídricos e do meio ambiente podem estar ainda mais comprometidas. As propostas de alteração do Código Florestal que vêm sendo discutidas atualmente reduzem significativamente as áreas de preservação das margens dos cursos d'água, modificam as regras da reserva legal (porcentagem de área que deve ser preservada dentro de toda propriedade rural) e isentam proprietários que realizaram desmatamentos até 
2008, entre outros. Estas alterações, se aprovadas, causarão significativos impactos na preservação dos recursos hídricos, na conservação da fauna e flora local e nos solos das bacias hidrográficas.

Paiva et al. (2001) citam que o estudo e a compreensão dos processos de erosão do solo e a quantificação das suas perdas, são de grande importância para a elaboração de medidas que visem minimizar os efeitos negativos decorrentes da produção dos sedimentos.

Chow (in GOTTSCHALK, 1964), cita que as medidas para proteção, tratamento e conservação dos solos da bacia hidrográfica apresentam-se como as melhores alternativas econômicas para a diminuição das taxas de erosão.

Muller (1995) também enfatiza que o controle da erosão da bacia hidrográfica é a medida preventiva mais eficiente para reduzir o assoreamento dos reservatórios. Porém, o autor destaca dois fatores que dificultam a implementação destas medidas, principalmente quando relacionados aos reservatórios hidrelétricos: os resultados ambientais e energéticos serem obtidos a médio e longo prazo e as terras ao redor do reservatório não serem, na maioria das vezes, de propriedade das concessionárias de energia.

O controle da erosão pode ser realizado a partir da adoção de práticas conservacionistas em áreas agrícolas como: a cultura em faixa, o controle de voçorocas, os sistemas de preparo e a rotação de culturas.

Segundo estimativas da GEO Brasil apresentado pela Agência Nacional de Águas (2010), estima-se que somente no Brasil, as perdas de nutrientes carreados pela erosão tragam um prejuízo na ordem de R \$ 7,9 bilhões/ano. Quando somado a este valor o "efeito da erosão na depreciação da terra e outros custos tais como conservação de estradas, tratamento de água e redução da vida útil do reservatório", este prejuízo alcançaria $\mathrm{R} \$ 13,3$ bilhões/ano (SCARPINELLA e MAUAD, 2010). 
Guerra (1994) destaca que a cobertura vegetal dos solos é uma das ações mais importantes na proteção dos mesmos contra os processos erosivos, pois reduz os impactos das gotas de chuva sobre o terreno, além de proporcionar uma maior estabilidade aos solos.

Neste sentido, a manutenção das florestas, o reflorestamento, a conservação e o plantio de matas ciliares nas margens dos reservatórios, destacam-se como importantes ações preventivas a produção e ao depósito de sedimentos.

Blackwelder (in GOLDSMITH e HILDYARD, 1984) destaca a importância do reflorestamento das áreas de drenagem dos rios represados. Segundo o pesquisador, este reflorestamento deve ser realizado com espécies nativas da região, como forma de reconstituir, tanto quanto possível, as florestas nativas originais que existiam antes do represamento das águas.

Campos e Landgraf (2001) citam que a presença de mata nativa ao longo dos cursos d'água é importante, pois servem como barreira para o escoamento da água das enxurradas e acarretam em uma diminuição da velocidade destas correntes d'água, possibilitando que as águas sejam absorvidas pelas plantas e aquíferos subterrâneos, e contribuindo, consequentemente, para evitar o transporte de sedimento aos cursos d'água.

O plantio de mata ciliar ao redor dos reservatórios vem recebendo uma atenção especial das empresas relacionadas ao setor de geração de energia, principalmente devido aos problemas que o assoreamento tem causado para as usinas hidrelétricas.

Muitas empresas concessionárias de energia vêm percebendo que, a partir de iniciativas voltadas ao meio ambiente, elas conseguem uma melhor eficiência energética e que seus gastos com programas ambientais são relativamente baixos quando comparados aos custos decorrentes de problemas ambientais como o assoreamento.

Além destes fatos, as concessionárias perceberam que a recuperação das áreas do entorno dos seus reservatórios também podem render lucros com a comercialização de 
créditos de carbono dentro do Protocolo de Quioto, por meio do Mecanismo de Desenvolvimento Limpo (MDL). Este mecanismo aceita que países desenvolvidos continuem com suas emissões de gases de efeito estufa desde que adquiram o "direito de emissão". Este "direito" pode ser obtido por meio de apoio a projetos, realizados em países em desenvolvimento, que absorvam o carbono atmosférico, como é o caso do plantio das matas ciliares em reservatórios hidrelétricos (SCARPINELLA e MAUAD, 2010).

Outras medidas preventivas que merecem destaque são as construções de estruturas para contenção dos sedimentos, que evitam que os mesmos cheguem aos corpos hídricos, como: pequenas barragens a montante, bacias de decantação e condutos para desvio de sedimentos (sediment bypassing).

As medidas corretivas são adotadas quando os depósitos de sedimentos influenciam ou comprometem a operação ou função dos reservatórios, ou as estruturas e as obras hidráulicas. Segundo o International Commission on Large Dams - ICOLD (1989), estas medidas visam remediar os problemas causados pelos depósitos de sedimentos quando estes afetam a vida útil do empreendimento.

Assim, as medidas corretivas visam minimizar os efeitos causados pelo assoreamento, com a remoção de sedimentos por meio de descarregadores de fundo, dragagem de sedimentos, alteamento da barragem, entre outros.

A retirada de sedimentos pode ser realizada por estruturas hidráulicas, como a descarga ou comporta de fundo, que são importantes ferramentas adotadas para reduzir a quantidade de sedimento depositado.

Yoon (1992) cita que a remoção de sedimentos por escoamento através dos descarregadores de fundo pode ser classificado em: sluicing e flushing. De acordo com o autor, o primeiro método consiste na liberação do sedimento antes que eles se depositem e tem sido bastante empregado nos reservatórios da China, mostrando ser um eficiente meio 
para controle de assoreamento. Já o flushing consiste na remoção dos sedimentos que já foram depositados e pode ser empregado com ou sem rebaixamento do nível d'água do reservatório.

Muitos autores defendem a manutenção do fluxo sedimentar para jusante através da transposição de sedimentos, justificando que esta preocupação deveria ser comparada com a manutenção da descarga hídrica efluente que é utilizada para não comprometer as atividades desenvolvidas a jusante da barragem.

Porém, cabe destacar que o uso dos descarregadores de fundo não é aconselhável para todos os tipos de reservatórios, pois sua utilização demanda uma grande quantidade de água que é escoada junto com os sedimentos. Além disso, a utilização destes descarregadores exige estudos quanto à localização destas estruturas e a quantidade de sedimento que será liberada para não causar problemas ambientais a jusante conforme apresentado na Resolução do Conselho Nacional do Meio Ambiente - CONAMA n 344, de 25 de março de 2004 (BRASIL, 2004).

Outra medida corretiva que pode ser adotada é a dragagem de sedimentos. Esta medida consiste na remoção dos sedimentos depositados por meios mecânicos. A dragagem geralmente é utilizada em situações extremas, por exemplo, quando os sedimentos estão alcançando a tomada d'água das centrais hidrelétricas. Esta técnica tem como vantagem a possível utilização dos materiais que são dragados, principalmente areia, para obras na construção civil, o que pode proporcionar redução nos custos deste processo com a venda destes materiais.

Cabe destacar, no entanto, que a comercialização do material dragado está sujeita a análise e tratamento do material coletado e ao fim que os mesmos se destinam.

No entanto, é importante salientar que a dragagem também apresenta algumas desvantagens, como: exigir o uso de energia externa para remoção dos sedimentos, demandar elevada quantidade de água e alto custo para realização. 
Raudkivi (1993) cita que a demanda de água exigida em alguns processos de dragagem podem atingir uma razão de 4:1 de água em relação ao sedimento, fato este que torna a dragagem uma alternativa inviável para alguns reservatórios.

Quanto ao custo para realização da dragagem, Carvalho (2008) cita que pode variar de US\$1,00 a US\$15,00 por $\mathrm{m}^{3}$ dragado, pois depende da situação do local, da localização dos sedimentos, do destino do material dragado, entre outros. Deste modo, o autor aconselha o uso da dragagem somente quando os outros processos não puderem ser utilizados.

Reformas nas estruturas hidráulicas e barragem também são alternativas utilizadas para amenizar os efeitos do assoreamento nos reservatórios. Como exemplo destas medidas pode-se citar a realocação de estruturas, como a tomada de água de centrais hidrelétricas, que pode ser uma opção interessante em casos onde os sedimentos já estão próximos de alcançar estas estruturas (MAIA e VILLELA, 2006).

O alteamento (elevação) da barragem também pode ser adotado como forma de recuperação do volume de água perdido pelos depósitos de sedimentos. Porém, cabe ressaltar que, esta reforma exige maiores custos e estudos detalhados, sendo indicado apenas quando for possível aumentar a área do reservatório com reduzidos custos de desapropriação de terrenos e impactos sociais e ambientais (CARVALHO, 2008).

Em suma, conforme Shen e Lai (1996) afirmam, o assoreamento pode ser reduzido ou controlado por meio de três medidas básicas: redução da quantidade de sedimentos que entram no reservatório através dos processos erosivos da bacia; remoção dos sedimentos, por ações mecânicas (como a dragagem) e; escoamento dos sedimentos que chegam ao reservatório por estruturas hidráulicas como a descarga de fundo.

Carvalho (in BRASIL, 1984) também resume os métodos de controle de sedimentação em reservatórios, em seis classes distintas: seleção do local, projeto do 
reservatório, controle de sedimentos afluentes, controle da deposição de sedimentos, remoção dos depósitos e controle de erosão da bacia.

Portanto, como é possível observar, as medidas preventivas e corretivas para o controle do assoreamento podem ser adotadas desde o projeto do reservatório até a sua operação, sendo que a escolha, aplicação e avaliação dos resultados obtidos através da implantação de cada uma destas medidas, dependem de um completo entendimento dos processos fundamentais de sedimentação e dos princípios envolvidos nestes processos (CARVALHO, 2008). 


\subsection{Levantamentos batimétricos}

Um dos métodos empregados para a avaliação e monitoramento dos volumes de água e da quantificação dos sedimentos depositados nos corpos hídricos é a batimetria, que consiste em medir e representar relevos de áreas submersas, como mares, rios, lagos e reservatórios.

Os levantamentos batimétricos podem ser realizados através de diferentes métodos, dentre os quais é possível destacar os levantamentos: a vau, com guincho hidrométrico e com sondas acústicas. A escolha desses métodos e dos instrumentos que serão utilizados depende, na maioria das vezes, da disponibilidade dos dados, dos objetivos do estudo, da dimensão do reservatório e do grau de precisão desejada.

Segundo Santos et al. (2001), o procedimento a vau é empregado, geralmente, em rios pequenos (com profundidades inferiores a 1 metro e velocidade abaixo de $1 \mathrm{~m} / \mathrm{s}$ ) e consiste na medição da profundidade com uma mira ou régua graduada. A batimetria com guincho hidrométrico, um dos métodos mais empregados no Brasil, é utilizada nas mais diferentes situações. A profundidade máxima medida pelo instrumento depende da velocidade do curso d'água, porém, geralmente, recomenda-se que a profundidade não seja maior do que 10 metros. E a ecobatimetria (realizada por sondas acústicas) é baseada na medição da profundidade da água através da estimativa do tempo para que as ondas emitidas pelo aparelho sejam refletidas e retornem ao mesmo. A faixa de operação destes equipamentos depende do modelo utilizado, mas normalmente, é de 0,5 a 100 metros de profundidade.

Carvalho et al. (2000b) apresentam na Tabela 1 um resumo dos principais métodos e equipamentos utilizados em levantamentos topobatimétricos de rios e reservatórios. 
Tabela 1. Principais métodos utilizados em levantamentos topobatimétricos de rios e reservatórios.

\begin{tabular}{|c|c|c|c|}
\hline \multicolumn{2}{|c|}{ Métodos } & \multirow[b]{2}{*}{ Utilização } & \multirow[b]{2}{*}{ Observação } \\
\hline Medida da distância & $\begin{array}{c}\text { Medida da } \\
\text { profundidade }\end{array}$ & & \\
\hline Trena & $\begin{array}{l}\text { Régua, escala } \\
\text { graduada }\end{array}$ & $\begin{array}{lrr}\text { Rios ou braços de } & \text { de } \\
\text { lagos estreitos } & \text { e } \\
\text { rasos } & & \end{array}$ & $\begin{array}{l}\text { Medição a vau ou até } 2 \\
\text { metros }\end{array}$ \\
\hline Cabo de aço & Sonda ou lastro & $\begin{array}{l}\text { Rios ou braços de } \\
\text { lagos rasos ou } \\
\text { profundos, larguras } \\
\text { até } 300 \text { metros }\end{array}$ & Medição a \\
\hline Sext & $\begin{array}{ll}\text { Sonda } & \text { ou } \\
\text { ecobatímetro } & \text { de } \\
\text { leitura direta } & \end{array}$ & $\begin{array}{l}\text { Rios ou braços de } \\
\text { lagos rasos ou } \\
\text { profundos, larguras } \\
\text { até } 2 \text { quilômetros }\end{array}$ & $\begin{array}{l}\text { Instalar linha básica na } \\
\text { margem de tal forma a } \\
\text { que sejam lidos ângulos } \\
\text { maiores que } 30^{\circ}\end{array}$ \\
\hline Teodolitos (2 ou 3 ) & $\begin{array}{ll}\text { Ecobatímetro } & \\
\text { digital } & \text { ou } \\
\text { analógico } & \end{array}$ & $\begin{array}{l}\text { Rios ou braços de } \\
\text { lagos rasos ou } \\
\text { profundos, larguras } \\
\text { até } 2 \text { quilômetros }\end{array}$ & $\begin{array}{l}\text { Instalar linha topográfica } \\
\text { na margem de tal forma } \\
\text { a que sejam lidos } \\
\text { ângulos maiores que } 30^{\circ}\end{array}$ \\
\hline $\begin{array}{l}\text { Distanciometros ou } \\
\text { Estação total }\end{array}$ & $\begin{array}{ll}\text { Ecobatímetro } & \\
\text { digital } & \text { ou } \\
\text { analógico } & \\
\end{array}$ & $\begin{array}{l}\text { Seções } \text { transversais } \\
\text { até } 10 \text { quilômetros } \\
\text { de largura }\end{array}$ & $\begin{array}{l}\text { Pode ser gravado em } \\
\text { meio magnético para uso } \\
\text { em plotter }\end{array}$ \\
\hline $\begin{array}{ll}\text { Sistema eletrônico } & \text { de } \\
\text { posicionamento } & \\
\text { Trisponder } & \text { ou } \\
\text { Motorola } & \\
\end{array}$ & $\begin{array}{ll}\text { Ecobatímetro } & \\
\text { digital } & \text { ou } \\
\text { analógico } & \end{array}$ & $\begin{array}{l}\text { Seções transversais } \\
\text { até } 50 \text { quilômetros }\end{array}$ & $\begin{array}{l}\text { Gravado em meio } \\
\text { magnético para uso em } \\
\text { plotter }\end{array}$ \\
\hline $\begin{array}{lr}\text { DGPS - } & \text { (Differencial } \\
\text { Global } & \text { Positioning } \\
\text { System }) & \\
\end{array}$ & $\begin{array}{l}\text { Ecobatímetro } \\
\text { digital }\end{array}$ & $\begin{array}{l}\text { Seções transversais } \\
\text { e distâncias até } 50 \\
\text { quilômetros }\end{array}$ & $\begin{array}{l}\text { Gravado em meio } \\
\text { magnético para uso em } \\
\text { plotter }\end{array}$ \\
\hline $\begin{array}{l}\text { Equipamento } \\
\text { multifeixe (towfish) e } \\
\text { posicionamento }\end{array}$ & $\begin{array}{l}\text { Geofísica } \\
\text { scan sonar })\end{array}$ & $\begin{array}{l}\text { Varredura vertical e } \\
\text { lateral }\end{array}$ & $\begin{array}{l}\text { Permite o levantamento } \\
\text { vertical e lateral do leito } \\
\text { e também das camadas } \\
\text { depositadas }\end{array}$ \\
\hline
\end{tabular}

Fonte: Carvalho et al. (2000b).

Os dados utilizados neste trabalho (descritos com mais detalhes na seção 4.2) foram obtidos a partir do uso de um receptor GPS com correções diferenciais (Differencial Global Positioning System - DGPS) e um ecobatímetro digital (sonda acústica). O DGPS foi utilizado para navegação e obtenção dos dados de localização, e o ecobatímetro digital foi empregado para obtenção dos pontos de cota do reservatório.

De acordo com Souza (2006), a utilização das sondas acústicas na batimetria deu-se a partir da Segunda Guerra Mundial, com a instalação de transdutores acústicos nos cascos 
dos navios para medição das superfícies de fundo de corpos hídricos. Ainda segundo o autor, a batimetria, a partir das sondas acústicas, teve grande avanço com a evolução da engenharia acústica e da informática, que proporcionou o aumento da precisão, da capacidade de coleta, armazenamento e processamento de dados.

Os levantamentos batimétricos se apresentam como uma importante ferramenta para melhorar o planejamento e o gerenciamento dos recursos hídricos, principalmente devido ao fato de, possibilitar a atualização dos dados operacionais de reservatórios que, em muitos casos, estão defasados devido aos problemas de depósitos de sedimentos.

A atualização dos dados operacionais dos reservatórios é importante, pois em muitos casos, as regras operacionais dos reservatórios são baseadas em curvas cota vs. área vs. volume desatualizadas, devido, por exemplo, a perdas de volume decorrente ao assoreamento ou dados obtidos em estimativas de projetos.

Em virtude desses fatos, em muitos reservatórios, as políticas de operação são realizadas a partir de dados incorretos e acarretam em erros na gestão e planejamento dos seus recursos hídricos.

A atualização dos dados operacionais dos reservatórios vem recebendo cada vez mais atenção, principalmente dos órgãos públicos e das concessionárias de energia. Este fato pode ser comprovado pela recente publicação da Resolução Conjunta n ${ }^{\circ}$ 3, de 10 de agosto de 2010 (BRASIL, 2010), elaborada pela ANA e Agência Nacional de Energia Elétrica (ANEEL) que estabelece as condições e procedimentos para instalação, operação e manutenção de estações hidrométricas que visam manter atualizados os dados pluviométricos, fluviométricos e sedimentométricos, entre outros, dos aproveitamentos hidrelétricos do país.

Segundo Carvalho (2008) e Santos et al. (2001), os levantamentos topobatimétricos de reservatórios permitem a: 
- Avaliação do volume de água atual do reservatório;

- Determinação da área do espelho de água, da geometria do leito do rio e das curvas cota vs. área vs. volume;

- Quantificação do sedimento assoreado durante um período;

- Investigação das características físicas dos sedimentos acumulados;

- Avaliação da descarga sólida afluente ao reservatório;

- Quantificação da capacidade de retenção de sedimentos do reservatório.

A medição da vazão dos cursos d'água e do volume hídrico, possibilitada pelos levantamentos batimétricos, é muito importante para diversas áreas de conhecimento, como: o balanço hídrico das bacias hidrográficas, os projetos e operações de obras hidráulicas, a previsão de enchentes, modelagem e simulação de aproveitamentos hidrelétricos, o gerenciamento ambiental, a navegação, a recreação e o abastecimento, entre outros.

A quantidade e frequência que os levantamentos batimétricos devem ser realizados são influenciadas por diversos fatores, como: o tamanho e o volume do reservatório, a carga sólida afluente ao curso d'água e os custos financeiros (CARVALHO et al., 2000b). Os mesmos autores apresentam uma classificação na Tabela 2, que relaciona o tamanho do reservatório com a frequência de levantamento desejáveis. Deve-se destacar que esta classificação não é rígida, ou seja, pode ser modificada ou adaptada para cada caso.

Tabela 2. Frequência aconselhada para levantamentos topobatimétricos em reservatórios.

\begin{tabular}{|c|c|c|}
\hline Porte do reservatório & Classificação em volume $\mathbf{( m}^{\mathbf{3}}$ ) & Frequência de levantamento \\
\hline Pequeno & $<10 \times 10^{6}$ & Cada 2 anos \\
\hline Médio & entre 10 a $100 \times 10^{6}$ & Cada 5 anos \\
\hline Grande & $>100 \times 10^{6}$ & Cada 10 anos \\
\hline
\end{tabular}

Fonte: Carvalho et al. (2000b). 
A partir da elaboração e comparação dos mapas batimétricos em diferentes épocas, é possível acompanhar, avaliar e quantificar periodicamente a evolução dos depósitos de sedimentos. Desse modo, com a comparação dos mapas batimétricos de diferentes épocas, pode-se determinar as perdas de volumes e identificar as áreas com maiores depósitos de sedimentos, o que possibilita adoção de medidas, preventivas e/ou corretivas, mais eficazes contra o assoreamento de corpos hídricos.

Diversos autores apresentam estudos baseados em levantamentos batimétricos, tanto na literatura acadêmica quanto técnica.

Corrêa Filho et al. (2005) citam em seu estudo no Reservatório de Ibitinga (SP), a importância da utilização dos levantamentos batimétricos para obtenção dos aspectos físicos e estimativas dos volumes de água dos reservatórios, além da determinação e acompanhamento dos depósitos de sedimentos. Neste estudo, os autores puderam obter, a partir da batimetria, as curvas e os polinômios cota $v s$. área $v s$. volume do reservatório estudado.

Paiva (1993) em seu estudo, realizado no Reservatório de Taquaruçu (MG), verificou a partir da comparação de dados de um levantamento batimétrico (realizado em 1992) com dados dos mapas originais do reservatório (1935), um acúmulo de $1.530 .000 \mathrm{~m}^{3}$ de sedimentos, o que provocou uma perda de $70 \%$ na capacidade útil do reservatório. O autor também destaca no seu estudo que as empresas deveriam controlar as vazões sólidas que chegam aos reservatórios e acompanhar, por meio dos levantamentos batimétricos, as variações de volume de sedimentos depositados em seus reservatórios.

Bufon (2006) analisou o tempo de vida útil da Represa Velha de Pirassununga (SP) através da comparação de levantamentos topobatimétricos (realizados entre 1998 e 2001) com dados iniciais da construção do reservatório (datados de 1940). A partir do estudo, o autor verificou uma significativa perda de profundidade em alguns trechos da represa e avaliou o tempo de vida útil da mesma em 50 anos. 
Miranda et al. (2010) apresentam em seu estudo a importância da atualização dos dados operacionais dos reservatórios hidrelétricos a partir de levantamentos batimétricos. Os autores destacam que muitos reservatórios operam, atualmente, com dados defasados e que este fato prejudica as políticas de planejamento e gerenciamento dos reservatórios. No estudo, os autores apresentam o caso do Reservatório de Três Irmãos que teve seus dados de cota $v s$. área vs. volume atualizados a partir de levantamentos batimétricos. 


\subsection{Modelos computacionais aplicados a análise de sistemas de recursos hídricos}

Em decorrência da má distribuição espaço-temporal dos recursos hídricos e do aumento da demanda hídrica, a alocação e o gerenciamento destes recursos tornam-se cada vez mais importantes, para evitar ou amenizar os conflitos entre os usuários e a escassez hídrica para determinadas regiões ou períodos.

Uma das melhores alternativas para resolver estes problemas é o emprego de metodologias matemáticas e computacionais. Segundo Yeh (1985), o desenvolvimento e a adoção de técnicas computacionais no planejamento e gerenciamento de sistemas hídricos foi um dos maiores avanços da área de engenharia de recursos hídricos.

O emprego de técnicas computacionais também é defendido por Azevedo et al. (1997), onde os autores citam que a crescente complexidade dos problemas de planejamento e gerenciamento dos recursos hídricos requer a utilização de técnicas e instrumentos capazes de auxiliar os profissionais envolvidos nestas áreas.

De acordo com Porto et al. (2003), a utilização de modelos matemáticos e computacionais é justificada, dentre outros fatos, devido a:

- Análise de um sistema real ser mais cara do que a utilização destes modelos;

- Os modelos são instrumentos eficientes para aprendizagem e treinamento, principalmente para simulações de emergências e situações de riscos;

- Conferir flexibilidade às análises, ou seja, possibilitar alteração de parâmetros, dados, regras operacionais ou até mesmo a configuração do sistema, fato este que permite a análise de diversas situações em um curto espaço de tempo; 
- Redução do tempo de análise, sobretudo quando o estudo está relacionado a fenômenos naturais que podem levar anos ou mesmo décadas.

Porto et al. (2003), afirmam que devido às peculiaridades dos problemas encontrados e da grande variabilidade dos métodos de solução, o campo de pesquisa para o uso de técnicas computacionais é muito grande. Os mesmos autores citam que a representação perfeita do sistema hídrico é uma tarefa muito difícil, pois existe um grande número de variáveis e incertezas que envolvem a descrição desses sistemas. Os autores destacam que o sucesso na modelagem dos sistemas analisados depende das considerações das leis que regem os processos físicos envolvidos e da descrição matemática precisa dessas leis. Ainda segundo os autores, os trabalhos de Yeh (1985), Simonovic ${ }^{18}$ (1992), Wurbs ${ }^{19}$ (1996) e Labadie $^{20}$ (1998) apresentam uma boa abordagem da aplicação das técnicas computacionais na solução de problemas práticos.

Atualmente, são encontrados na literatura diversos instrumentos e metodologias aplicadas à gestão e ao planejamento dos recursos hídricos, denominados como: Pesquisa Operacional, Análise de Sistemas de Recursos Hídricos, Sistemas de Suporte a Decisão, entre outros (ROBERTO e PORTO, 1999). Os autores citam que, apesar do grande desenvolvimento computacional ocorrido nos últimos anos, alguns problemas, como a alocação de água entre múltiplos usuários, não têm uma única solução genérica e totalmente satisfatória. Complementando a idéia apresentada, Yeh (1985) cita que a escolha do método que deve ser utilizado, por exemplo, para a análise do problema de alocação, depende das características do reservatório, das disponibilidades dos dados, dos objetivos e das restrições definidas, entre outros.

\footnotetext{
${ }^{18}$ SIMONOVIC, S. (1992). Reservoir systems analysis: closing gap between theory and practice. Journal Water Resources Planning and Management, New York. v. 118, n.3, p. 262-280.

${ }^{19}$ WURBS, R.A. (1996). Modeling and analysis of reservoir system operations. Prentice Hall.

${ }^{20}$ LABADIE, J.W. (1998). Decision support systems applied to water resources engineering. Curso promovido pela SABESP-EDUSP, São Paulo.
} 
Em virtude dos fatos apresentados, duas grandes classes de modelos vêm merecendo destaque na área de recursos hídricos: a simulação e a otimização. Dessa forma, será realizada a seguir, uma breve apresentação e discussão sobre os métodos de simulação e otimização, para facilitar a compreensão do modelo utilizado nesta pesquisa (Modelo de Rede de Fluxo) que apresenta características tanto de simulação quanto de otimização.

\subsubsection{Modelos de simulação em recursos hídricos}

Azevedo et al. (1997) definem a simulação, a partir de Maas et al. (1962), como sendo:

“[...] uma técnica de modelagem que é utilizada para aproximar o comportamento de um sistema no computador, representando todas as características do sistema por uma descrição matemática." (MAAS et al., 1962, apud AZEVEDO et al. 1997, p. 166).

Os modelos de simulação são muito utilizados no planejamento e na gestão dos recursos hídricos, principalmente em reservatórios hidrelétricos. De acordo com Yeh (1985), uma das primeiras utilizações dos modelos de simulação aplicada a reservatório, citada na literatura, foi o estudo realizado em 1953 pelo U.S. Amry Corps of Engineers para análise de operação de seis reservatórios do Rio Missouri (EUA).

Roberto e Porto (1999) justificam a grande utilização dos modelos de simulação em sistemas de recursos hídricos devido à facilidade para entendimento da sua utilização e dos resultados obtidos, tanto de profissionais da área quanto de não especialistas ou até mesmo leigos. Os autores citam ainda que, com o desenvolvimento da informática, as dificuldades e os tempos de cálculos estão sendo superados, tornando os modelos de simulação mais flexíveis, detalhados e representativos aos sistemas analisados. 
Assim, os modelos de simulação são capazes de representar com mais detalhes e realismo as características físicas, econômicas e sociais de um sistema de recurso hídrico (PORTO et al., 2003).

Além da flexibilidade citada anteriormente, Sadoun (2000) também ressalta a agilidade desses modelos no processo de simulação da operação de um sistema e a vantagem de poder utilizar séries sintéticas de vazões afluentes para simulação.

Cabe destacar, no entanto, que esses modelos também apresentam limitações. Uma das limitações mais citadas na literatura, acadêmica e técnica, deve-se ao fato dos modelos de simulação serem incapazes de encontrar os valores ótimos do sistema, ou seja, as variáveis de decisão que otimizem os critérios estabelecidos pelo usuário.

Porém, Porto et al. (2003) citam que apesar desta limitação (em gerar diretamente as soluções ótimas) os modelos de simulação podem apresentar uma solução pelo menos próxima da ótima, quando políticas alternativas são originadas por meio de numerosas simulações destes modelos.

A simulação computacional é uma técnica muito importante nos recursos hídricos, pois permite a análise, desde o projeto de obras até a manutenção e operação de um sistema hídrico.

Os fatos apresentados anteriormente ajudam a explicar o crescente avanço dos estudos e trabalhos, baseados nos modelos de simulação e relacionados com os recursos hídricos.

\subsubsection{Modelos de otimização em recursos hídricos}

Os modelos de otimização são utilizados para determinação da solução ótima de um sistema (PORTO et al., 2003), ou seja, estes modelos utilizam algoritmos computacionais 
para obtenção das melhores soluções possíveis para um sistema de acordo com os critérios estabelecidos pelo usuário, através da função objetivo e das restrições associadas ao problema.

Conforme Wurbs (1993) esclarece, a função objetivo e as restrições dos modelos de otimização são representadas por expressões matemáticas que dependem das variáveis de decisão do problema.

A função objetivo é uma expressão matemática que representa os anseios do decisor, como minimizar gastos ou maximizar benefícios. As restrições apresentam as limitações dos recursos disponíveis, restrições físicas ou estruturais de um sistema, entre outros. E as variáveis de decisão são os parâmetros representados na função objetivo e nas restrições que estão sob o controle do decisor e exercem influência na solução do problema de otimização (IGNIZIO, 1982).

De acordo com Wurbs (1993), as funções objetivos dos modelos de otimização são apresentadas, geralmente, em três grandes classes de objetivos: benefícios econômicos e custos; disponibilidade e confiabilidade hídricas e geração de energia elétrica. Ainda segundo o autor, estes modelos, na maioria das vezes, apresentam sua função objetivo com um único objetivo, convertendo os outros objetivos em restrições.

Labadie (1987 ${ }^{21}$ apud MAIA, 2006), cita que os modelos de otimização são muito importantes nos projetos da área de recursos hídricos para um maior aproveitamento dos recursos financeiros que são aplicados. Ainda segundo o autor:

“(1) os conceitos de sistemas operacionais integrados ótimos devem ser incorporados a nível de planejamento, para reduzir as dimensões de certos componentes, o que resultará em benefícios iguais a um menor custo, e (2) os sistemas existentes devem ser operados e administrados em todo o seu potencial." (LABADIE, 1987, apud MAIA, 2006, p. 36).

\footnotetext{
${ }^{21}$ LABADIE, J.W. (1987). Otimização da Operação de Projetos Hidroagrícolas. Tradução José Lins de A. filho. Fort Collins: Colorado State University, 249 p.
} 
Azevedo et al. (1997) destacam que uma das principais vantagens dos modelos de otimização em relação à simulação é quanto as alternativas analisadas. Segundo os autores, na otimização todas as alternativas são avaliadas implicitamente, enquanto a simulação restringe a análise a um número finito de alternativas.

Com relação às desvantagens apresentadas na literatura, entre os modelos de otimização e simulação, cabe destacar as simplificações que os modelos de otimização exigem. Azevedo et al. (1997), citam que os modelos de otimização geralmente demandam algumas simplificações na estrutura do modelo e nas restrições, diferente da simulação que é mais flexível. Os autores ainda citam que os modelos de otimização são, geralmente, mais difíceis de serem entendidos do que os modelos de simulação e que, muitas vezes, exigem a criação de programas computacionais para solução dos problemas apresentados.

Roberto e Porto (1999) também enfatizam que, devido às restrições computacionais, os modelos de otimização são forçados a simplificar o sistema em análise e este fato induz a uma desvantagem em relação à precisão, flexibilidade e representatividade dos modelos de simulação.

Por outro lado, com a evolução da tecnologia e da informática tem-se reduzido o nível de simplificações e aproximações que eram exigidos anteriormente para os modelos de otimização, possibilitando uma modelagem com maior realismo e precisão.

Nesse sentido, pode-se observar que tanto o modelo de simulação como os modelos de otimização, apresentam vantagens e desvantagens.

Dessa forma, diversos pesquisadores, defendem a utilização combinada dos modelos de simulação e otimização, como os modelos de rede de fluxo, visando restringir as limitações de ambos os modelos e utilizar suas principais vantagens de cada técnica. 


\subsubsection{Modelo de rede de fluxo}

Como apresentado anteriormente, existem vários modelos utilizados para a análise de sistemas de recursos hídricos. Um modelo muito utilizado na gestão e planejamento de recursos hídricos é a simulação através dos modelos de rede de fluxo (MRF). Conforme Porto et al. (2003) relatam, os modelos de rede de fluxo são uma classe de modelos de simulação que contêm um algoritmo de otimização.

Nos modelos de rede de fluxo, os sistemas de recursos hídricos são representados por uma rede formada por nós e arcos. Os nós representam os pontos de entrada e saída dos fluxos (como os reservatórios e as demandas) e os arcos representam os elos entre os nós (como os rios, canais, adutoras) onde ocorre o transporte de fluxos, conforme ilustrado na Figura 2. Os fluxos são as quantidades de um determinado produto que serão transportadas entre os nós (por unidade de tempo) e são as variáveis de decisão da rede de fluxo (PORTO et al., 2003).

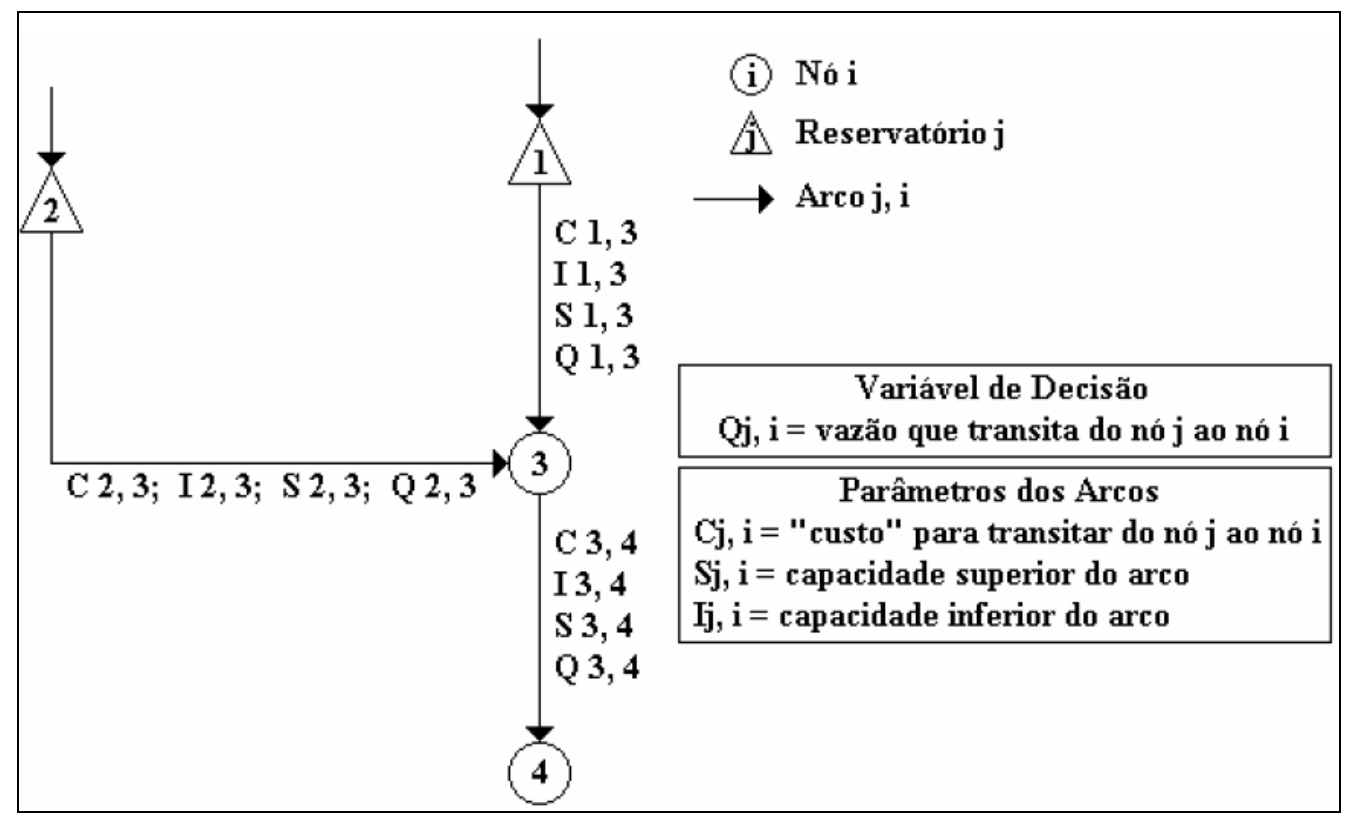

Figura 2. Representação de um sistema através de uma rede de fluxo.

Fonte: Azevedo et al. (1997). 
Sun et al. (1995) citam que dois itens são muito importantes para a caracterização de uma rede de fluxo: o balanço entre a oferta e a demanda e o ganho ou perda no transporte.

Segundo Azevedo et al. (1997), a utilização de modelos de rede de fluxo para análise de sistemas de recursos hídricos é interessante porque:

- Grande parte dos sistemas de recursos hídricos pode ser representada de forma adequada, real e bastante clara por meio de uma rede composta de nós e arcos;

- A flexibilidade, característica dos modelos de rede de fluxo, é capaz de representar bem o comportamento de um sistema de recursos hídricos;

- Estes modelos também incluem algoritmos de otimização que minimizam o custo total da rede, ou seja, definem os fluxos em todos os arcos de tal forma que a somatória dos custos da rede seja mínima.

Desse modo, os modelos de rede de fluxo agregam tanto características dos modelos de simulação (como a flexibilidade e adaptabilidade), quanto dos modelos de otimização (como a redução dos trabalhosos e demorados processos de tentativa e erro) (ROBERTO e PORTO, 1999). Outra vantagem destes modelos deve-se ao fato da modelagem do sistema hídrico levar em consideração as interações entre as águas superficiais e subterrâneas. Devido a estes atributos, os MRFs são bastante utilizados para análise de sistemas complexos e de grande escala (AZEVEDO et al., 1997).

Ainda segundo os autores, é importante destacar que, apesar dos modelos de rede serem muito vantajosos, eles também apresentam algumas limitações, como: permitir apenas a otimização de sistemas lineares (no entanto, já existem estudos para aplicação a sistemas não lineares) e admitir somente sistemas com dois tipos de restrição (manutenção do balanço de massa em cada nó; e limites, máximo e mínimo, para vazão em cada arco). Estes fatos 
exigem do usuário destes modelos um determinado grau de conhecimento e adoção de estratégias para representação adequada do sistema.

Diversos softwares baseados nos modelos de rede de fluxo são encontrados na literatura, entre os quais, pode-se citar: MODSIM desenvolvido na Colorado State University; AQUATOOL desenvolvido na Universidad Politécnica de Valencia; RIVERWARE desenvolvido na University of Colorado's Center Advanced Decision Support for Water and Environmental Systems juntamente com a Tennesse Valley Authority e o U.S. Bureau of Reclamation; CALSIM desenvolvido pela California State Departament of Water Resourses; CRAM - Central Resource Allocation Model do Hydrosphere, Inc. e o HECPRM do Hydrologic Eng. Center (ALBANO, 2004; BARROS, 2010).

O software utilizado neste trabalho é o AcquaNet uma modificação do MODSIM. A escolha deste software deve-se, entre outros motivos, ao fato do MODSIM ser um dos MRFs mais utilizados na área acadêmica, além do fato de ser um software livre e versátil, com teste em uma variedade de situações e estudos, conforme relatam AZEVEDO et al. (1997).

Os autores ainda enfatizam a capacidade do software em gerar planos operacionais para satisfazer metas, prioridades ou limitações de um sistema, e do programa computacional poder ser utilizado como instrumento para o planejamento ou gerenciamento de recursos hídricos.

Mais detalhes sobre o funcionamento do software AcquaNet, bem como a apresentação das suas características, seus dados de entrada e resultados de saída, entre outros, serão apresentados a seguir na seção 4.3. 


\section{MATERIAIS E MÉTODOS}

\subsection{Caracterização da área de estudo}

O Reservatório da Usina Hidrelétrica de Três Irmãos está localizado na Bacia Hidrográfica do Baixo Tietê (Figura 3), a noroeste do Estado de São Paulo, e corresponde à Unidade de Gerenciamento de Recursos Hídricos nº 19 (UGRHI-19).

As informações descritas nesta seção foram obtidas a partir do Plano de Bacia do Baixo Tietê 2008 - Relatório Final (CETEC, 2008).

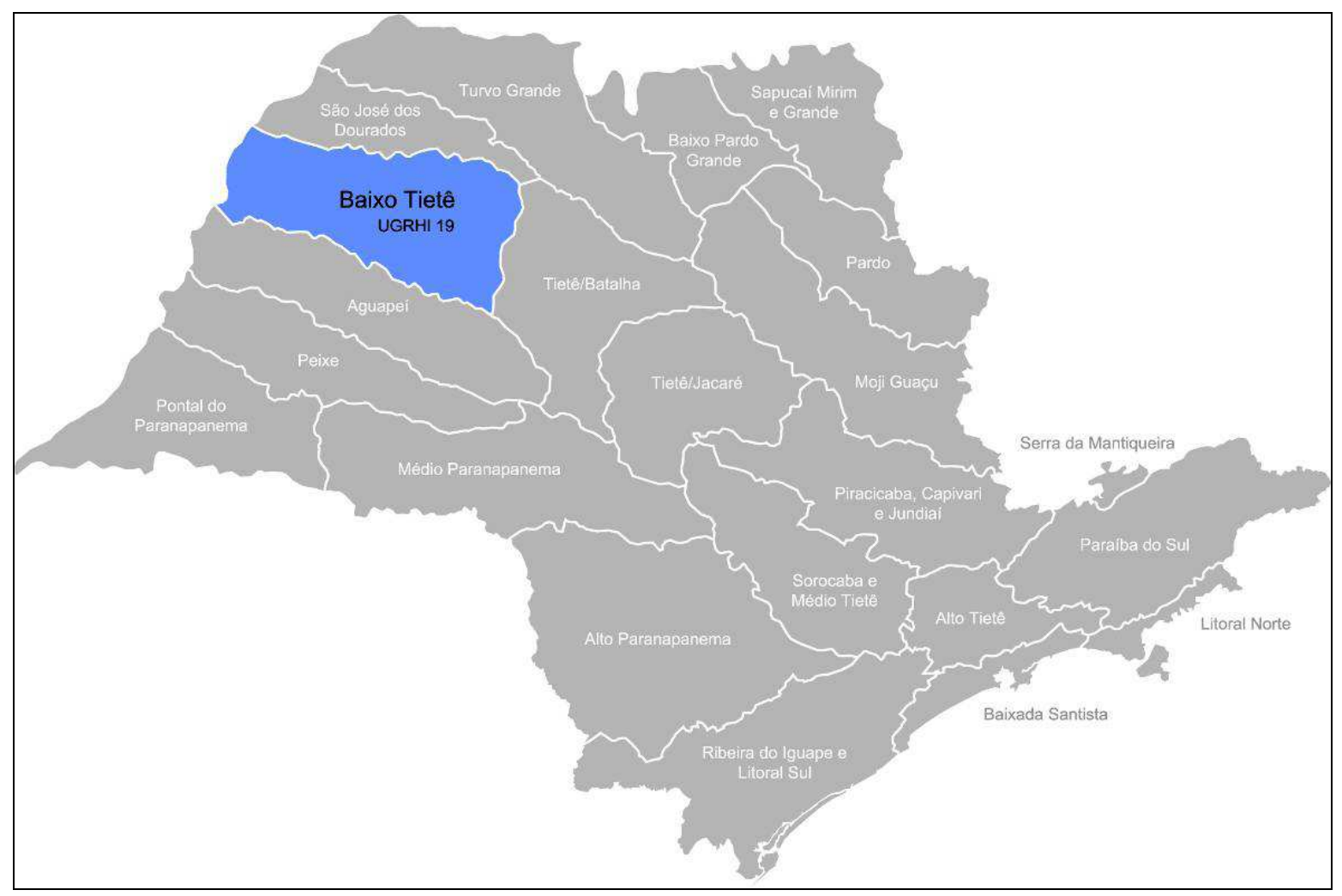

Figura 3. Unidades de Gerenciamento de Recursos Hídricos do Estado de São Paulo, com destaque para a UGRHI ${ }^{\circ} 19$ - Baixo Tietê.

Fonte: CETEC (2008).

A UGRHI do Baixo Tietê possui uma área de drenagem de $15.471 \mathrm{~km}^{2}$ com perímetro aproximado de $580 \mathrm{~km}$, onde estão contidos os reservatórios de Três Irmãos e Nova 
Avanhandava (Rio Tietê) e o Reservatório de Jupiá (Rio Paraná), que integram a Hidrovia Tietê-Paraná. Os principais cursos d'água desta UGRHI são os rios Tietê e Paraná e seus afluentes.

A área de abrangência da Bacia do Baixo Tietê é de $18.621 \mathrm{~km}^{2}$, área esta que corresponde a aproximadamente $7,49 \%$ da área do Estado de São Paulo $\left(248.600 \mathrm{~km}^{2}\right)$. A região da UGRHI-19 apresentava em 2007 cerca de 726.001 habitantes (SEADE, 2007), equivalente a $1,79 \%$ da população do Estado de São Paulo (Figura 4), em quarenta e dois municípios, dentre os quais destacam-se: Araçatuba, Birigui, Andradina, Pereira Barreto e Penápolis.
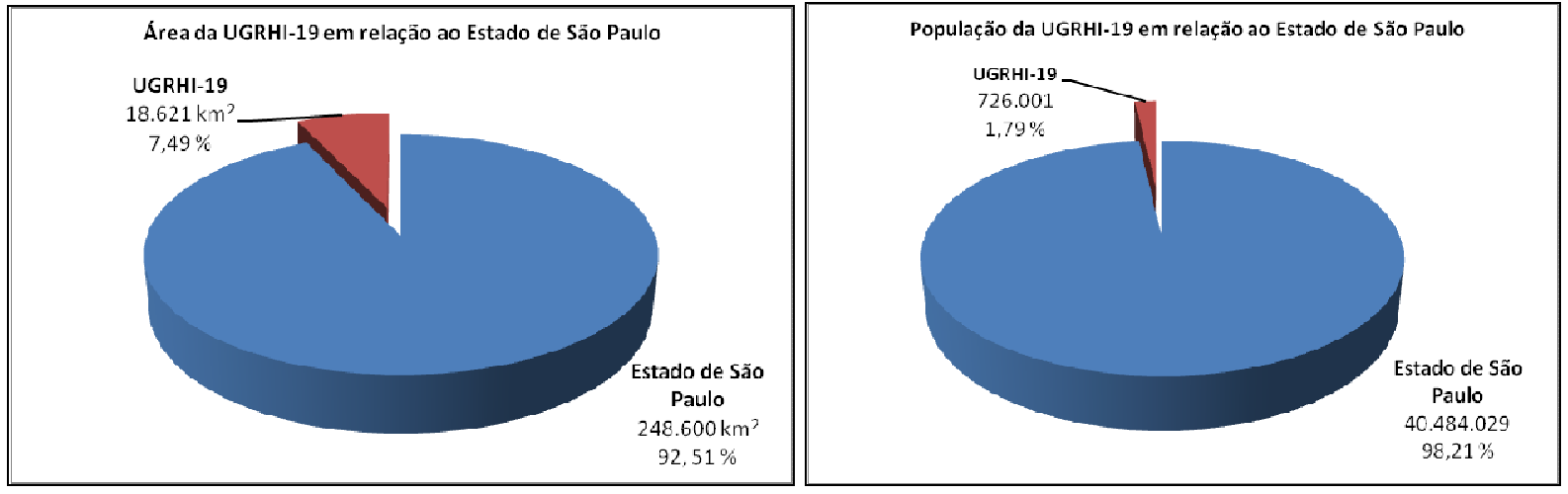

Figura 4. Área e população da Bacia do Baixo Tietê comparada ao Estado de São Paulo. Fonte: Adaptada de CETEC (2008).

A ocupação da região desta UGRHI teve início no auge da expansão cafeeira (final do século XIX) motivado pela busca de terras férteis para o plantio de café. Com a "crise do café” e exaustão das terras para plantio, a cafeicultura atravessou as fronteiras do Paraná e surgiram novas atividades na região, como a sericultura, cotonicultura e a pecuária, que ainda é uma das principais atividades econômicas da região.

A partir da década de 70, com a implantação do Programa Nacional do Álcool (Proálcool), a pecuária começou a perder espaço para o plantio de cana-de-açúcar que foi impulsionada pela implantação de várias usinas de açúcar e álcool na região. Atualmente, a 
economia da UGHRI-19 é baseada em atividades agropecuárias e em indústrias dos setores frigoríficos, calçadista e sucro-alcooleiro, esta última merece especial destaque pelo grande avanço nestes últimos anos.

Por estes motivos, a Secretaria Estadual de Meio Ambiente classifica a Bacia do Baixo Tietê como sendo uma Unidade de Gerenciamento de Recursos Hídricos Agropecuária (Figura 5).

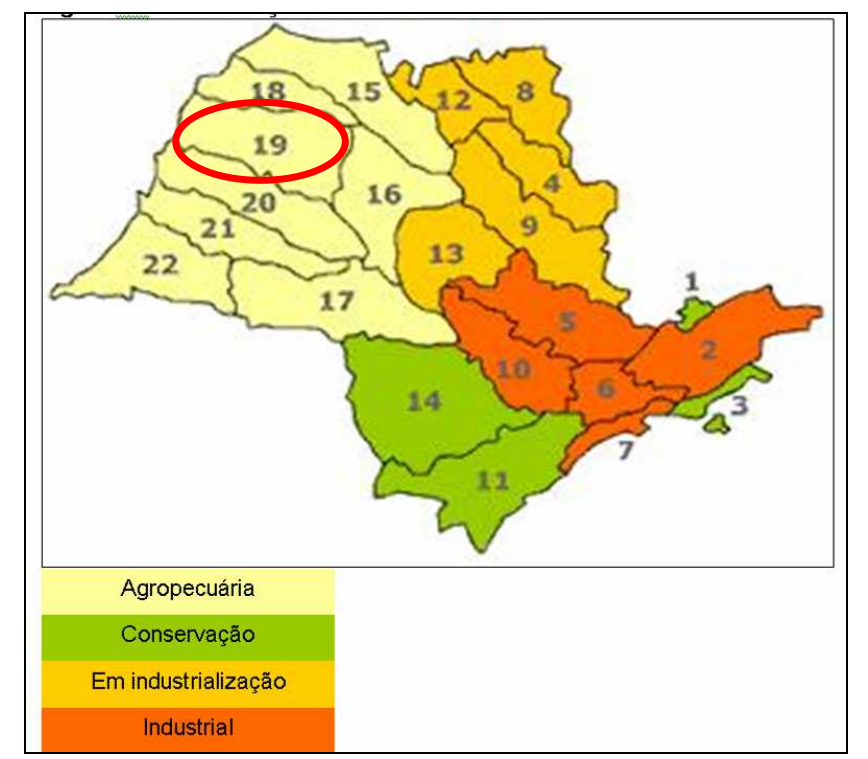

Figura 5. Classificação das UGRHIs segundo a Secretaria do Meio Ambiente, com destaque a UGRHI-19. Fonte: CETEC (2008).

As mudanças no uso e ocupação do solo da região da UGRHI-19, conforme apresentado anteriormente, ocasionam impacto direto nos recursos hídricos, como o aumento da demanda de água, principalmente para as atividades agropecuárias.

As principais classes de consumo hídrico da Bacia do Baixo Tietê são apresentados na Tabela 3 e foram estimados a partir de cadastros existentes nos órgãos oficiais do Estado de São Paulo como o Departamento de Águas e Energia Elétrica (DAEE), a Companhia Ambiental do Estado de São Paulo (CETESB), a Coordenadoria de Assistência Técnica Integral (CATI), entre outros. 
Os dados apresentados a seguir também foram complementados por uma empresa especializada contratada pelo Comitê do Baixo Tietê para cadastramento dos irrigantes, pelo fato deste uso não ser atualizado pelos órgãos oficiais com a frequência desejada. No entanto, cabe destacar que a Tabela 3, conforme pode ser observado, ainda não dispõe do cadastro completo dos usuários de irrigação.

Tabela 3. Resumo das demandas consuntivas da UGHRI Baixo Tietê.

\begin{tabular}{|c|c|c|}
\hline Uso & Vazão $\left(\mathbf{m}^{\mathbf{3}} / \mathbf{s}\right)$ & Porcentagem da vazão por uso (\%) \\
\hline Urbano & 1,52 & 15,69 \\
\hline Industrial & 4,70 & 48,50 \\
\hline Agricultura & 3,11 & 32,09 \\
\hline Aquicultura & 0,36 & 3,72 \\
\hline TOTAL & $\mathbf{9 , 6 9}$ & $\mathbf{1 0 0 , 0 0}$ \\
\hline
\end{tabular}

Fonte: CETEC (2008).

Entre os usos e as atividades desenvolvidas na bacia em questão, cabe destacar, além da geração de energia elétrica, a aquicultura, a recreação e a navegação. Todo o trecho do Rio Tietê compreendido pela UGRHI-19 é navegável, através das eclusas de Promissão, Nova Avanhandava e Três Irmãos, além do Canal de Pereira Barreto que interliga os reservatórios de Ilha Solteira e Três Irmãos e possibilita o transporte de produtos agrícolas e minerais, entre outros.

Os solos predominantes na região desta bacia hidrográfica são: Podzólicos, Latossolo Vermelho Escuro e Latossolo Roxo. Com relação à erosão, cerca de $70 \%$ da área total da bacia correspondem a áreas com alto grau de potencialidade à erosão, 25\% a áreas com médio grau e 5\% a áreas com baixo grau.

A Bacia do Baixo Tietê apresenta um acelerado processo de degradação devido aos processos erosivos. O Comitê da Bacia Hidrográfica do Baixo Tietê (CBH-BT) propôs três níveis de classificação de degradação e os resultados mostraram que das 33 sub-bacias que 
constituem o Baixo Tietê, 20 estão classificadas como "Muito degradadas" (66,6\%), 10 são "Degradadas" (30,3\%) e apenas 3 são consideradas "Pouco Degradadas".

Os diferentes usos do solo da região da UGRHI-19 são apresentados na Tabela 4 e Figura 6, e são baseados em estimativas do Levantamento Censitário das Unidades de Produção Agropecuária - LUPA (ano base 2005) realizado pela Coordenadoria de Assistência Técnica Integral $^{22}$, com complementações do Instituto de Economia Agrícola (IEA) ${ }^{23}$.

Tabela 4. Distribuição (hectare e percentual) dos diferentes usos do solo na UGRHI-19.

\begin{tabular}{|c|c|c|}
\hline \multirow{2}{*}{ Diferentes usos } & \multicolumn{2}{|c|}{ Área } \\
\cline { 2 - 3 } & Hectare & $\mathbf{( \% )}$ \\
\hline Pastagens & $1.115 .130,9$ & 59,5 \\
\hline Cultura temporária & $407.944,3$ & 21,8 \\
\hline Área de água & $103.400,0$ & 5,5 \\
\hline Vegetação natural & $78.411,3$ & 4,2 \\
\hline Outros usos & $72.018,0$ & 3,9 \\
\hline Cultura perene & $38.523,0$ & 2,1 \\
\hline Área complementar & $34.359,4$ & 1,8 \\
\hline Área em descanso & $13.414,0$ & 0,7 \\
\hline Reflorestamentos & $5.959,3$ & 0,3 \\
\hline Área de brejos e/ou várzeas & $2.939,5$ & 0,2 \\
\hline Total (*) & $\mathbf{1 . 8 7 1 . 7 0 0}$ & $\mathbf{1 0 0 , 0}$ \\
\hline
\end{tabular}

Fonte: CETEC (2008). (*) Área física sem considerar os limites da UGRHI.

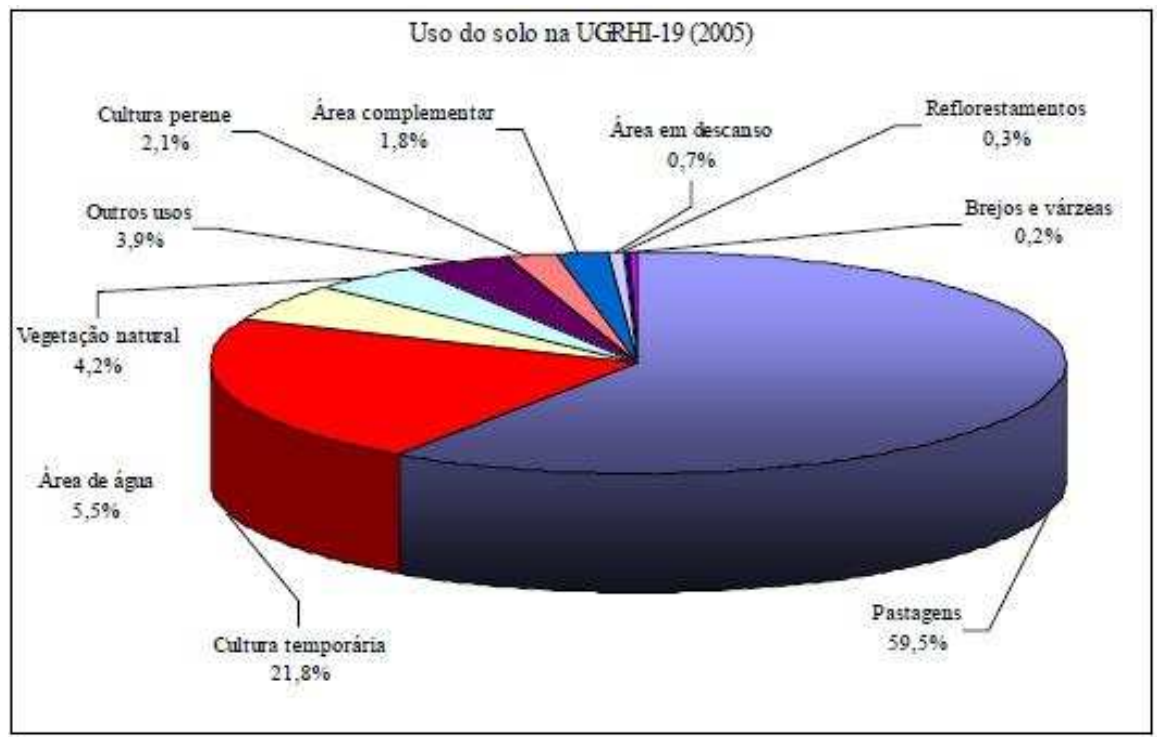

Figura 6. Distribuição dos diferentes usos do solo na UGRHI-19.

Fonte: CETEC (2008).

\footnotetext{
${ }^{22}$ Coordenadoria de Assistência Técnica Integral - CATI. Disponível em: http://www.cati.sp.gov.br.

${ }^{23}$ Instituto de Economia Agrícola - IEA. Disponível em: http://www.iea.sp.gov.br.
} 
Como é possível observar a partir da Tabela 4 e da Figura 6, o principal uso do solo desta UGRHI $(59,5 \%)$ deve-se às atividades pecuárias. Cabe ressaltar também o uso das culturas temporárias (pequenos ciclos), com 21,8\%, onde merece destaque a cultura de canade-açúcar. A área de água (5,5\%) faz referência aos reservatórios das UHEs de Três Irmãos e Nova Avanhandava. As culturas perenes representam culturas com longo ciclo de exploração como as seringueiras para extração do látex.

Outras áreas que merecem destaque, apesar de representarem uma pequena parcela do uso do solo da UGRHI (0,2\%), são as áreas de brejos e/ou várzeas, pois estas formações encontram-se próximas às matas ciliares dos corpos hídricos. As áreas descritas como complementares são áreas reservadas às construções e benfeitorias nas propriedades rurais (casas, açudes, estradas, entre outros). E as áreas denominadas de outros usos são destinadas ás áreas urbanas e rodovias.

Quanto ao clima, devido à localização, a Bacia do Baixo Tietê sofre grande influência das massas de ar Tropical Continental e Polar Antártica, que influenciam diretamente na temperatura da região. No inverno, com a intensificação da Massa de Ar Polar, ocorre queda das temperaturas e julho que geralmente é o mês mais frio, apresenta temperaturas médias entre $14^{\circ} \mathrm{C}$ e $22^{\circ} \mathrm{C}$. Já o verão que sofre influência da Massa de $\mathrm{Ar}$ Tropical Atlântica é um período quente e úmido com temperaturas médias entre $24^{\circ} \mathrm{C}$ e $30^{\circ} \mathrm{C}$. O regime pluviométrico da região é o tropical típico, com variações anuais entre $1.000 \mathrm{~mm}$ e $1.300 \mathrm{~mm}$ e períodos chuvosos de dezembro a abril, e períodos de estiagem de maio a novembro. 


\subsubsection{Reservatório de Três Irmãos}

O Reservatório da UHE de Três Irmãos (Figura 7) está localizado entre os municípios de Andradina e Pereira Barreto, a 28 km da confluência do Rio Tietê com o Rio Paraná e possui aproximadamente $150 \mathrm{~km}$ de extensão, sendo o sexto barramento do Rio Tietê. O reservatório possui uma área de $785 \mathrm{~km}^{2}$ e sua barragem tem comprimento de 3640 metros. O reservatório da usina é de acumulação e serve para regularização de vazão e contenção de cheias (CESP, 2010).

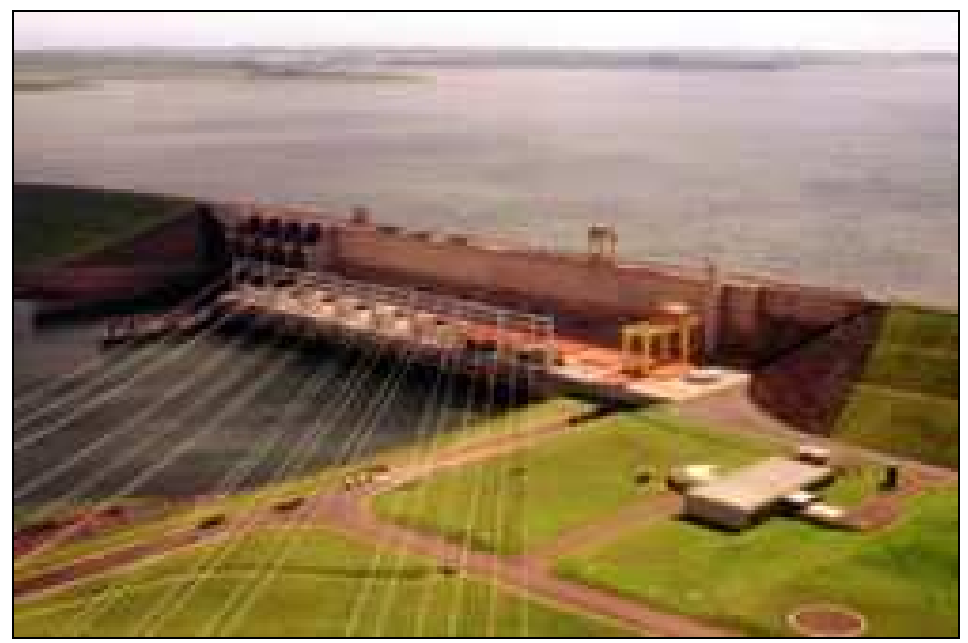

Figura 7. Imagem da UHE de Três Irmãos.

Fonte: CESP (2010).

O Reservatório de Três Irmãos apresenta uma característica muito interessante e peculiar que é a interligação com o Rio São José dos Dourados, afluente da margem esquerda do Rio Paraná e do Reservatório de Ilha Solteira, através do canal artificial denominado “Canal de Pereira Barreto" (Figura 8). O canal, considerado o segundo maior do mundo, tem cerca de $9.600 \mathrm{~m}$ de comprimento e propicia a operação energética integrada dos dois aproveitamentos hidrelétricos (UHE de Três Irmãos e UHE de Ilha Solteira), além de permitir a navegação entre o norte e o sul da Hidrovia Tietê-Paraná. 
A transposição hídrica das bacias hidrográficas dos rios Tietê e Paraná, possibilitada pelo canal, é realizada de forma livre, ou seja, não existe estrutura para o controle do nível de água dos reservatórios. O sentido do escoamento no canal é devido à afluência de água nos reservatórios, ou seja, dos seus níveis d'água.

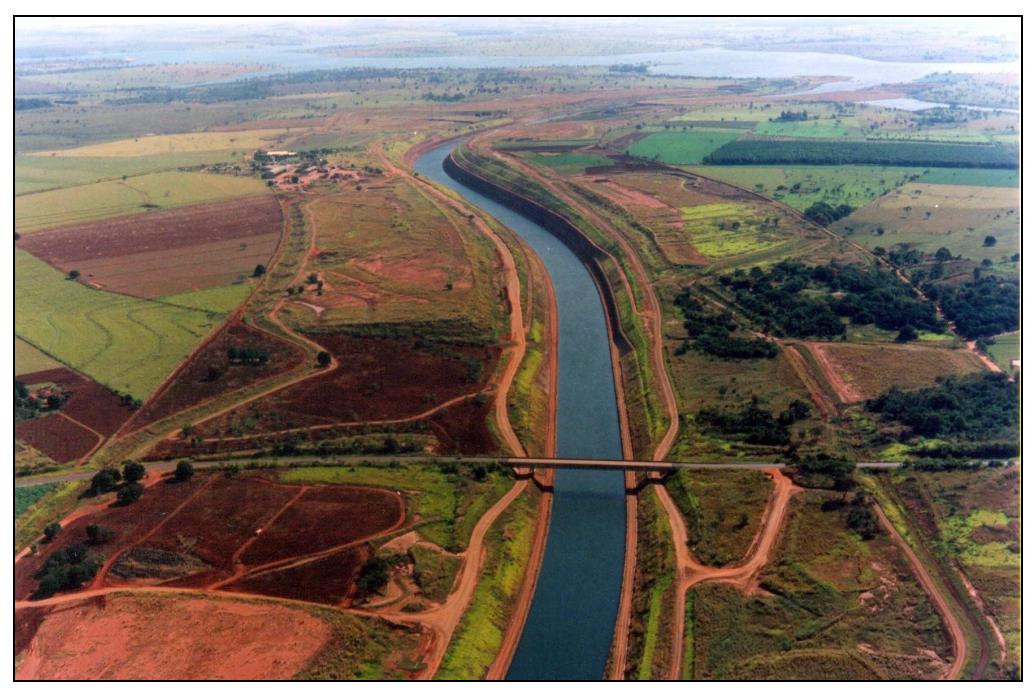

Figura 8. Imagem do Canal de Pereira Barreto.

Fonte: UNESP (2010).

A Usina de Três Irmãos é a maior usina do Rio Tietê e tem capacidade de operar com oito turbinas, totalizando uma potência instalada de 1292 MW, porém, atualmente, possui cinco turbinas do tipo Francis com potência instalada total de 807,50 MW. A primeira unidade entrou em operação em novembro de 1993 e a quinta em janeiro de 1999 (CESP, 2010).

Além da UHE de Três Irmãos, há outros aproveitamentos hidrelétricos localizados na UGRHI do Baixo Tietê/Paraná como demonstrado na Figura 9. 


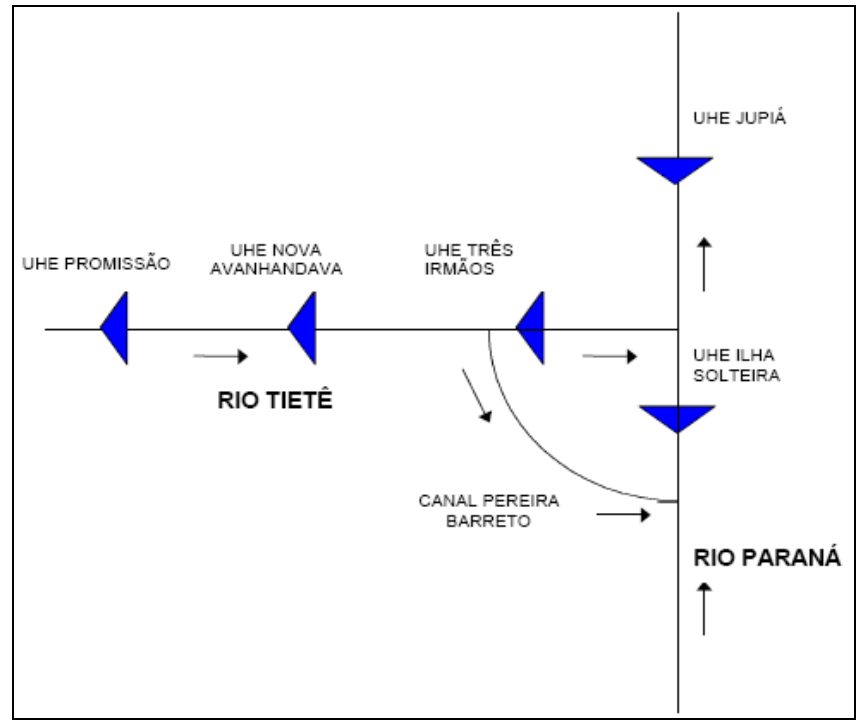

Figura 9. Esquema unifilar dos aproveitamentos hidrelétricos do Baixo Tietê/Paraná.

Fonte: CETEC (1999).

As principais características do Reservatório e da UHE de Três Irmãos estão descritas na Tabela 5.

Tabela 5. Principais características do Reservatório e da UHE de Três Irmãos.

\begin{tabular}{|l|r|}
\hline Concessionária & CESP \\
\hline Município & Pereira Barreto \\
\hline Manancial & Tietê \\
\hline \multicolumn{2}{|c|}{ Condições de montante } \\
\hline Área da bacia hidrográfica & $69.900 \mathrm{~km}^{2}$ \\
\hline Área do espelho d'água (N.A. ${ }^{24} 328,40 \mathrm{~m}$ ) & $785 \mathrm{~km}^{2}$ \\
\hline Volume total & $13.371 \times 10^{6} \mathrm{~m}^{3}$ \\
\hline Volume morto & $10.000 \times 10^{6} \mathrm{~m}^{3}$ \\
\hline Volume útil & $3.450 \times 10^{6} \mathrm{~m}^{3}$ \\
\hline Volume reservado para cheia de projeto & $350 \times 10^{6} \mathrm{~m}^{3}$ \\
\hline \multicolumn{2}{|c|}{ Barragem de concreto e de terra } \\
\hline Tipo Níveis característicos de montante \\
\hline Comprimento no coroamento \\
\hline \multicolumn{2}{|c|}{ Gravidade } \\
\hline N.A. máximo maximorum ${ }^{25}$ & $3.640 \mathrm{~m}$ \\
\hline N.A. máximo útil & $328,40 \mathrm{~m}$ \\
\hline N.A. mínimo útil & $328,00 \mathrm{~m}$ \\
\hline Vazão média a longo termo - MLT (período 1931 - 2005) & $323,00 \mathrm{~m}$ \\
\hline
\end{tabular}

\footnotetext{
${ }^{24}$ N.A.: Nível d'água.

${ }^{25}$ N.A. máximo maximorum: "Nível mais elevado da superfície de água para o qual a estrutura foi projetada. É geralmente fixado como o nível correspondente a superelevação máxima, quando da ocorrência da cheia de projeto." Fonte: http://www.duke-energy.com.br/negocios/dicionario.asp?G_ID=496\&Letra=N\&id=.
} 


\begin{tabular}{|l|r|}
\hline \multicolumn{2}{|c|}{ Condições de jusante } \\
\hline N.A. máximo maximorum & $284,75 \mathrm{~m}$ \\
\hline N.A. máximo & $282,40 \mathrm{~m}$ \\
\hline N.A. mínimo & $279,00 \mathrm{~m}$ \\
\hline Vazão máxima dos descarregadores (N.A. 328,00 m) & $8.996 \mathrm{~m}^{3} / \mathrm{s}$ \\
\hline Vazão turbinada nominal total (5 máquinas) & $2.040 \mathrm{~m}^{3} / \mathrm{s}$ \\
\hline \multicolumn{2}{|c|}{ Unidades geradoras - Turbinas } \\
\hline Tipo \\
\hline Turbinas \\
\hline Potência nominal unitária & $165.000 \mathrm{~kW}$ \\
\hline Queda de referência & $42,00 \mathrm{~m}$ \\
\hline Engolimento máximo & $449 \mathrm{~m}^{3} / \mathrm{s}$ \\
\hline \multicolumn{2}{|c|}{ Unidades geradoras - Geradores } \\
\hline Tipo & ABB/Siemens/Alsthom \\
\hline Potência nominal & $161.500 \mathrm{~kW}$ \\
\hline Potência nominal total instalada & $807.500 \mathrm{~kW}$ \\
\hline
\end{tabular}

Fonte: CESP (2010). 


\subsection{Dados de entrada do Reservatório de Três Irmãos}

Os dados de entrada utilizados na realização desta pesquisa foram obtidos a partir de diversas fontes de informações como: o Operador Nacional do Sistema Elétrico (ONS), a Agência Nacional de Águas, a Agência Nacional de Energia Elétrica, entre outros.

A Companhia Energética de São Paulo (CESP), concessionária de energia que atualmente administra a Usina de Três Irmãos, também foi uma importante fonte para obtenção de dados operacionais da usina.

A vazão afluente ao Reservatório de Três Irmãos, utilizada para simulação do reservatório, foi obtida a partir do ONS e seus dados correspondem ao período de 1931 a 2008, conforme apresentado na Tabela 6.

Tabela 6. Vazão afluente ao Reservatório de Três Irmãos.

\begin{tabular}{|c|c|c|c|c|c|c|c|c|c|c|c|c|}
\hline ANO & JAN & FEV & MAR & ABR & MAI & JUN & JUL & AGO & SET & OUT & NOV & DEZ \\
\hline 1931 & 1812 & 3417 & 2273 & 1605 & 1050 & 772 & 611 & 499 & 707 & 640 & 652 & 1584 \\
\hline 1932 & 1627 & 1446 & 1471 & 905 & 785 & 758 & 519 & 502 & 385 & 543 & 496 & 1421 \\
\hline 1933 & 1238 & 1022 & 746 & 503 & 540 & 430 & 371 & 313 & 343 & 381 & 293 & 499 \\
\hline 1934 & 843 & 878 & 689 & 476 & 342 & 303 & 252 & 232 & 284 & 351 & 278 & 1667 \\
\hline 1935 & 866 & 1582 & 1321 & 795 & 485 & 482 & 362 & 375 & 594 & 1431 & 663 & 645 \\
\hline 1936 & 1161 & 853 & 1411 & 737 & 514 & 353 & 316 & 366 & 651 & 424 & 422 & 1289 \\
\hline 1937 & 1899 & 1280 & 1215 & 1288 & 957 & 828 & 495 & 427 & 349 & 660 & 924 & 1009 \\
\hline 1938 & 1040 & 842 & 879 & 723 & 574 & 480 & 381 & 424 & 472 & 744 & 675 & 1034 \\
\hline 1939 & 1580 & 1248 & 863 & 694 & 614 & 554 & 400 & 317 & 304 & 275 & 487 & 898 \\
\hline 1940 & 1676 & 2655 & 1421 & 775 & 623 & 448 & 355 & 305 & 292 & 349 & 520 & 575 \\
\hline 1941 & 857 & 529 & 535 & 478 & 277 & 251 & 294 & 226 & 457 & 689 & 754 & 957 \\
\hline 1942 & 889 & 1149 & 1191 & 833 & 528 & 489 & 571 & 338 & 321 & 288 & 324 & 726 \\
\hline 1943 & 854 & 1067 & 1048 & 602 & 371 & 353 & 288 & 263 & 306 & 523 & 648 & 433 \\
\hline 1944 & 691 & 678 & 1227 & 556 & 355 & 277 & 260 & 210 & 199 & 189 & 370 & 336 \\
\hline 1945 & 360 & 1062 & 737 & 457 & 307 & 462 & 632 & 278 & 244 & 232 & 482 & 554 \\
\hline 1946 & 1131 & 1437 & 1487 & 794 & 511 & 500 & 479 & 331 & 258 & 381 & 388 & 355 \\
\hline 1947 & 1173 & 1618 & 2167 & 862 & 679 & 530 & 525 & 471 & 561 & 660 & 449 & 1074 \\
\hline 1948 & 1346 & 1659 & 1559 & 1030 & 683 & 555 & 448 & 486 & 350 & 362 & 552 & 509 \\
\hline 1949 & 736 & 1074 & 847 & 779 & 543 & 430 & 370 & 293 & 272 & 260 & 327 & 979 \\
\hline 1950 & 1277 & 2207 & 1862 & 1221 & 849 & 635 & 541 & 400 & 331 & 660 & 569 & 865 \\
\hline 1951 & 1415 & 1920 & 1845 & 1076 & 722 & 625 & 542 & 471 & 390 & 404 & 478 & 781 \\
\hline 1952 & 836 & 1123 & 1445 & 806 & 464 & 552 & 394 & 308 & 327 & 369 & 526 & 397 \\
\hline 1953 & 762 & 742 & 477 & 578 & 344 & 336 & 270 & 270 & 301 & 339 & 360 & 504 \\
\hline 1954 & 705 & 1049 & 860 & 474 & 708 & 571 & 357 & 272 & 226 & 278 & 287 & 331 \\
\hline 1955 & 836 & 403 & 598 & 417 & 268 & 290 & 276 & 245 & 320 & 213 & 412 & 471 \\
\hline 1956 & 574 & 448 & 661 & 401 & 603 & 907 & 484 & 729 & 434 & 417 & 359 & 349 \\
\hline 1957 & 1047 & 1263 & 941 & 917 & 504 & 407 & 617 & 487 & 842 & 612 & 763 & 804 \\
\hline 1958 & 781 & 1496 & 1451 & 1059 & 999 & 1182 & 729 & 520 & 590 & 540 & 802 & 910 \\
\hline
\end{tabular}




\begin{tabular}{|c|c|c|c|c|c|c|c|c|c|c|c|c|}
\hline NO & $\mathbf{A N}$ & FEV & MAR & $\overline{\mathrm{ABR}}$ & MAI & JUN & JUL & AGO & SET & OUT & NOV & $\overline{\mathrm{DEZ}}$ \\
\hline 1959 & 423 & 1215 & 1042 & 939 & 582 & 463 & 415 & 424 & 356 & 363 & 383 & 737 \\
\hline 960 & 390 & 09 & & 836 & 672 & 4 & - & & & 201 & 627 & 1171 \\
\hline 1961 & 086 & 99 & 1598 & 1007 & 887 & 566 & 450 & 401 & 377 & 365 & 487 & 547 \\
\hline 1962 & 771 & 30 & 1840 & 872 & 566 & 528 & 404 & 384 & 406 & 656 & 619 & 727 \\
\hline 963 & 072 & 445 & 065 & 65 & 387 & 371 & 373 & 343 & 4 & 0 & 78 & 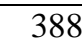 \\
\hline 964 & 255 & 91 & 4 & 324 & 361 & 270 & 285 & 308 & 883 & 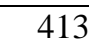 & 441 & 778 \\
\hline 965 & 312 & 55 & 2270 & 1054 & 1101 & 740 & 99 & 436 & 339 & 77 & 94 & 1565 \\
\hline 966 & 394 & 285 & 1417 & 739 & 554 & 399 & 335 & 342 & 389 & 510 & 653 & 1178 \\
\hline 967 & 594 & 787 & 1402 & 796 & 505 & 637 & 465 & 309 & 430 & 529 & 761 & 949 \\
\hline 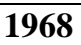 & 97 & & & 606 & 480 & 447 & 368 & 372 & 321 & 363 & 271 & 427 \\
\hline & & & & 40 & & 268 & 202 & 189 & 165 & 366 & 746 & 560 \\
\hline 7 & 06 & 1813 & & 93 & 608 & 468 & 416 & 335 & 71 & 489 & 413 & 501 \\
\hline 1 & 715 & & & 25 & 4 & 576 & 499 & 371 & 343 & 548 & 364 & 560 \\
\hline 197 & 104 & 040 & 126 & 815 & 576 & 480 & 628 & 542 & 530 & 1419 & 975 & 778 \\
\hline 197 & 959 & & & 859 & 6 & 490 & 489 & 11 & 475 & 557 & 664 & 953 \\
\hline & 1669 & & & 1238 & 62 & 661 & 570 & 00 & 376 & 453 & 486 & 1001 \\
\hline & & & & & & 438 & 469 & & 19 & 549 & 604 & 234 \\
\hline & & & & 31 & & 479 & 257 & 1100 & 228 & 1386 & 1095 & 233 \\
\hline 77 & 40 & & & 11 & & 757 & 567 & & 29 & 5 & 707 & 790 \\
\hline 1 & 84 & & 10 & 510 & 6 & 64. & 636 & 59 & 497 & 397 & 872 & 1000 \\
\hline 1 & 68 & & & 566 & & 407 & 470 & & 735 & 561 & 697 & 1093 \\
\hline ( & 78 & 1 & & 975 & & 575 & 568 & & 463 & 457 & 503 & 1014 \\
\hline & & & & & & & & & & 590 & 26 & 1045 \\
\hline & 14 & & & & & , & 974 & & 07 & & & 2093 \\
\hline 1 & 20 & & & 770 & $0 y$ & 3761 & 466 & 1030 & 1596 & 10 & 41 & 1564 \\
\hline 198 & & & & & & & 52 & & & & 543 & 814 \\
\hline & 17 & & & & & 590 & 518 & & & 364 & 459 & 509 \\
\hline 1 & 565 & & & 655 & & 424 & 401 & & & 370 & 435 & 1304 \\
\hline & & & & & & & & & & & 40 & 834 \\
\hline & & & & 48 & & $\overline{O C C}$ & & & & & 31 & 754 \\
\hline & J & & & & & & & 10 & & & $T$ & 904 \\
\hline 199 & 2389 & & & & & & & & & & 02 & 794 \\
\hline & & 2124 & & 75 & & & & & & & 553 & 910 \\
\hline & & & & & & & & & & 41 & 984 & 1101 \\
\hline & 5 & & & & & & & & & & 554 & 680 \\
\hline & & & & & & & & & & & 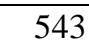 & 920 \\
\hline & & & & 1474 & & & & & & & 75 & 761 \\
\hline 1 & 15 & & & 1 & & & & & & 776 & 753 & 911 \\
\hline 199 & 1908 & & & & & 1188 & 131 & & & 71 & 1033 & 1115 \\
\hline 1998 & 947 & & & & & & Jou & & & 50 & 606 & 1277 \\
\hline 1999 & 2673 & & & & & & & & & U & $\overline{550}$ & 746 \\
\hline & & & & & & & & & & & $\overline{02}$ & 1071 \\
\hline & & & & & & & & & & & 597 & 1003 \\
\hline & 1670 & & & & & & & & & 28.0 & 585 & 858 \\
\hline & 1365 & & & & & & 4 & & 2 & 393 & 576 & 802 \\
\hline & 877 & & & 809 & & $80 \mathrm{~J}$ & 713 & 463 & 372 & 520 & 111 & 806 \\
\hline 2005 & 1636 & & & 49 & & & 1 & 29 & 467 & 553 & 571 & 864 \\
\hline 20 & 975 & & & 1046 & & & & & & 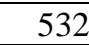 & 394 & 1018 \\
\hline & 84 & & & 60 & & & & & & & 140 & 774 \\
\hline 200 & 1013 & 1. & 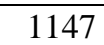 & 962 & 82 & 72 & 46 & 561 & 37 & 528 & 477 & 566 \\
\hline
\end{tabular}

Fonte: ONS (2010).

As taxas de evaporação do Reservatório de Três Irmãos também foram obtidas a partir do ONS e seguem apresentadas na Tabela 7. 
Tabela 7. Taxas de evaporação líquida do Reservatório de Três Irmãos (mm).

\begin{tabular}{|c|c|c|c|c|c|c|c|c|c|c|c|c|}
\hline Local & Jan. & Fev. & Mar. & Abr. & Maio & Jun. & Jul. & Ago. & Set. & Out. & Nov. & Dez. \\
\hline Três Irmãos & 22 & 17 & 27 & 42 & 55 & 54 & 46 & 43 & 47 & 18 & 1 & 14 \\
\hline
\end{tabular}

Fonte: ONS (2004).

Como citado anteriormente, para a análise da questão do assoreamento no reservatório em questão, foram utilizados os dados disponibilizados pela CESP (1975) e os dados obtidos a partir de levantamentos batimétricos (2008) referentes à cota vs. área vs. volume do reservatório.

É importante destacar que as informações obtidas pela batimetria do reservatório, são dados primários, ou seja, obtidos pelo próprio Núcleo de Hidrometria do Centro de Recursos Hídricos e Ecologia Aplicada (CRHEA) do Departamento de Hidráulica e Saneamento (SHS) da Escola de Engenharia de São Carlos (EESC). Este fato merece destaque, principalmente devido: à carência de dados atuais sobre as condições dos reservatórios brasileiros, à dificuldade para o acesso aos dados operacionais das usinas e dos reservatórios, à grande dimensão do reservatório e ao tempo e trabalho empregado para obtenção destes dados.

\subsubsection{Dados do reservatório - CESP (1975)}

Os dados fornecidos pela CESP referente ao reservatório foram obtidos a partir do Projeto Básico de Três Irmãos elaborado pela PROMON-THEMAG entre os anos de 1975 e 1976 (CESP, 2010).

Esses dados são importantes, pois apesar de antigos, ainda são utilizados pela CESP para o gerenciamento e operação do Reservatório e da Usina de Três Irmãos.

A utilização desses dados e a comparação com os dados atuais do reservatório tiveram como intenção comprovar a importância da atualização dos dados operacionais dos reservatórios e demonstrar a influência que o processo de assoreamento provoca na geração 
de energia elétrica, uma vez que acarreta a diminuição do volume útil do reservatório e consequente redução da vazão regularizada.

Assim, com os dados fornecidos pela CESP foi possível analisar quais foram as mudanças que ocorreram durante esta época (1975) até o presente momento, com a comparação com os dados obtidos através dos levantamentos batimétricos.

A Tabela 8 apresenta uma parte dos dados fornecidos pela CESP referente à cota $v s$. área $v s$. volume do reservatório.

Tabela 8. Parte dos dados de cota vs. área vs. volume do reservatório fornecidos pela CESP.

\begin{tabular}{|c|c|c|}
\hline Cota $\mathbf{( m )}$ & Área $\left.\mathbf{( 1 0}^{\mathbf{6}} \mathbf{~ m}^{\mathbf{2}}\right)$ & Volume $\mathbf{( 1 0}^{\mathbf{6}} \mathbf{~ m}^{\mathbf{3}} \mathbf{)}$ \\
\hline 280,000 & 0,00 & 0,00 \\
\hline 285,000 & 5,90 & 18,25 \\
\hline 290,000 & 38,60 & 129,50 \\
\hline 295,000 & 114,50 & 512,25 \\
\hline 300,000 & 179,90 & 1248,25 \\
\hline 305,000 & 260,30 & 2348,75 \\
\hline 310,000 & 340,40 & 3850,50 \\
\hline 315,000 & 429,90 & 5776,25 \\
\hline 320,000 & 535,40 & 8189,50 \\
\hline 323,000 & 620,42 & 9923,23 \\
\hline 324,000 & 648,76 & 10557,82 \\
\hline 325,000 & 677,10 & 11220,75 \\
\hline 326,000 & 703,58 & 11911,09 \\
\hline 327,000 & 730,06 & 12627,91 \\
\hline 328,000 & 756,54 & 13371,21 \\
\hline 329,000 & 783,02 & 14140,99 \\
\hline 330,000 & 809,50 & 14937,25 \\
\hline
\end{tabular}

Fonte: CESP (2010).

\subsubsection{Dados do reservatório - Levantamentos batimétricos (2008)}

Como citado anteriormente, os dados para caracterização do reservatório no cenário atual foram obtidos a partir de levantamentos batimétricos realizados durante o ano de 2008.

As informações descritas a seguir e os procedimentos adotados para suas coletas foram obtidos através do Projeto de Pesquisa e Desenvolvimento "Estudos do assoreamento 
do reservatório formado pela barragem da UHE Três Irmãos" (FIPAI, 2009) realizado pela equipe do Núcleo de Hidrometria (CRHEA/SHS/EESC/USP) em parceria com a CESP e a Fundação para o Incremento da Pesquisa e do Aperfeiçoamento Industrial (FIPAI). Os equipamentos e softwares utilizados para realização deste trabalho são de propriedade do próprio Núcleo de Hidrometria.

Para obtenção dos dados referentes ao reservatório, foram efetuadas quatro campanhas batimétricas realizadas pelos técnicos do Núcleo de Hidrometria José Roberto Maramarque e Waldomiro Antônio Filho, no período de fevereiro a setembro de 2008.

$\mathrm{Na}$ batimetria do reservatório foram levantados 500 transectos (seções), com a captação de 48.283 pontos, que apresentavam dados de localização (latitude e longitude) e cota de nível de água, obtidos em 40 dias de coleta de campo.

Os transectos foram planejados em uma configuração contínua, em "zigue-zague", perpendiculares ao eixo longitudinal do curso d'água e espaçados entre si, em aproximadamente 1,5 km, conforme ilustrado na Figura 10.

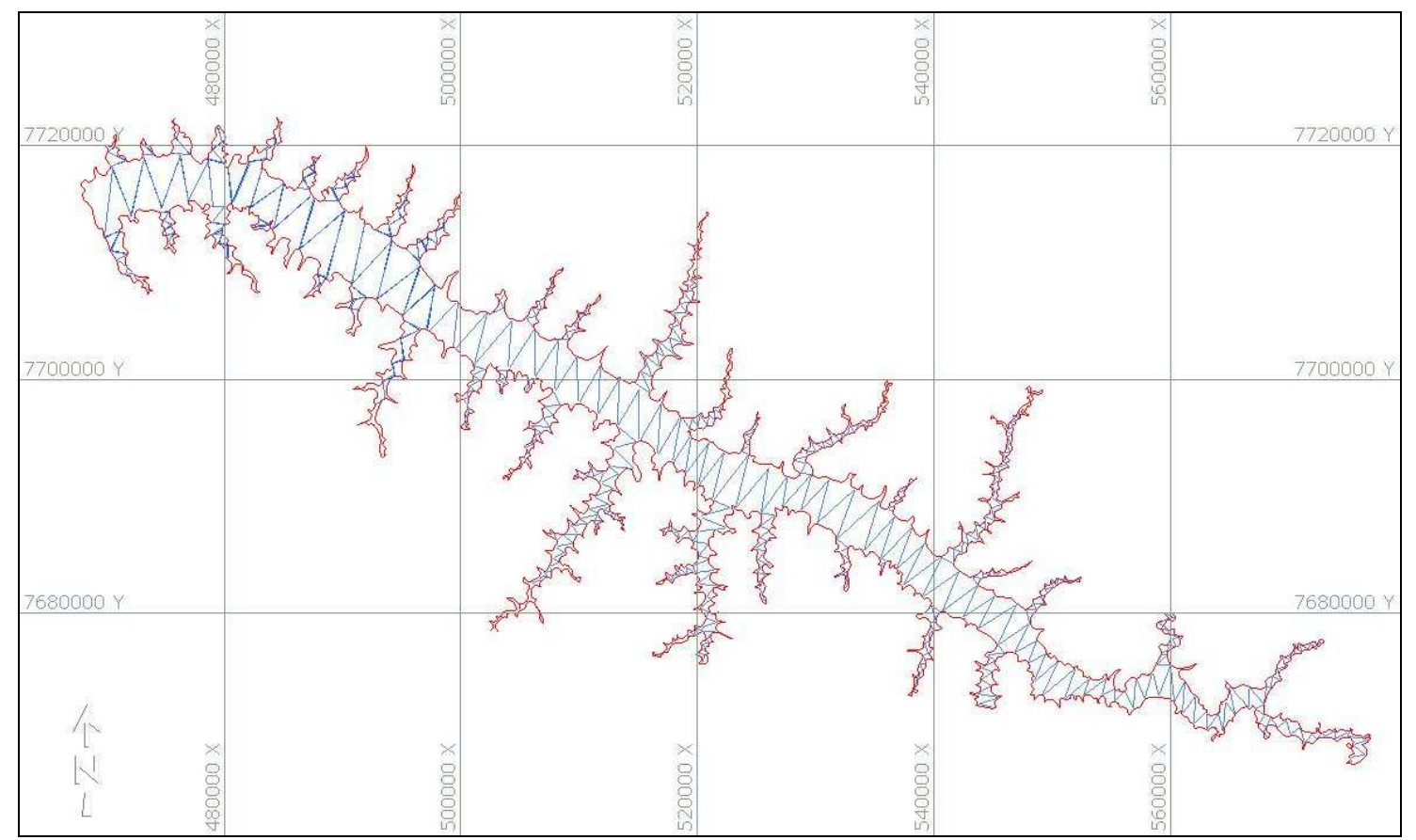

Figura 10. Seções batimétricas no Reservatório de Três Irmãos.

Fonte: FIPAI (2009). 
Para coleta dos dados do reservatório foram utilizados o ecobatímetro (sonda acústica) modelo Echo Sounder Bathy 500MF da SyQwest Inc. e o receptor GPS Leica Geosystems GS20 com correções diferenciais - DGPS (Differencial Global Positioning System), ambos conectados a um computador (Figura 11).

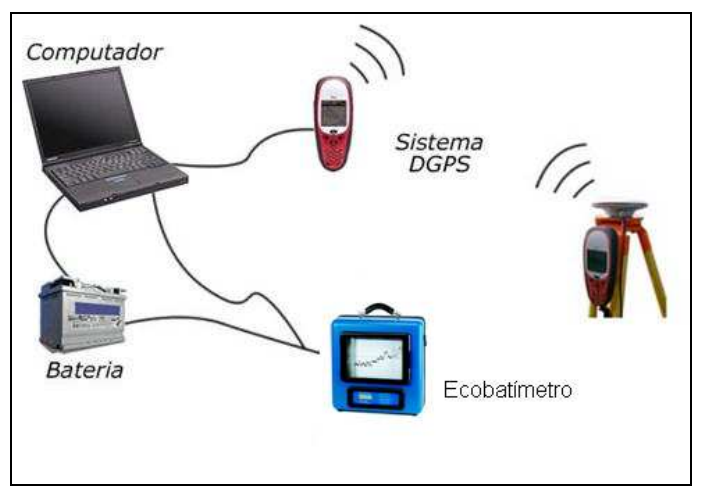

Figura 11. Equipamentos utilizados na batimetria do Reservatório de Três Irmãos.

Fonte: FIPAI (2009).

Como citado na seção 3.4, o princípio de funcionamento do ecobatímetro é baseado na emissão de ondas sonoras para medição e representação de relevos de áreas submersas a partir da estimativa do tempo em que as ondas emitidas pelo aparelho sejam refletidas e retornem ao mesmo. Assim, pode-se calcular a trajetória que o sinal percorreu, ou seja, os valores de profundidade (Figura 12). E o GPS foi utilizado para navegação e obtenção dos dados de localização.

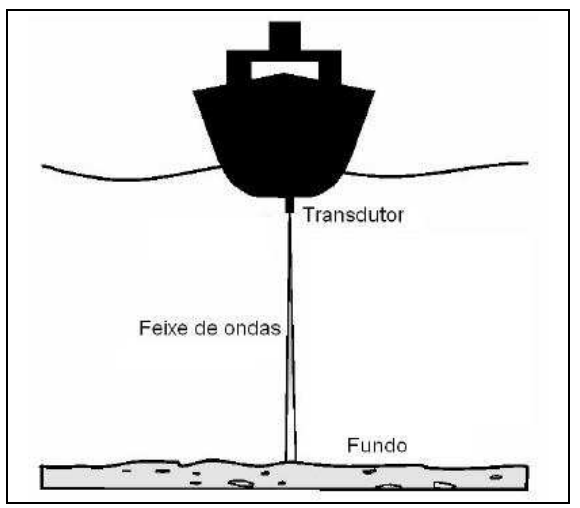

Figura 12. Ilustração de um barco utilizando o ecobatímetro para medição da área submersa. 
O software utilizado para aquisição e processamento dos dados e para planejamento das seções batimétricas realizadas foi o Hypack®.

Após a coleta dos dados, realizou-se a seleção, tratamento e processamento dos dados, visando descartar informações desnecessárias e pontos discrepantes dos valores esperados, que geralmente são originados por diversos motivos. Uma das principais causas de origem destes pontos é a presença de materiais como galhos ou troncos no fundo do reservatório.

A partir do tratamento e processamento dos dados foi possível gerar o Modelo Digital do Terreno (MDT) do reservatório, com a utilização do software TopoGRAPH 98SE® e através da modelagem de superfície por meio do método de triangulação de Delaunay ${ }^{26}$. O MDT consiste em uma matriz de números que representam a distribuição geográfica de elevação (MENDES e CIRILO, 2001) e permite representar a superfície do reservatório.

Desse modo, com a utilização do TopoGRAPH 98SE® pôde-se calcular a área referente a cada curva de nível do reservatório em intervalos de 1 em 1 metro a partir da cota mínima. Os dados calculados (Tabela 9) foram inseridos em uma planilha eletrônica (Excel®) onde foram gerados a curva e o polinômio cota $v s$. área que melhor representava os dados (Figura 13).

Tabela 9. Parte dos dados de cota vs. área do reservatório obtidos a partir dos levantamentos batimétricos.

\begin{tabular}{|c|c|c|c|}
\hline Cota $(\mathbf{m})$ & Área $\left(\mathbf{m}^{\mathbf{2}}\right)$ & Cota $(\mathbf{m})$ & Área $\left(\mathbf{m}^{\mathbf{2}}\right)$ \\
\hline 285 & $4.123 .508,9282$ & 308 & $267.166 .691,6832$ \\
\hline 286 & $7.182 .053,2140$ & 309 & $279.751 .590,4172$ \\
\hline 287 & $11.683 .305,7450$ & 310 & $293.230 .626,0093$ \\
\hline 288 & $17.636 .147,8763$ & 311 & $307.818 .845,0662$ \\
\hline 289 & $24.471 .341,8639$ & 312 & $322.395 .081,4827$ \\
\hline 290 & $30.035 .438,7677$ & 313 & $338.352 .952,3222$ \\
\hline
\end{tabular}

\footnotetext{
${ }^{26}$ Método utilizado para construção de uma malha de triângulos interligados, de forma a se obter uma aproximação que represente a superfície de um terreno a partir de dados reais. Fonte: http://www.uefs.br/disciplinas/exa519/DICIONARIO_14.pdf.
} 


\begin{tabular}{|c|c|c|c|}
\hline Cota $(\mathbf{m})$ & Área $\left.\mathbf{( m}^{\mathbf{2}}\right)$ & Cota $(\mathbf{m})$ & Área $\left(\mathbf{m}^{\mathbf{2}}\right)$ \\
\hline 291 & $45.229 .368,8790$ & 314 & $354.537 .941,8283$ \\
\hline 292 & $61.033 .153,5518$ & 315 & $371.344 .667,4750$ \\
\hline 293 & $73.760 .478,2234$ & 316 & $388.085 .117,8309$ \\
\hline 294 & $88.661 .437,4276$ & 317 & $405.568 .035,5247$ \\
\hline 295 & $103.562 .396,6317$ & 318 & $424.824 .017,0249$ \\
\hline 296 & $115.355 .887,0294$ & 319 & $444.693 .873,6936$ \\
\hline 297 & $122.727 .390,8065$ & 320 & $465.392 .980,4222$ \\
\hline 298 & $130.149 .380,9118$ & 321 & $486.484 .625,3968$ \\
\hline 299 & $137.872 .025,2685$ & 322 & $507.618 .063,8262$ \\
\hline 300 & $146.392 .094,8397$ & 323 & $530.623 .878,3514$ \\
\hline 301 & $155.243 .334,5208$ & 324 & $554.454 .490,0363$ \\
\hline 302 & $175.956 .639,7331$ & 325 & $577.698 .451,5681$ \\
\hline 303 & $191.865 .851,5802$ & 326 & $600.809 .533,8996$ \\
\hline 304 & $214.483 .488,4204$ & 327 & $624.451 .578,5514$ \\
\hline 305 & $229.859 .640,4633$ & 328 & $648.694 .899,5107$ \\
\hline 306 & $242.409 .022,8365$ & 329 & $673.566 .197,9559$ \\
\hline 307 & $254.580 .368,3709$ & 330 & $699.067 .591,3015$ \\
\hline
\end{tabular}

Fonte: FIPAI (2009).

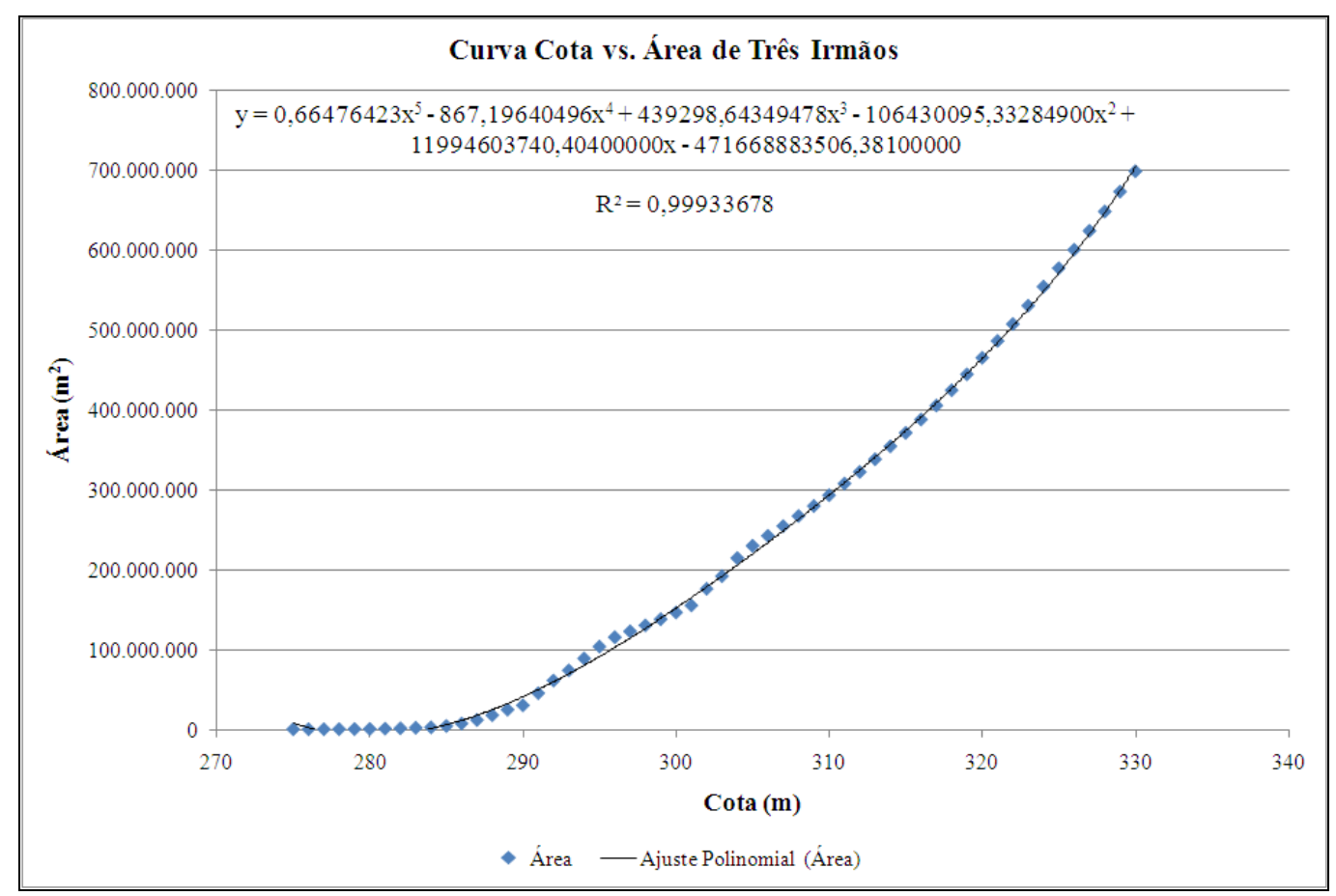

Figura 13. Curva e polinômio cota vs. área do reservatório obtidos a partir da batimetria.

Fonte: FIPAI (2009).

O volume do reservatório foi calculado a partir dos dados da Tabela 9 e também foram gerados em intervalos de 1 em 1 metro a partir da cota mínima. Para o cálculo foi 
considerado o particionamento do reservatório seguindo as suas curvas de nível, conforme ilustrado na Figura 14.

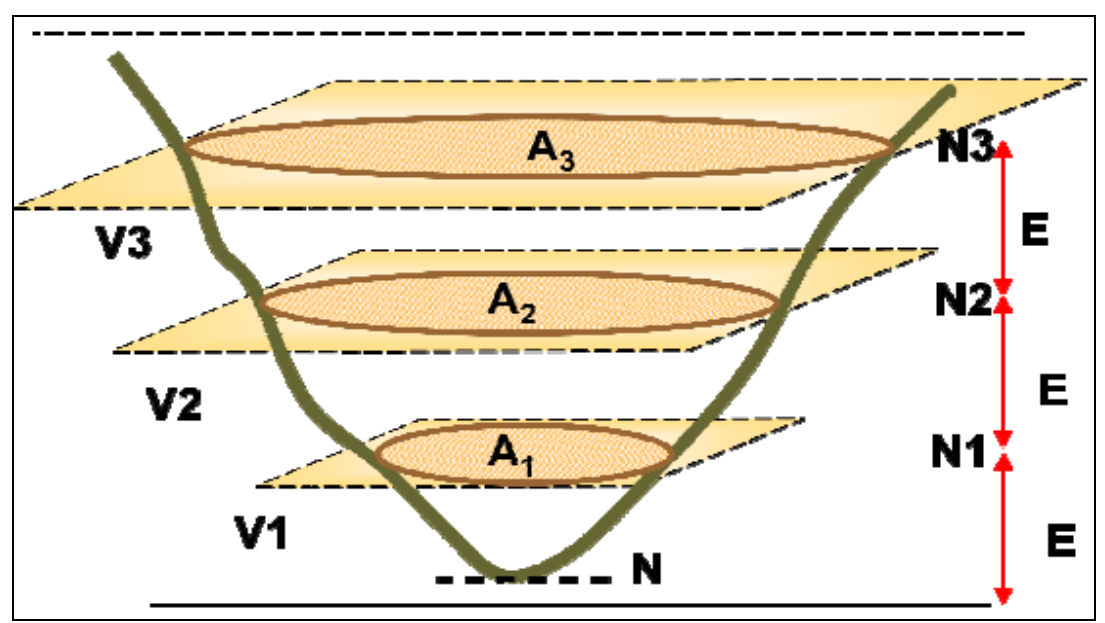

Figura 14. Ilustração do método empregado para o cálculo do volume do reservatório - particionamento pelas curvas de nível.

Fonte: FIPAI (2009).

A partir dos planos formados pelas curvas de nível, calculou-se o volume de cada secção do reservatório. Assim, com a soma de cada volume de secção foi possível determinar o volume total do reservatório.

Os dados obtidos, relativos ao volume de cada cota (Tabela 10), foram inseridos em uma planilha eletrônica (Excel®) para geração da curva e do polinômio que melhor relacionava os dados, conforme apresentado na Figura 15.

Tabela 10. Parte dos dados de cota vs. volume do reservatório obtidos a partir dos levantamentos batimétricos.

\begin{tabular}{|c|r|c|c|}
\hline Cota $(\mathbf{m})$ & \multicolumn{1}{|c|}{ Volume $\left.\mathbf{( m}^{\mathbf{3}}\right)$} & Cota $(\mathbf{m})$ & Volume $\left.\mathbf{( m}^{\mathbf{3}}\right)$ \\
\hline 285 & $9.729 .205,0974$ & 308 & $2.725 .524 .552,3646$ \\
\hline 286 & $15.381 .986,1685$ & 309 & $2.998 .983 .693,4148$ \\
\hline 287 & $24.814 .665,6480$ & 310 & $3.285 .474 .801,6280$ \\
\hline 288 & $39.474 .392,4587$ & 311 & $3.585 .999 .537,1658$ \\
\hline 289 & $60.528 .137,3288$ & 312 & $3.901 .106 .500,4402$ \\
\hline 290 & $87.781 .527,6446$ & 313 & $4.231 .480 .517,3427$ \\
\hline 291 & $125.413 .931,4679$ & 314 & $4.577 .925 .964,4179$ \\
\hline
\end{tabular}




\begin{tabular}{|c|c|c|c|}
\hline Cota $(\mathbf{m})$ & Volume $\left.\mathbf{( m}^{\mathbf{3}}\right)$ & Cota $(\mathbf{m})$ & Volume $\left.\mathbf{( m}^{\mathbf{3}}\right)$ \\
\hline 292 & $178.545 .192,6833$ & 315 & $4.940 .867 .269,0696$ \\
\hline 293 & $245.942 .008,5709$ & 316 & $5.320 .582 .161,7225$ \\
\hline 294 & $327.152 .966,3964$ & 317 & $5.717 .408 .738,4003$ \\
\hline 295 & $423.264 .883,4260$ & 318 & $6.132 .604 .764,6751$ \\
\hline 296 & $532.724 .025,2566$ & 319 & $6.567 .363 .710,0344$ \\
\hline 297 & $651.765 .664,1745$ & 320 & $7.022 .407 .137,0923$ \\
\hline 298 & $778.204 .050,0337$ & 321 & $7.498 .345 .940,0018$ \\
\hline 299 & $912.214 .753,1238$ & 322 & $7.995 .397 .284,6133$ \\
\hline 300 & $1.054 .346 .813,1779$ & 323 & $8.514 .518 .255,7021$ \\
\hline 301 & $1.205 .164 .527,8582$ & 324 & $9.057 .057 .439,8959$ \\
\hline 302 & $1.370 .764 .514,9851$ & 325 & $9.623 .133 .910,6981$ \\
\hline 303 & $1.554 .675 .760,6418$ & 326 & $10.212 .387 .903,4320$ \\
\hline 304 & $1.757 .850 .430,6421$ & 327 & $10.825 .018 .459,6575$ \\
\hline 305 & $1.980 .021 .995,0839$ & 328 & $11.461 .591 .698,6885$ \\
\hline 306 & $2.216 .156 .326,7338$ & 329 & $12.122 .722 .247,4218$ \\
\hline 307 & $2.464 .651 .022,3375$ & 330 & $12.809 .039 .142,0505$ \\
\hline
\end{tabular}

Fonte: FIPAI (2009).

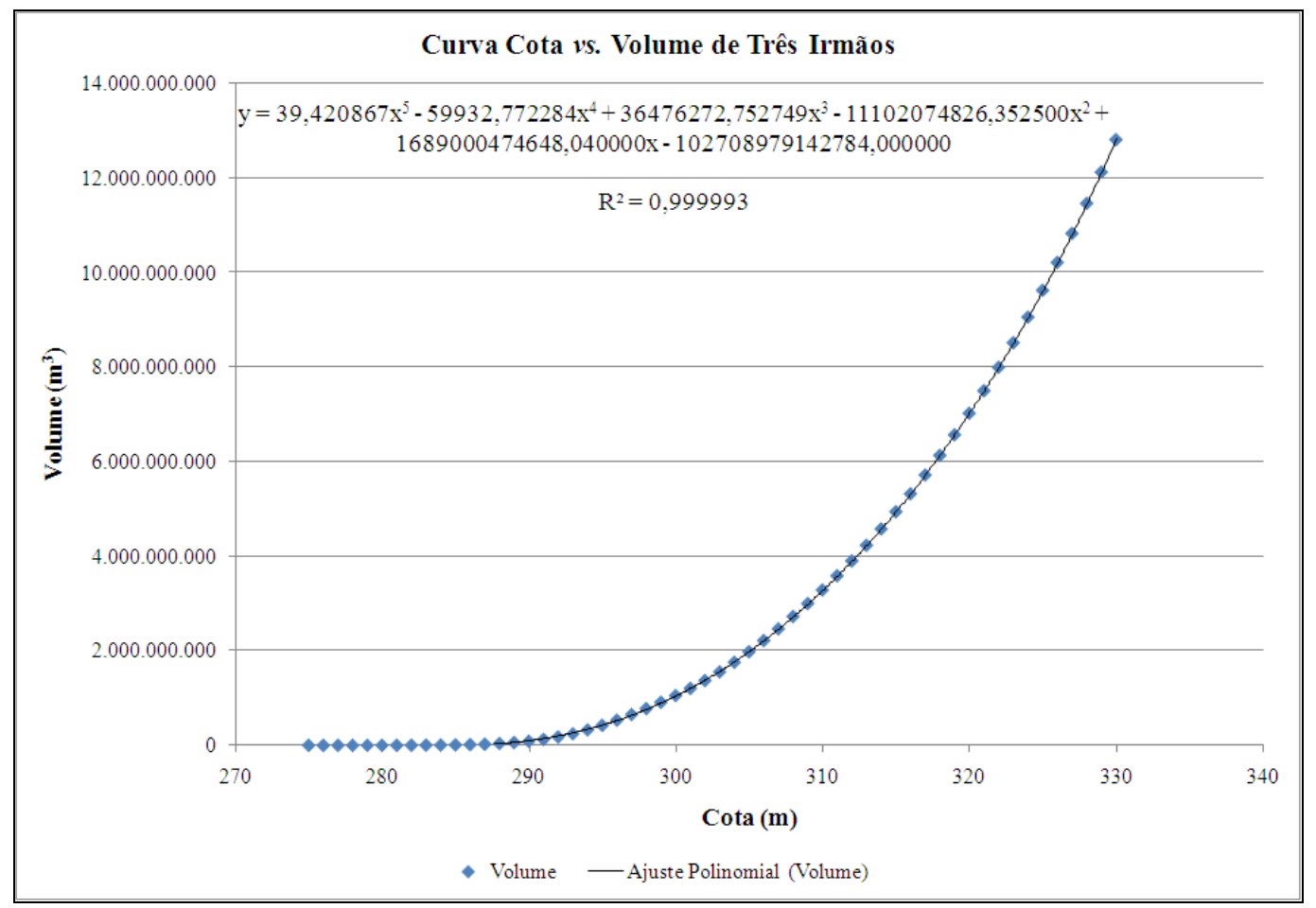

Figura 15. Curva e polinômio cota vs. volume do reservatório obtido a partir da batimetria. Fonte: FIPAI (2009). 


\subsubsection{Extrapolação dos dados do reservatório para simulação da sua operação}

Em decorrência da pouca quantidade de dados disponíveis e do intervalo de tempo entre estes dados (1975 e 2008), para que houvesse um melhor entendimento do problema do assoreamento na questão da geração de energia, foi necessário analisar qual a taxa de assoreamento deste período e extrapolar dados para este intervalo de tempo.

Assim, a partir dos dados disponíveis, verificou-se a taxa de assoreamento registrado durante o período de 1975 a 2008 e adotou-se o crescimento gradual e linear do assoreamento para definição, simulação e análise da evolução do assoreamento neste período. Esta metodologia foi empregada para que as análises não adotassem o assoreamento como um processo integral e instantâneo se considerado apenas os dados de 1975 e 2008. Desse modo, pôde-se distribuir a taxa de assoreamento registrado entre os dados da CESP e da batimetria e encontrar valores extrapolados mais próximos dos verificados na realidade (para o intervalo de 1993 a 2008).

A partir dessa metodologia foi possível analisar a operação do reservatório entre o período de 1993 (início da operação da primeira turbina da UHE) a 2008. As principais modificações entre os dados do reservatório neste período foram quanto aos valores de área e volume do reservatório, que foram alterados com o passar do tempo devido ao assoreamento. Estes dados foram inseridos no software AcquaNet para determinação da energia que seria produzida em cada período. 


\subsection{Software AcquaNet}

O programa AcquaNet utilizado nesta pesquisa é uma modificação do software MODSIM. O software MODSIM foi desenvolvido por John W. Labadie (1988) na Universidade do Colorado, nos Estados Unidos. As alterações no MODSIM foram realizadas no Laboratório de Sistemas de Suporte a Decisão (LabSid) da Escola Politécnica da Universidade de São Paulo, através de aprimoramentos em sua interface gráfica e em seu sistema de gerenciamento de dados, com a criação e utilização de bancos de dados no formato Microsoft Access® (LERNER, 2006).

A linguagem de programação do MODSIM também foi alterada da sua versão original que era Fortran para Visual Basic ${ }$. Conforme ocorriam modificações e aperfeiçoamentos no MODSIM, surgiam novas denominações para o software como MODSIMP32, MODSIMLS e finalmente AcquaNet (ALBANO, 2004).

O AcquaNet tem seu princípio de funcionamento baseado nos modelos de rede de fluxo e é utilizado para simulação de bacias hidrográficas (PORTO e ROBERTO, 2002). Este software surgiu para dar suporte à tomada de decisão no planejamento e gerenciamento de recursos hídricos. Para tanto, o AcquaNet utiliza um algoritmo de balanço de massa para simulação e o algoritmo "Out-of-Kilter" para otimização dos sistemas (PORTO et al., 2003).

Deste modo, além do software poder ser utilizado para planejamento e gerenciamento de um sistema hídrico, o mesmo também pode ser utilizado para avaliar e administrar conflitos entre os usuários do sistema, principalmente em períodos de escassez hídrica, e também pode ser usado para avaliar projetos ou alterações na operação de reservatórios, represas, rios, entre outros. 
De acordo com Azevedo et al. (1997), os principais atributos deste programa são:

- Realizar a simulação de volumes hídricos armazenados (em represas e reservatórios) e a distribuição de vazões de um sistema de recursos hídricos, com intervalos de tempo semanal ou mensal;

- Otimizar a operação de sistemas de recursos hídricos através de algoritmos desenvolvidos para a solução de problemas de minimização de custo que não necessariamente precisam ser monetários;

- Formulação de diretrizes operacionais de curto prazo (semanal) ou de longo prazo (sazonal ou plurianual).

Os mesmos autores ressaltam que a combinação entre os métodos de simulação e otimização é muito importante para extrair as principais vantagens de cada método e tornar o software mais eficiente quando comparado a maioria dos modelos disponíveis que utilizam apenas a simulação.

Conforme Roberto e Porto (1999) destacam, que o software utilizado neste trabalho apresenta outros atributos importantes para simulação de sistemas hídricos, como: possibilidade de adicionar inúmeros nós de demandas; relacionar as perdas por evaporação dos reservatórios; realizar o balanço hídrico superficial e subterrâneo e calcular a produção de energia elétrica.

Como o AcquaNet é baseado nos modelos de rede de fluxo, o seu princípio de funcionamento é representar um sistema de recurso hídrico através de uma sucessão de arcos e nós. Conforme descrito anteriormente, os nós representam os elementos mais estáticos do sistema, ou seja, os pontos de entrada e saída dos fluxos (reservatórios, demandas, entre 
outros) e os arcos representam os elementos mais dinâmicos do sistema (rios, canais, dutos, entre outros), onde ocorre o transporte dos fluxos.

Deste modo, o AcquaNet executa seus cálculos levando em consideração que a rede de fluxo analisada é uma rede pura, ou seja, apresenta as seguintes características (ROBERTO e PORTO, 2001; ROBERTO, 2002):

- A rede necessita ser capacitada, isto é, os fluxos em cada arco são restringidos por uma capacidade de transporte mínima e máxima (ou inferior e superior), conforme Equação 1.

$I_{i j} \leq Q_{i j} \leq S_{i j}$ Equação 1

Em que:

$\mathrm{I}_{\mathrm{ij}}$ : limite inferior da vazão no arco i,j;

$\mathrm{Q}_{\mathrm{ij}}$ : vazão que transita do nó i ao nó j;

$S_{\mathrm{ij}}$ : limite superior da vazão no arco i,j.

- A rede precisa ser conservativa ou circulante, ou seja, o somatório dos fluxos que chegam a um nó é igual à soma dos fluxos que saem deste nó (Equação 2).

$\sum Q_{i j}=\sum Q_{j k}$

Equação 2

Em que:

$\mathrm{Q}_{\mathrm{ij}}$ : vazão que transita do nó i ao nó j;

$\mathrm{Q}_{\mathrm{jk}}$ : vazão que transita do nó $\mathrm{j}$ ao nó $\mathrm{k}$; 
- Cada arco do sistema pode ser associado a um custo para transporte do fluxo (Equação 3), sendo que este custo não precisa ser necessariamente monetário.

$C_{i j} \cdot Q_{i j}$

Equação 3

Em que:

$\mathrm{C}_{\mathrm{ij}}$ : custo (prioridade) da unidade de vazão que transita entre os nós i e j;

$\mathrm{Q}_{\mathrm{ij}}$ : vazão que transita do nó i ao nó j;

Deste modo, neste software a função objetivo é minimizar o custo do transporte dos fluxos pelos arcos (Equação 4), respeitando as condições descritas anteriormente, rede capacitada (Equação 5) e rede conservativa (Equação 6), conforme a formulação apresentada a seguir (PORTO et al., 2003):

$\min \sum_{i=1}^{n} \sum_{j=1}^{n} C_{i j} \cdot Q_{i j}$

Equação 4

sujeito a:

$\sum Q_{i j}-\sum Q_{j k}=0$

Equação 5

para cada nó e

$I_{i j} \leq Q_{i j} \leq S_{i j}$

Equação 6

para cada arco.

Em que:

$\mathrm{C}_{\mathrm{ij}}$ : custo (prioridade) da unidade de vazão que transita entre os nós i e j;

$\mathrm{Q}_{\mathrm{ij}}$ : vazão que transita do nó i ao nó j; 
$\mathrm{Q}_{\mathrm{jk}}$ : vazão que transita do nó j ao nó k;

$\mathrm{I}_{\mathrm{ij}}$ : limite inferior da vazão no arco i,j;

$\mathrm{S}_{\mathrm{ij}}$ : limite superior da vazão no arco i,j;

n: número total de nós da rede.

A partir da formulação anterior, percebe-se que o problema a ser resolvido é uma típica representação de programação linear que no caso do AcquaNet é resolvida por meio do algoritmo denominado "Out-of-Kilter", que foi desenvolvido especialmente para resolver problemas de minimização de custos em redes de fluxo (AZEVEDO et al., 1997; BAZARAA et al., 1977).

Além do AcquaNet/MODSIM este algoritmo também é utilizado em vários outros modelos de redes de fluxos, como: SIMTLD (Evanson e Mosley, 1970 apud Yeh, 1985), ACRES (Sigvaldason, 1976 apud Yeh, 1985), WASP (Kuczuera e Diment, 1988 apud Yeh, 1985), DWRSIM (Chung et al. 1989 apud Yeh, 1985) e CRAM (Brendecke et al., 1989 apud Yeh, 1985), entre outros (PORTO et al., 2003).

Desse modo, a partir da elaboração e da representação do sistema no AcquaNet, ocorrem os cálculos e a simulação do sistema, onde através do algoritmo de otimização, define-se a melhor maneira para distribuição hídrica, a partir da disponibilidade, da demanda e dos demais dados de entrada do modelo.

Outro fato que merece ser destacado a respeito do AcquaNet é quanto a sua estrutura modular. O software é composto por um módulo base e outros módulos independentes que realizam ações específicas: avaliação da qualidade da água, cálculo de alocação de água, alocação de água para irrigação, valoração econômica de decisão de alocação e produção de energia elétrica. 
A estrutura do programa e uma breve descrição de seus módulos são apresentadas na Figura 16, com destaque ao módulo de energia que é utilizado nesta pesquisa.

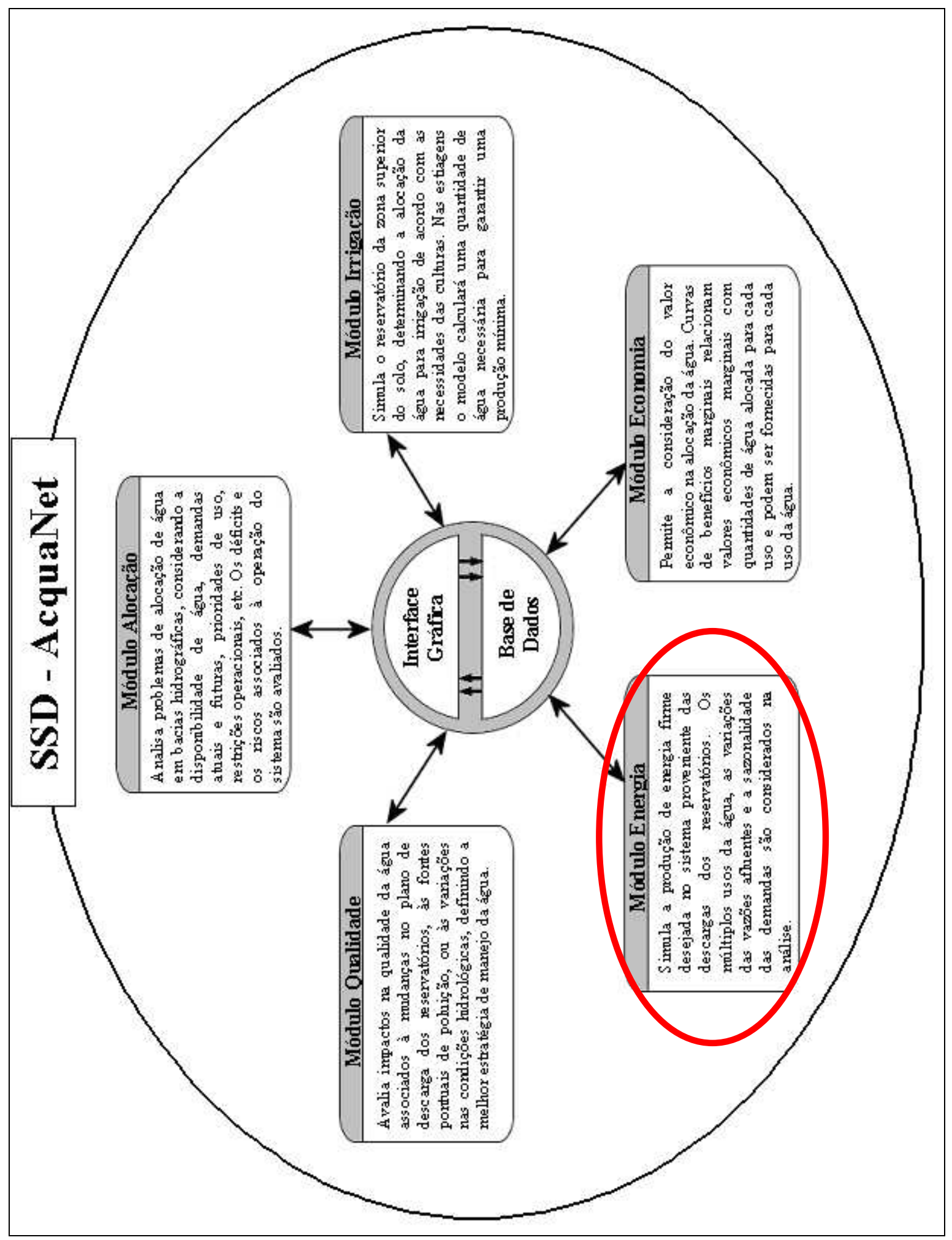

Figura 16. Estrutura do AcquaNet com destaque ao módulo de energia.

Fonte: Porto et al. (2003). 
A partir dos módulos do AcquaNet e das suas inúmeras possibilidade de aplicação, Roberto (2002) exemplifica e apresenta a utilização do software para algumas situações, como:

- Determinação do volume máximo de reservatórios;

- Análise e determinação da garantia de atendimento à demanda hídrica;

- Determinação da curva-guia para operação de sistemas hídricos;

- Análise de um sistema hídrico sob o aspecto da geração de energia.

PORTO et al. (1999) citam a utilização do AcquaNet como parte de um sistema suporte a decisão utilizado pela Companhia de Saneamento Básico do Estado de São Paulo SABESP.

Albano (2004) menciona a importância da análise quali-quantitativa dos recursos hídricos e em seu trabalho desenvolveu uma metodologia para a integração de dois modelos matemáticos, sendo um para quantidade de água (AcquaNet) e outro para análise da qualidade de água, denominado CE-QUAL-R1 ${ }^{27}$. Esta metodologia foi aplicada à Represa JaguariJacareí como alternativa ao gerenciamento quali-quantitativo do local.

Outro estudo referente ao AcquaNet é apresentado em Lerner (2006), que analisou o impacto da transposição de águas do Rio São Francisco na geração hidrelétrica. Para tanto, o autor utilizou diferentes valores de vazão para verificar qual seria a produção de energia e simular e analisar os impactos da transposição do rio na geração de energia.

Maia (2006) também utilizou o software AcquaNet para analisar a interferência da variação do volume útil do Reservatório de Promissão (UHE Mário Lopes Leão) na geração de energia elétrica da usina. Neste estudo, a autora pôde constatar uma redução significativa

\footnotetext{
${ }^{27}$ CE-QUAL-R1: Modelo matemático desenvolvido pelo U.S. Army Corps of Engineers.
} 
na geração de energia média mensal no período de estiagem, para um cenário estimado de 130 $\operatorname{anos}(1975-2105)$.

Por fim, cabe ressaltar que além dos trabalhos citados anteriormente, encontram-se na literatura inúmeros outros materiais, com informações sobre a operação e o funcionamento do software AcquaNet.

\subsubsection{Módulo de produção de energia elétrica}

O módulo de produção de energia tem como finalidade simular a geração de energia firme das usinas hidrelétricas levando em consideração as características aleatórias das vazões afluentes as usinas, as variações das demandas energéticas e os usos múltiplos da água, entre outros (AZEVEDO et al., 1997).

Os cálculos que são realizados neste módulo (para simulação da geração de energia) são baseados na Equação 7 e ilustrados pela Figura 17 (PORTO et al., 2003).

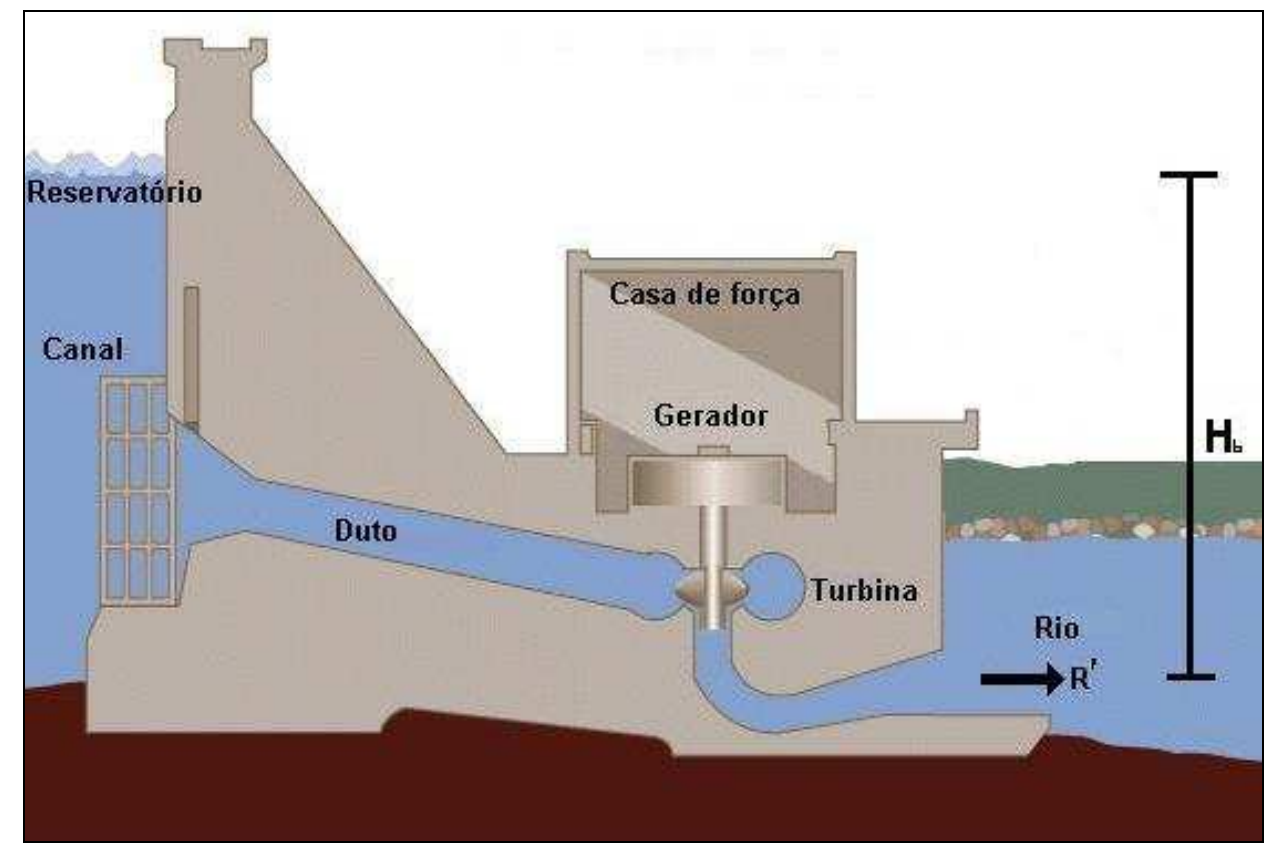

Figura 17. Ilustração simplificada de uma usina hidrelétrica.

Fonte: Adaptada de WIKIMEDIA (2010). 
$P=\rho \cdot g \cdot \eta \cdot H_{b} \cdot R^{\prime}$

Equação 7

Em que:

P: potência gerada (MW);

$\rho:$ peso específico da água $\left(10^{3} \mathrm{~kg} / \mathrm{m}^{3}\right)$;

g: aceleração da gravidade $\left(9,81 \mathrm{~m} / \mathrm{s}^{2}\right)$;

ๆ: rendimento médio total da usina - conjunto turbina-gerador e perda do sistema hidráulico de carga (adimensional);

$\mathrm{H}_{\mathrm{b}}$ : queda bruta $(\mathrm{m})$;

R': vazão turbinada $\left(\mathrm{m}^{3} / \mathrm{s}\right)$.

Deste modo, pode-se observar através da Equação 7, que com a simulação realizada pelo AcquaNet, pode-se obter a potência gerada a partir, basicamente, da queda bruta da usina e da vazão turbinada.

O módulo de produção de energia examina as restrições operacionais da UHE conforme descrito nas Equações 8 e 9 (PORTO et al., 2003).

$$
R_{\text {min }}^{\prime} \leq R^{\prime} \leq R_{\text {max }}^{\prime} \cdot I D
$$

Equação 8

\section{Em que:}

$\mathrm{R}_{\text {min: }}$ turbinagem mínima das máquinas da $\operatorname{UHE}\left(\mathrm{m}^{3} / \mathrm{s}\right)$;

$\mathrm{R}^{\prime}$ : vazão turbinada nas máquinas da $\operatorname{UHE}\left(\mathrm{m}^{3} / \mathrm{s}\right)$;

$\mathrm{R}_{\text {max }}$ : turbinagem máxima das máquinas da $\operatorname{UHE}\left(\mathrm{m}^{3} / \mathrm{s}\right)$;

ID: índice de disponibilidade ${ }^{28}$ das máquinas (adimensional).

\footnotetext{
${ }^{28} \mathrm{O}$ índice de disponibilidade refere-se a estimativa de tempo que a máquina opera.
} 
$P_{\max } \leq P_{\text {inst }} \cdot I D$

Equação 9

Em que:

$\mathrm{P}_{\max }$ : potência máxima gerada pela UHE (MW);

$P_{\text {inst: }}$ potência instalada na UHE (MW).

Outro fato que merece ser destacado é quanto à entrada de dados tanto, no programa AcquaNet, quanto no módulo de geração de energia. O programa requer uma série de dados para processamento das simulações e os resultados gerados estão vinculados diretamente à disponibilidade e credibilidades dos dados inseridos no mesmo.

Os principais dados de entrada deste módulo são:

- Características físicas do reservatório (como os dados de cota $v s$. área $v s$. volume e os volumes: máximo, mínimo, $\operatorname{meta}^{29}$ );

- Vazões naturais afluentes e taxa de evaporação do reservatório;

- Potência total instalada na UHE;

- Número de turbinas e índice de disponibilidade das máquinas da UHE;

- Rendimento do conjunto turbina-gerador da UHE;

- Engolimento mínimo e curva de engolimento máximo por turbina;

- $\quad$ Curva-chave ${ }^{30}$ a jusante da UHE.

A partir dos dados de entrada, o programa realiza os cálculos e apresenta os resultados na forma de gráficos e planilhas, conforme será apresentado no próximo capítulo. Entre os resultados que podem ser obtidos neste módulo pode-se destacar: os valores médios mensais de vazão turbinada pela UHE, o nível d'água do reservatório e a potência mensal gerada na UHE, entre outros.

\footnotetext{
${ }^{29}$ Volume adotado na operação do reservatório para garantir o atendimento das suas demandas.

30 A curva-chave é uma função não-linear que representa a relação entre nível e vazão. Fonte: http://www.iph.ufrgs.br/posgrad/disciplinas/hip01/apresentacoes/capitulo11.ppt.
} 


\section{RESULTADOS E DISCUSSÕES}

\subsection{Simulação da operação do reservatório e da usina - AcquaNet}

Conforme descrito anteriormente, o AcquaNet é um software que tem seu princípio de funcionamento baseado nos modelos de rede de fluxo sendo utilizado para simulação de bacias hidrográficas. Este software permite a representação de forma bem detalhada dos sistemas de recursos hídricos, através de uma rede formada por nós e arcos.

A tela principal do programa AcquaNet é destinada para representação do sistema que será analisado, e apresenta as ferramentas para construção e edição da rede que melhor representam o sistema.

A representação do Reservatório de Três Irmãos e das suas principais demandas, adotada neste trabalho para simulação da operação do reservatório no programa AcquaNet é apresentada na Figura 18. Esta estruturação foi definida a partir de informações fornecidas pela concessionária de energia que administra a usina CESP (2010).

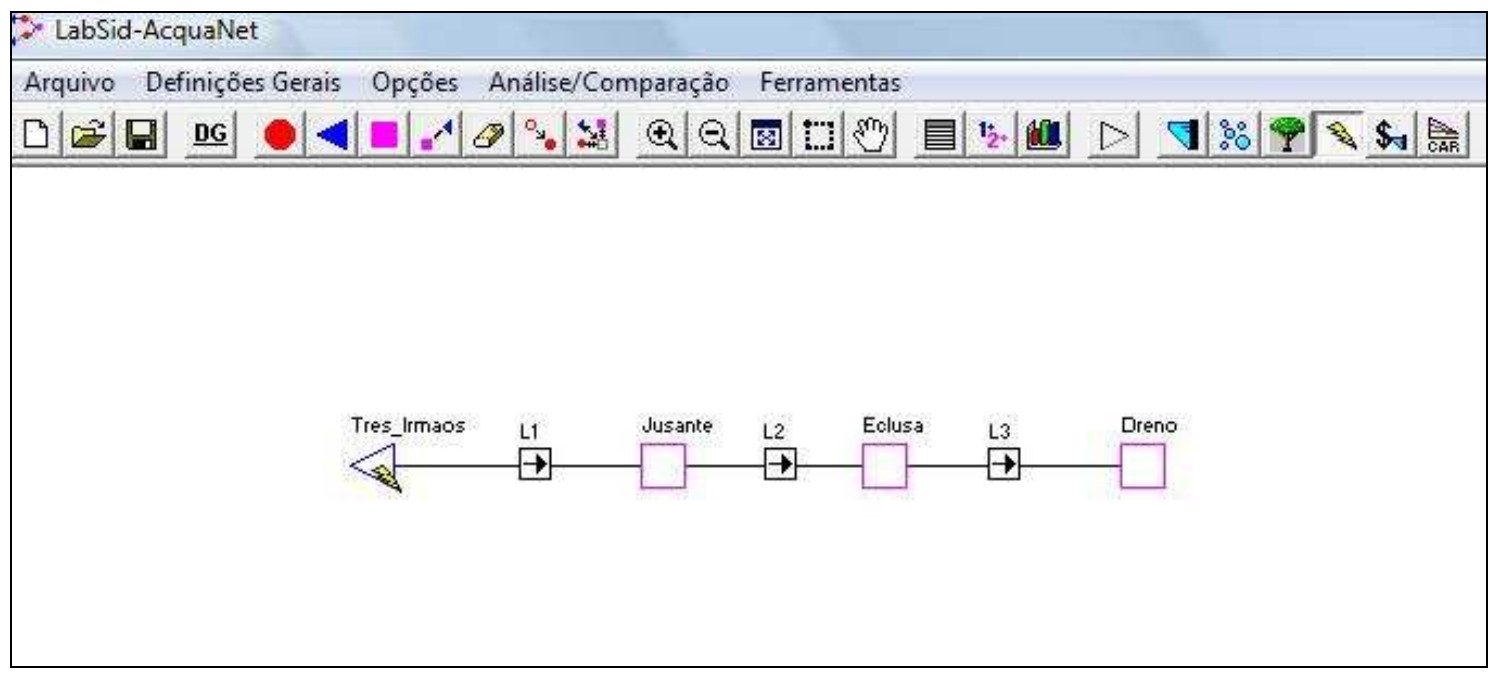

Figura 18. Representação no AcquaNet do Reservatório de Três Irmãos e das suas principais demandas. 
Como é possível verificar na Figura 18, a simulação do reservatório teve como principais demandas:

- Jusante: representa a vazão mínima mensal praticada para fins operativos e garantida a jusante da UHE. Segundo CESP (2010) este valor corresponde a $330 \mathrm{~m}^{3} / \mathrm{s}$;

- Eclusa: representa a vazão mensal utilizada no sistema de eclusagem do reservatório. O valor desta demanda foi obtido a partir de dados fornecidos pela CESP (2010) e corresponde a aproximadamente $0,3 \mathrm{~m}^{3} / \mathrm{s}$.

- Dreno: representa uma demanda artificial que é utilizada no final da rede para receber todo o excesso de água e impedir o extravasamento do reservatório. O valor mensal adotado para esta demanda foi de $2.000 \mathrm{~m}^{3} / \mathrm{s}$.

Neste ponto, cabe destacar que a demanda exigida pelo Canal de Pereira Barreto (transposições hídricas entre os reservatórios das UHEs de Ilha Solteira e Três Irmãos), assim como as outras demandas consuntivas do reservatório (abastecimento urbano, industrial, rural, entre outros), foram descontadas nos valores das vazões afluentes ao reservatório (Tabela 6) como será possível observar posteriormente.

Além da definição dos valores de cada demanda, também foram determinados os seus valores de prioridade de atendimento (Tabela 11). Estes valores são importantes, pois determinam a ordem de atendimento das demandas e quais serão atendidas em caso especiais, como déficit hídrico em períodos de estiagem, onde pode haver momentos que apresentam disponibilidades hídricas inferiores às demandas requeridas pelo sistema. 
Tabela 11. Principais demandas do reservatório e suas prioridades de atendimento.

\begin{tabular}{|l|c|}
\hline Demanda & Prioridade \\
\hline Geração de energia elétrica & 1 \\
\hline Jusante & 10 \\
\hline Eclusa & 20 \\
\hline Volume meta & 30 \\
\hline Dreno & 99 \\
\hline
\end{tabular}

As prioridades foram determinadas a partir de informações recebidas pela concessionária de energia e bibliografias referentes ao software AcquaNet. As prioridades deveriam receber valores entre 1 (prioridade máxima) e 99 (prioridade mínima), que são os valores aceitos pelo software.

Como é possível observar na Tabela 11, a geração de energia elétrica recebeu a prioridade máxima para atendimento, seguida das demandas de jusante, eclusagem, volume meta e dreno. A demanda fictícia dreno que foi adicionada artificialmente para impedir o extravasamento do reservatório recebeu a prioridade mínima (99) para não competir com as outras demandas reais do sistema. A demanda dreno é utilizada para representar o escoamento da água que não é aproveitada pelo sistema e não pode ser armazenada no reservatório.

Os dados de entrada do software para simulação do reservatório e da usina hidrelétrica no período proposto neste trabalho (1993 a 2008) são apresentados a seguir.

As figuras 19 e 20 apresentam os dados de entrada com as características físicas do reservatório, como os dados de cota vs. área vs. volume, volume máximo, mínimo e inicial. A Figura 19 apresenta os dados utilizados para simulação do reservatório em 1993 (data do início da operação da primeira turbina da UHE) e a Figura 20 apresenta os dados empregados para simulação do reservatório em 2008.

É importante destacar que, além dos dados apresentados nas figuras 19 e 20, também foram utilizados outros dados para simulação do reservatório no intervalo de 1993 a 2008. Como citado anteriormente, tanto os dados do reservatório de 1993 quanto do intervalo até 2008 foram estimados a partir da extrapolação dos dados disponíveis da CESP (1975) e do 
levantamento batimétrico (2008). As únicas alterações nos dados de entrada do software AcquaNet que não foram apresentadas nesta dissertação, mas que foram utilizadas para a simulação da operação do reservatório em outras datas, devem-se aos dados de cota vs. área vs. volume do reservatório e seus respectivos volumes: máximo, mínimo e inicial. Assim, torna-se evidente que as variações encontradas nos resultados das simulações do reservatório para as diferentes datas (ou seja, variações na produção de energia) foram decorrentes do processo de assoreamento do reservatório, que causaram modificações em seus dados de cota vs. área $v s$. volume.

\begin{tabular}{|c|c|c|c|c|c|}
\hline \multicolumn{4}{|c|}{ \#- Dados do Reservatório Tres_Irmaos } & \multicolumn{2}{|c|}{0 回 } \\
\hline \multicolumn{2}{|c|}{ Energia: Prioridade / Potência } & \multicolumn{2}{|c|}{ Energia: dados para geração } & & \\
\hline \multicolumn{2}{|l|}{ Características físicas } & \multicolumn{2}{|c|}{ Prioridade / Volume Meta } & \multicolumn{2}{|c|}{ Vazão natural / Evaporação } \\
\hline \multicolumn{3}{|l|}{ Identificação } & \multicolumn{3}{|c|}{ Tabela Cota-Area-Volume } \\
\hline \multirow[t]{2}{*}{ Nome do reservatório: } & \multirow{2}{*}{\multicolumn{2}{|c|}{ Tres_limaos }} & Cota $[m]$ & Area $\left[\mathrm{km}^{2}\right]$ & Volume $\left(\mathrm{Mm}^{3}\right)$ \\
\hline & & & 280,000 & 0.000 & 0,000 \\
\hline \multicolumn{3}{|l|}{ Volumes característicos } & 285,000 & 4,905 & 13,489 \\
\hline \multirow{2}{*}{ Volume máximo $\left(\mathrm{Mm}^{3}\right)$ : } & \multirow{2}{*}{\multicolumn{2}{|c|}{12304,070}} & 290,000 & 33,816 & 106,186 \\
\hline & & & 295,000 & 108,386 & 462,526 \\
\hline \multirow[t]{2}{*}{ Volume mínimo $\left(\mathrm{Mm}^{3}\right)$ : } & \multirow{2}{*}{\multicolumn{2}{|c|}{9136,010}} & 300,000 & 161,174 & 1139,894 \\
\hline & & & 305,000 & 243,289 & 2142,695 \\
\hline \multirow[t]{2}{*}{ Volume inicial ( $\left(\mathrm{Mm}^{3}\right)$ : } & \multicolumn{2}{|c|}{12304,070} & 310,000 & 314,040 & 3534,754 \\
\hline & & & 315,000 & 397,181 & 5309,420 \\
\hline \multirow{3}{*}{\multicolumn{3}{|c|}{$\begin{array}{l}\text { Energia elétrica } \\
\sqrt{V} 0 \text { Reservatório é usina hidroelétrica }\end{array}$}} & 320,000 & 496,277 & 7537,303 \\
\hline & & & 323,000 & 570,238 & 9136,010 \\
\hline & & & 324,000 & 596,057 & 9719,160 \\
\hline \multirow[t]{10}{*}{ Nó destino da vazão turninada: } & \multirow[t]{2}{*}{ Jusante } & \multirow[t]{2}{*}{$\mp$} & 325,000 & 621,553 & 10327,960 \\
\hline & & & 326,000 & 646,150 & 10961,820 \\
\hline & & & 327,000 & 671,043 & 11620,410 \\
\hline & & & 328,000 & 696,276 & 12304,070 \\
\hline & & & 329,000 & 721.857 & 13013,130 \\
\hline & & & 330,000 & 747,789 & 13747,960 \\
\hline & & & 0,000 & 0,000 & 0,000 \\
\hline & & & 0,000 & 0,000 & 0,000 \\
\hline & & & 0,000 & 0,000 & 0,000 \\
\hline & & & & & Can \\
\hline
\end{tabular}

Figura 19. Janela de configuração do AcquaNet - Características físicas do reservatório para o cenário de 1993. 


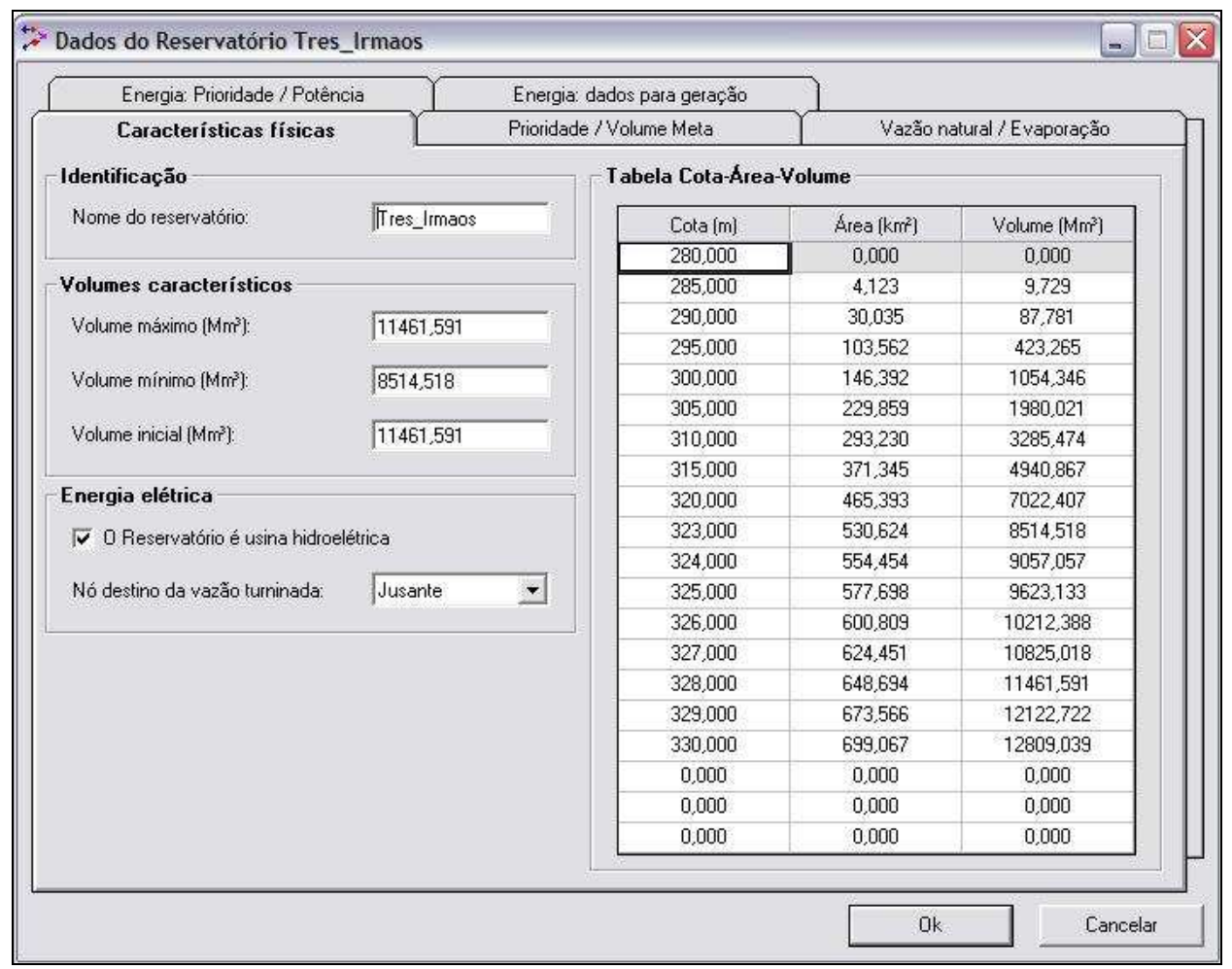

Figura 20. Janela de configuração do AcquaNet - Características físicas do reservatório para o cenário de 2008.

Neste ponto, é relevante destacar que os dados inseridos nas outras janelas de configuração do AcquaNet (conforme apresentados a seguir) são idênticos, ou seja, não sofreram alterações de uma simulação para a outra, por se tratar de dados técnicos ou operacionais da usina e do reservatório.

A Figura 21 apresenta o valor de prioridade e dos volumes metas adotados para o reservatório. Estes valores foram determinados com base em outros estudos realizados e materiais disponíveis na literatura sobre o software AcquaNet.

Conforme Carvalho et al. (2009) descrevem, o conceito de nível ou volume meta tem como objetivo estabelecer valores (de acordo com as disponibilidades hídricas do reservatório) de indicação para decisão de alocação de água no reservatório, ou seja, sempre que o volume armazenado no reservatório for menor que o volume meta, o reservatório deverá armazenar água, desde que respeite as ordens de prioridades de atendimento das demais demandas do sistema. 


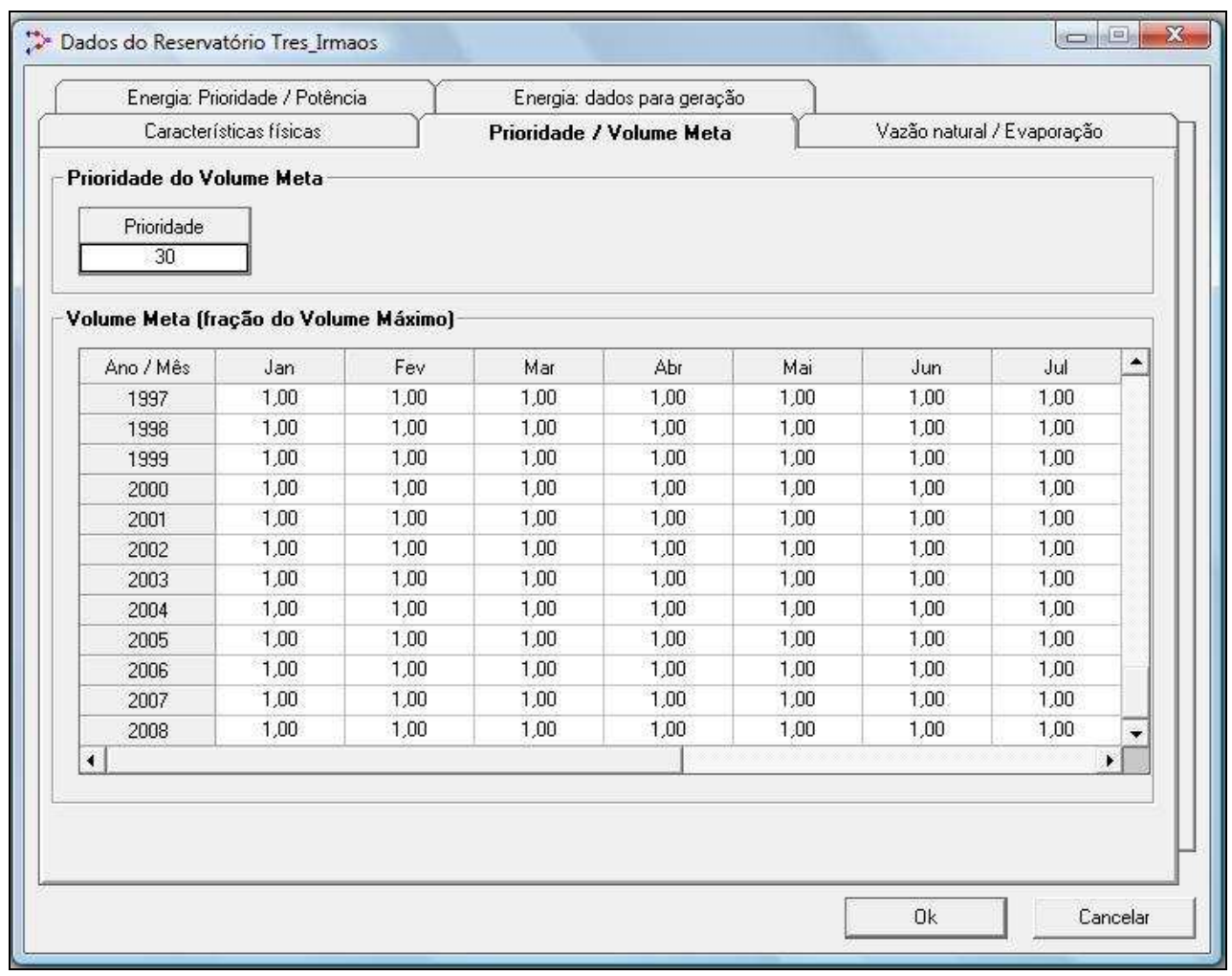

Figura 21. Janela de configuração do AcquaNet - Prioridade/Volume meta.

As vazões afluentes ao Reservatório de Três Irmãos, utilizadas nas simulações, foram obtidas a partir dos dados disponíveis em ONS (2010) e apresentados anteriormente na Tabela 6. A série de vazão corresponde ao período de 1931 a 2008 e, como citado anteriormente, teve descontado os valores relativos às demandas consuntivas requeridas do reservatório. Estas demandas são referente ao abastecimento (urbano, industrial, rural), irrigação, aquicultura, entre outros. Segundo CESP (2010), este valor (consumo mensal para fins consuntivos do reservatório) corresponde a aproximadamente $63 \mathrm{~m} 3 / \mathrm{s}$.

A Figura 22 apresenta a variação das vazões anuais afluentes ao reservatório para o período de 1975 a 2008 (ONS, 2010) e, através desta figura, pode-se observar que existe uma grande variação de vazão efluente ao reservatório de um período para o outro. 


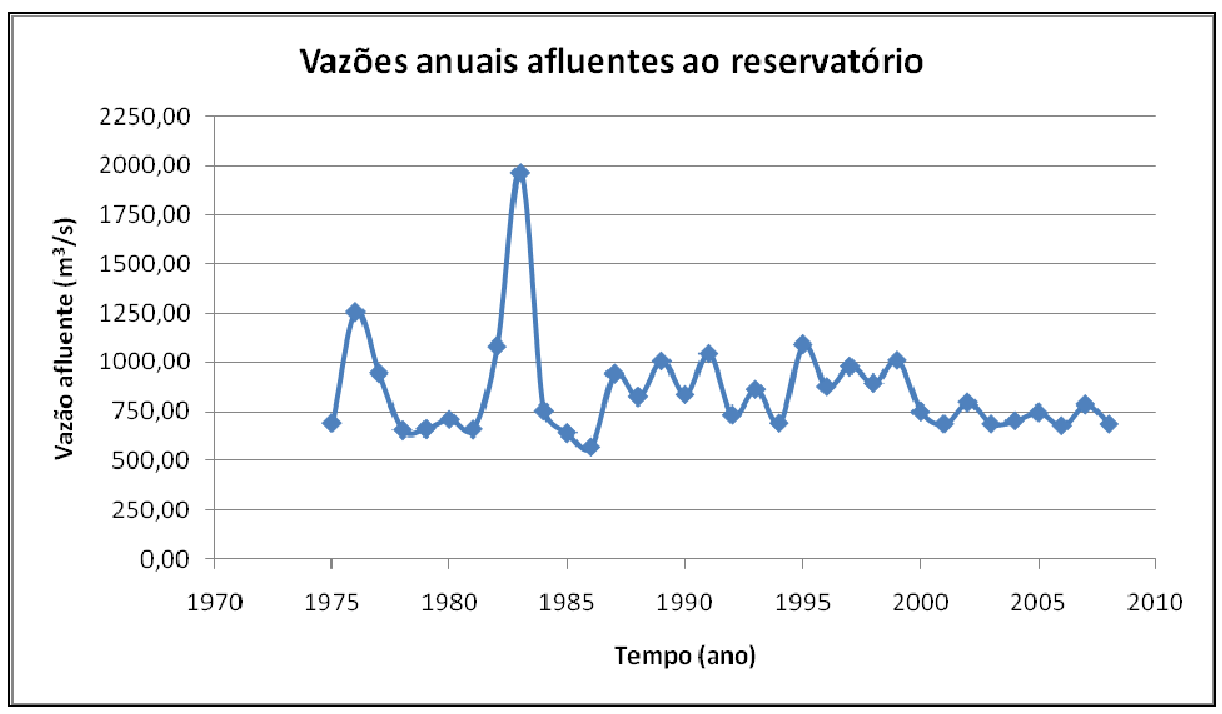

Figura 22. Vazão anual afluente ao Reservatório de Três Irmãos no período de 1975 a 2008.

Na Figura 23 são apresentados os valores das vazões afluentes ao reservatório (descontadas as demandas consuntivas) e as taxas de evaporação do reservatório (Tabela 7) que foram inseridos no software AcquaNet.

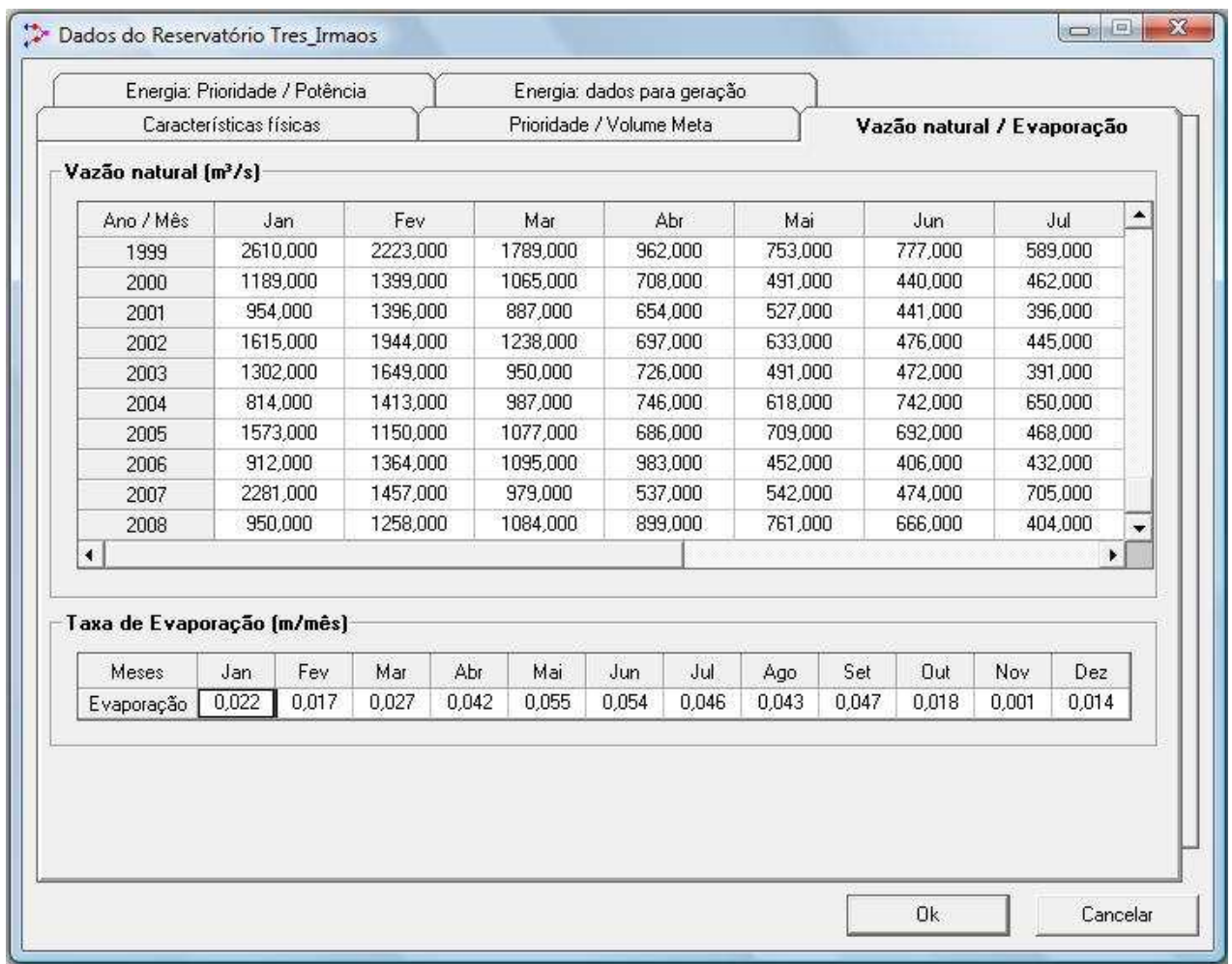

Figura 23. Janela de configuração do AcquaNet - Vazões naturais e taxas de evaporação. 
O próximo passo para a análise e simulação da operação do reservatório foi a escolha do módulo secundário do AcquaNet, que no caso deste estudo, foi o módulo de produção de energia elétrica. Este módulo requer dados relativos às especificações técnicas e operativas da usina hidrelétrica.

Na Figura 24 são apresentados os dados de potência mensal desejada, que no caso deste trabalho, foram definidos a partir da média dos valores fornecidos pela CESP referentes a produção de energia que foi registrada entre 2000 e 2009. A adoção dos valores médios de energia gerada em cada mês teve como intenção tornar a simulação da geração de energia mais próxima dos valores atuais encontrados pela concessionária de energia que administra a UHE.

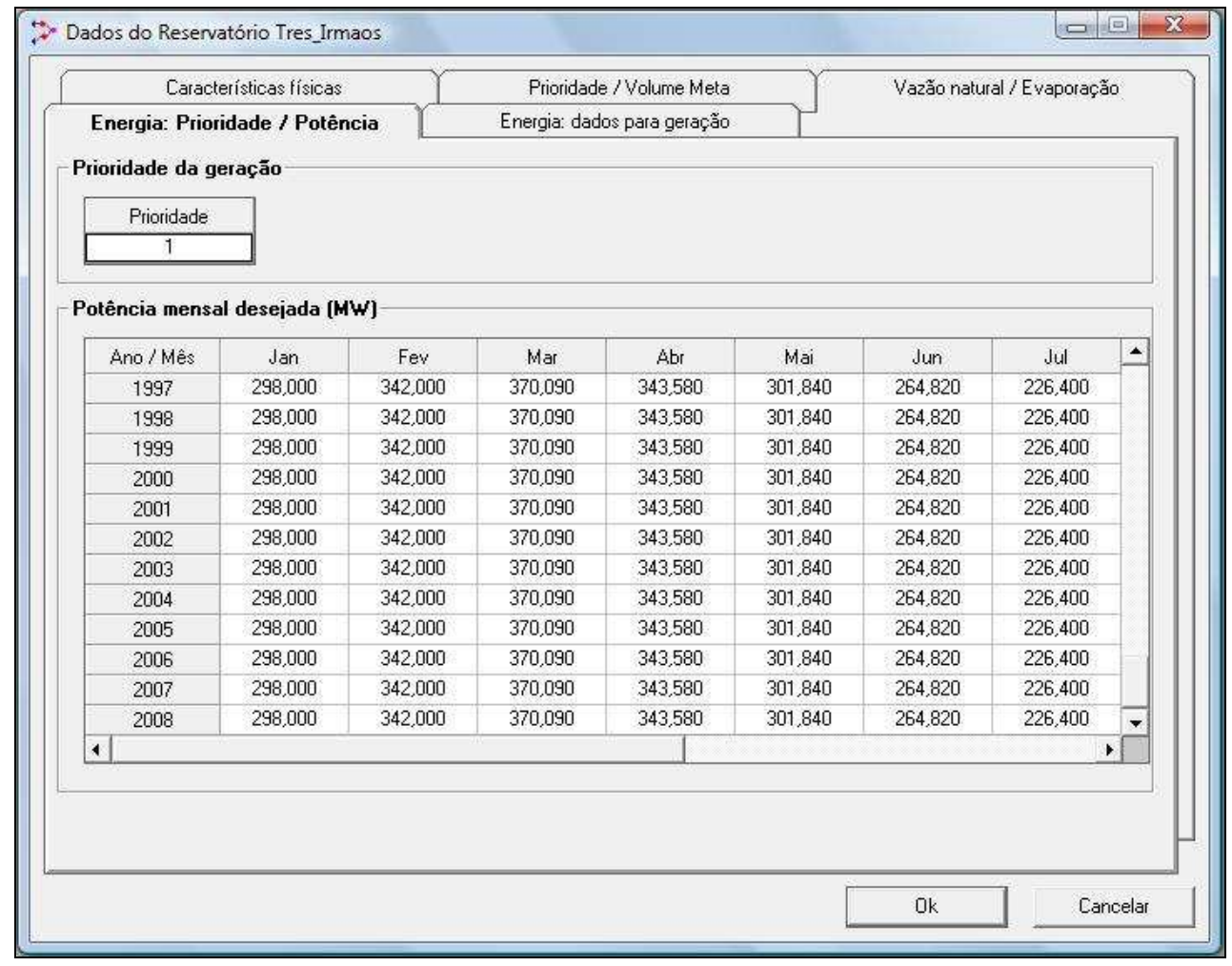

Figura 24. Janela de configuração do AcquaNet - Energia: prioridade da geração e potência mensal desejada. 
A Figura 25 apresenta os principais dados técnicos e operativos, referentes a usina hidrelétrica, que são exigidos pelo AcquaNet para realização das simulações, tais como: potência total instalada, rendimento do conjunto turbina-gerador, número de turbinas, índice de disponibilidade das máquinas, engolimento mínimo e máximo da turbinas e curva-chave de jusante. Todos estes dados foram fornecidos pela CESP.

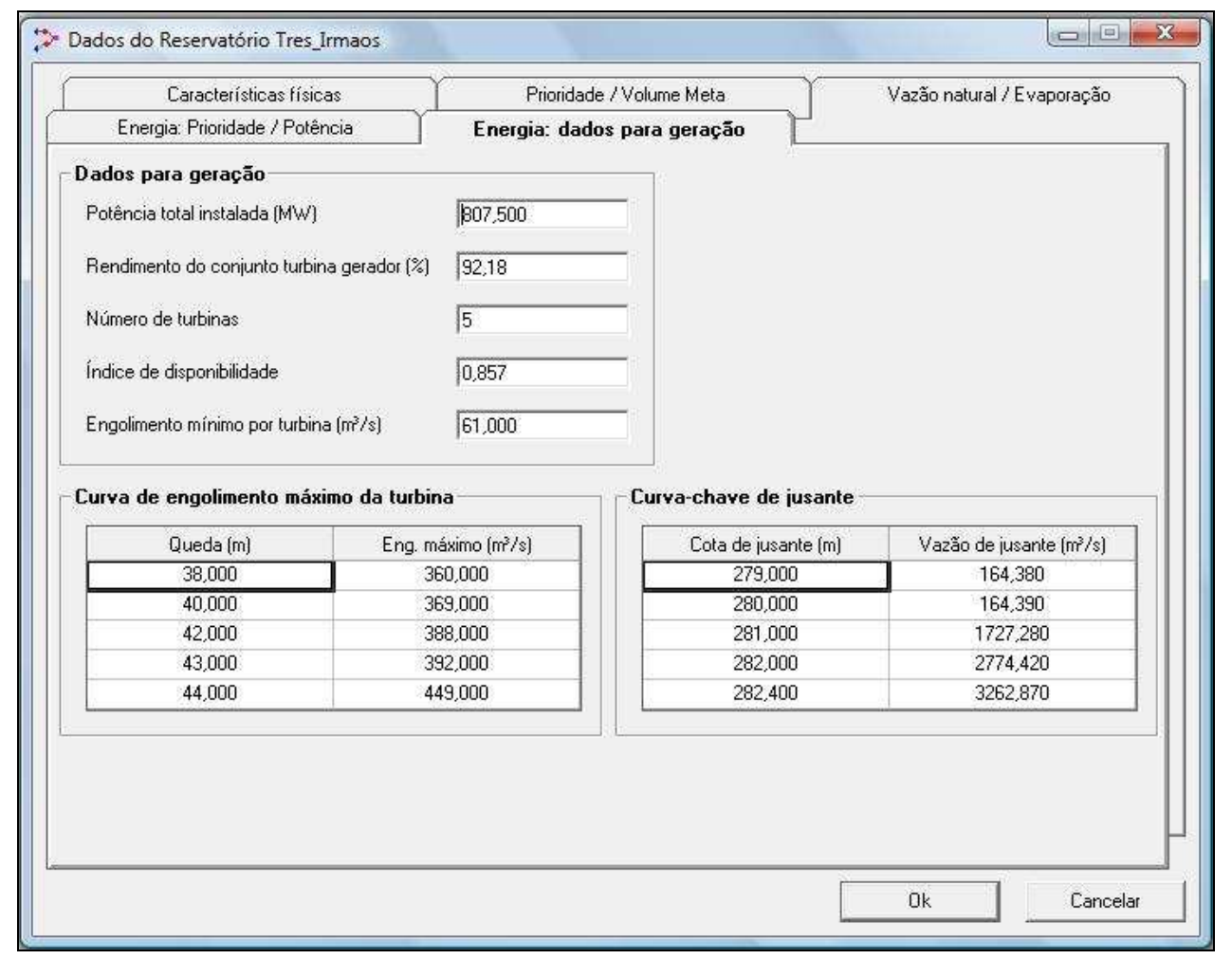

Figura 25. Janela de configuração do AcquaNet - Dados de geração energia.

Os principais dados de entrada das demandas representadas e utilizadas nesta pesquisa (jusante, eclusa e dreno) para simulação da operação do reservatório são apresentados nas figuras a seguir.

A Figura 26 apresenta os dados de entrada da demanda de jusante. Como citado anteriormente, este valor $\left(330 \mathrm{~m}^{3} / \mathrm{s}\right)$ foi definido a partir de informações obtidas pela concessionária de energia CESP. 


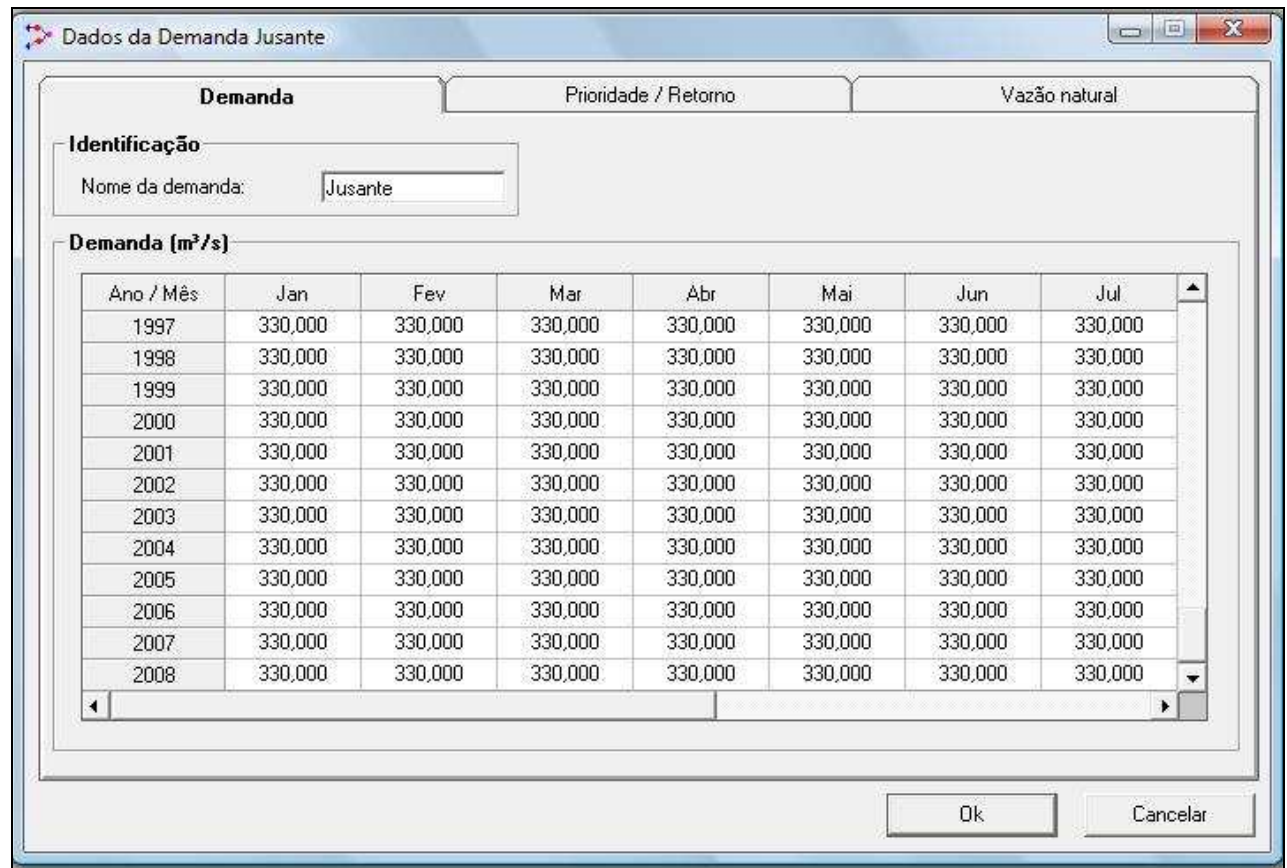

Figura 26. Janela de configuração do AcquaNet - Dados da demanda jusante.

Na Figura 27 são apresentados os dados de entrada da demanda de eclusa. Esta demanda representa a vazão utilizada no sistema de eclusagem do reservatório e teve seu valor definido $\left(0,3 \mathrm{~m}^{3} / \mathrm{s}\right)$ a partir de informações disponibilizadas pela CESP, referente à operação da eclusa no ano de 2009.

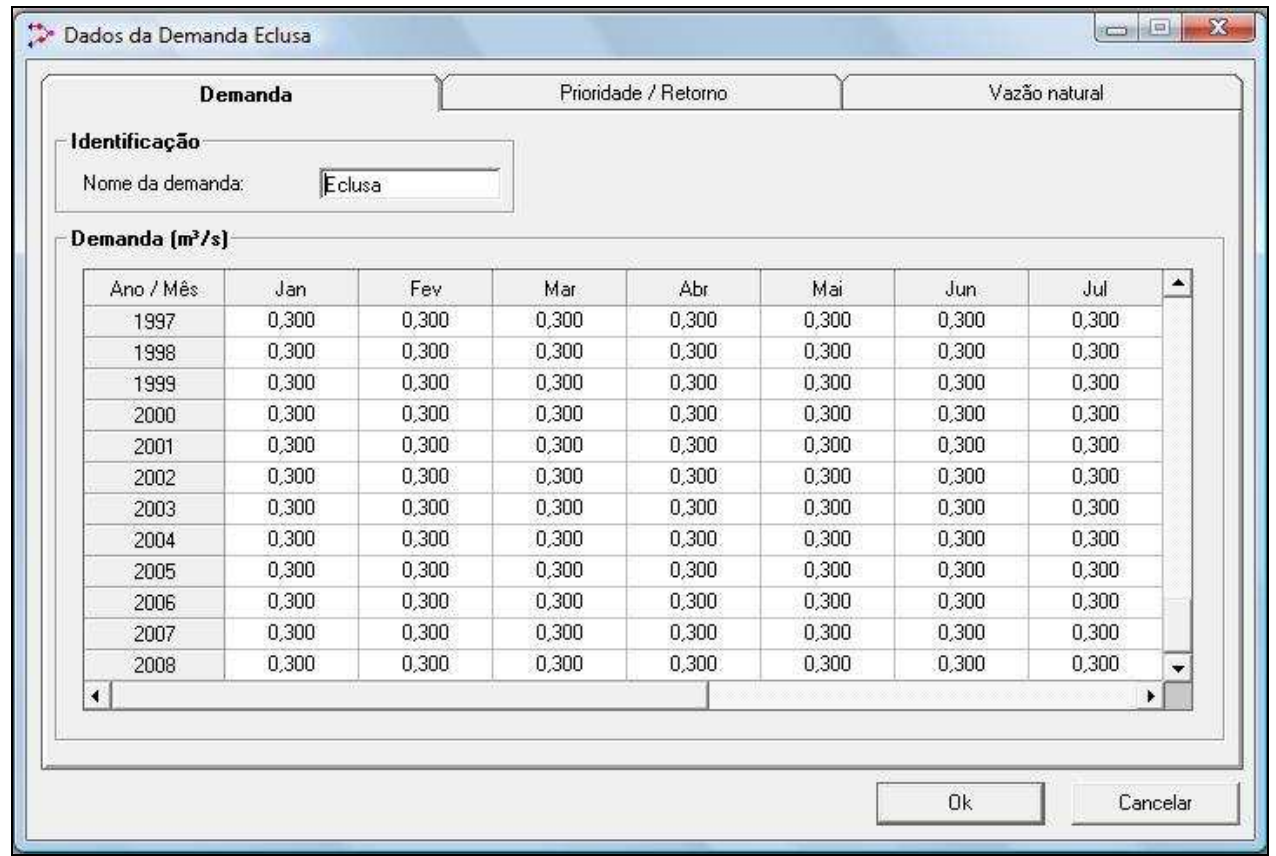

Figura 27. Janela de configuração do AcquaNet - Dados da demanda eclusa. 
Por fim, a Figura 28 apresenta os dados relativos à demanda fictícia de dreno cujo objetivo era receber todo o excesso de água que não foi utilizado e armazenado no reservatório, visando impedir o extravasamento do mesmo.

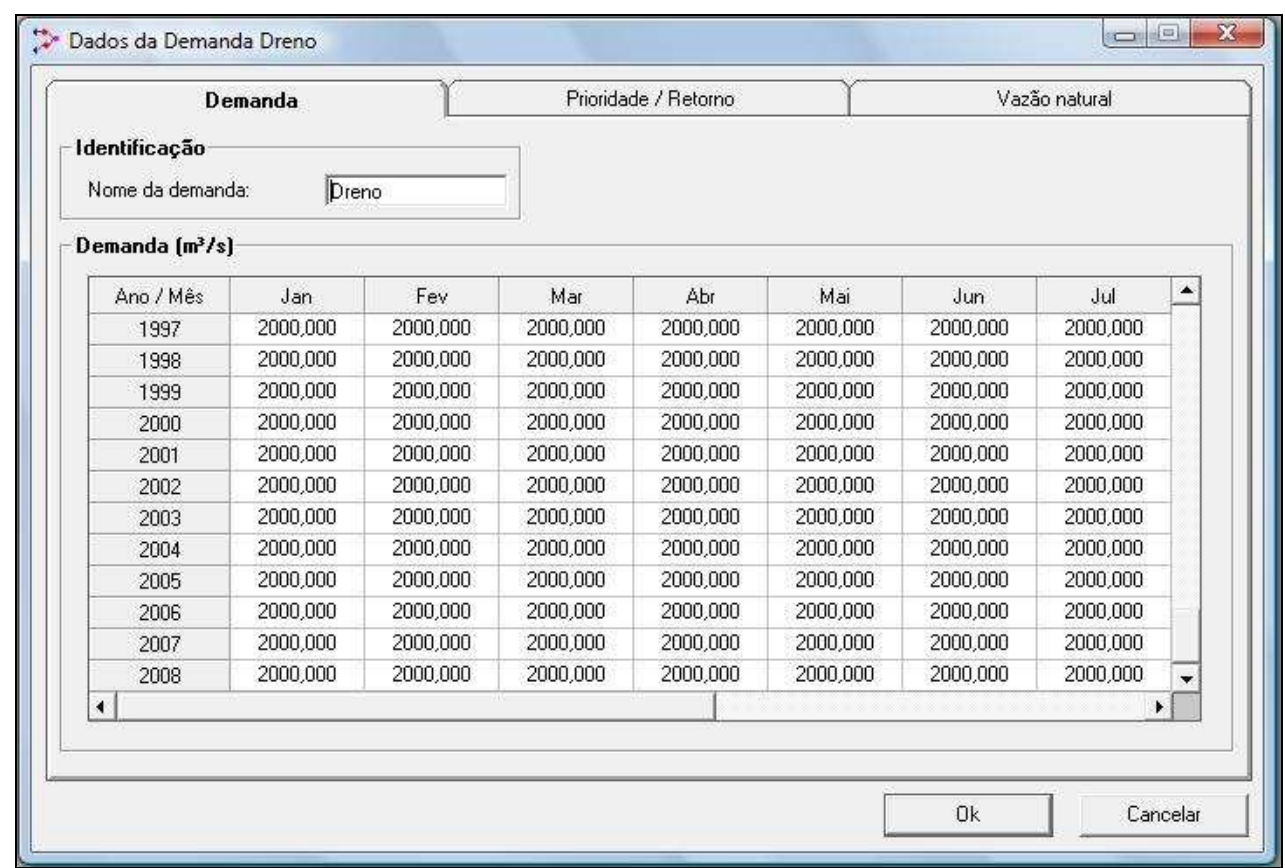

Figura 28. Janela de configuração do AcquaNet - Dados da demanda fictícia de dreno. 


\subsection{Influência do assoreamento na geração de energia elétrica}

A partir das simulações realizadas no software AcquaNet e descritas na seção anterior foi possível obter resultados relacionados ao atendimento das demandas hídricas do Reservatório de Três Irmãos, com destaque para a geração de energia elétrica.

A simulação do reservatório foi realizada a partir da rede apresentada anteriormente na Figura 18. Esta rede apresentava as principais demandas do reservatório como a geração de energia, a eclusagem e a vazão de jusante. As outras demandas do reservatório tiveram seus valores descontados na vazão afluente ao reservatório.

A partir da representação do reservatório e das suas principais demandas, foram realizadas as simulações da sua operação. Como citado anteriormente, estas análises corresponderam ao período de 1993 a 2008 e tiveram como base os dados fornecidos pela CESP e dados obtidos a partir de levantamentos batimétricos.

A simulação da operação do reservatório nesse período tinha como objetivo analisar a influência do assoreamento no atendimento das demandas do reservatório, uma vez que, este processo provoca redução na sua capacidade de armazenamento. Esta redução pôde ser verificada com a comparação dos dados fornecidos.

De acordo com os dados disponibilizados pela CESP (1975), o volume total do reservatório era de $13.371,21 \cdot 10^{6} \mathrm{~m}^{3}$, o volume útil era equivalente a $3.447,98 \cdot 10^{6} \mathrm{~m}^{3}$ e o volume morto apresentava cerca de $9.923,23 \cdot 10^{6} \mathrm{~m}^{3}$.

No entanto, segundo dados obtidos pelos levantamentos batimétricos (2008), os valores dos volumes total, útil e morto do reservatório tiveram uma significativa redução e eram equivalentes a $11.461,59 \cdot 10^{6} \mathrm{~m}^{3}, 2.947,07 \cdot 10^{6} \mathrm{~m}^{3}$ e $8.514,52 \cdot 10^{6} \mathrm{~m}^{3}$, respectivamente. 
Através da comparação entre os valores observados, pôde-se concluir que houve uma redução de $1.909,62 \cdot 10^{6} \mathrm{~m}^{3}$ no volume total do reservatório, $500,91 \cdot 10^{6} \mathrm{~m}^{3}$ no volume útil e $1.408,71 \cdot 10^{6} \mathrm{~m}^{3}$ no volume morto do reservatório, durante o período de 1975 a 2008.

Com relação aos valores percentuais, os volumes do reservatório foram reduzidos ao longo desses anos, em aproximadamente 14,3\% do volume total, $14,5 \%$ do volume útil e $14,2 \%$ do volume morto.

A Tabela 12 apresenta um resumo dos valores de volume do reservatório de acordo com os dados disponibilizados.

Tabela 12. Comparação entre os valores de volumes do reservatório.

\begin{tabular}{|c|c|c|c|c|}
\hline & $\begin{array}{c}\text { Dados CESP } \\
{\left[\mathbf{1 0}^{\mathbf{6}} \mathbf{~ m}^{\mathbf{3}}\right]}\end{array}$ & $\begin{array}{c}\text { Dados } \\
\text { Batimetria } \\
{\left[\mathbf{1 0}^{\mathbf{6}} \mathbf{~ m}^{\mathbf{3}}\right]}\end{array}$ & $\begin{array}{c}\text { Diferença } \\
{\left[\mathbf{1 0}^{\mathbf{6}} \mathbf{~ m}^{\mathbf{3}}\right]}\end{array}$ & $\begin{array}{c}\text { Diferença } \\
{[\%]}\end{array}$ \\
\hline Volume total & $13.371,21$ & $11.461,59$ & $1.909,62$ & 14,3 \\
\hline Volume útil & $3.447,98$ & $2.947,07$ & 500,91 & 14,5 \\
\hline Volume morto & $9.923,23$ & $8.514,52$ & $1.408,71$ & 14,2 \\
\hline
\end{tabular}

Fonte: FIPAI (2009).

A partir da Tabela 12, pode-se observar que (apesar destes números não representarem um valor absoluto, uma vez que a comparação realizada teve como base dados obtidos a partir de metodologias diferentes) houve uma redução significativa no volume do reservatório durante o período de 1975 a 2008, principalmente se levado em consideração a dimensão do reservatório. Assim, com a observação destas modificações nos volumes do reservatório, realizou-se a simulação de sua operação para verificar qual a influência destas alterações na geração de energia elétrica da usina.

Com os dados disponibilizados foi possível estabelecer a taxa de assoreamento registrado durante o período de 1975 a 2008, e assim estimar as condições do reservatório para o período de 1993 (início da operação da primeira turbina da UHE) a 2008, que foi o 
período determinado nesta pesquisa para o estudo da influência do assoreamento na geração de energia.

A partir dos dados estimados (cota $v s$. área $v s$. volume do reservatório) para o ano de 1993, foi realizado a simulação do reservatório no software AcquaNet considerando dois cenários diferentes.

No primeiro cenário foi considerado que o reservatório não foi assoreado no período de 1993 a 2008, ou seja, manteve-se os dados de entrada do reservatório constante para este período. Desse modo, observou-se uma potência total fornecida para o período simulado de aproximadamente 53.013 MW.

Para o segundo cenário foi considerado o assoreamento do reservatório no intervalo de 1993 a 2008. Com base na taxa de assoreamento do reservatório (encontrada a partir dos dados disponíveis) adotou-se o crescimento gradual e linear do assoreamento e determinaramse os novos dados de entrada (cota vs. área $v s$. volume) do reservatório para o período de 1993 a 2008. Neste caso, como citado, diferentemente da primeira simulação, considerou-se o assoreamento do reservatório neste período, ou seja, houve variação nos dados característicos de cota $v s$. área $v s$. volume do reservatório. A partir deste cenário, verificou-se uma potência total fornecida para o período analisado de aproximadamente 52.912 MW.

Deste modo, é possível observar que, assim como esperado, houve uma redução no valor da potência fornecida pela UHE em estudo, quando há a comparação entre as simulações do reservatório (considerando e desconsiderando o processo de assoreamento) de aproximadamente 101 MW para o período de 1993 a 2008.

Com os resultados obtidos (potência fornecida) nas simulações com o software AcquaNet, foi possível estimar a geração de energia para os dois cenários propostos. Verificou-se que para o primeiro cenário proposto (desconsiderando o processo de assoreamento) a energia gerada durante o período da simulação (1993 a 2008) foi de 
aproximadamente 38.169.056 MWh. Já para o segundo cenário (considerando o processo de assoreamento) a energia gerada foi cerca de 38.096.636 MWh. Neste caso, a redução de energia verificada, quando comparado os dois cenários, foi de $72.420 \mathrm{MWh}$ para o período e cenários analisados.

Outro resultado interessante que foi observado durante as simulações desses cenários, foi que as reduções energéticas constatadas, entre os períodos de um cenário e outro, foram todas nos meses de estiagem (considerado nesta pesquisa de maio a novembro). Esta observação comprova que o assoreamento tem suas consequências agravadas nos períodos de estiagem, devido aos sedimentos reduzirem o espaço destinado ao armazenamento da água essencial nestes períodos.

Esta constatação foi realizada após o tratamento dos resultados gerados pelo AcquaNet (com a seleção dos valores de potência fornecida nos meses de estiagem), onde pôde-se verificar que para o primeiro cenário (desconsiderando o processo de assoreamento) a energia total gerada durante os meses de estiagem foi cerca de 19.704.183 MWh (entre $1993 \mathrm{a}$ 2008). Já para o segundo cenário (considerando o assoreamento), o valor encontrado para a energia total gerada nos meses de estiagem foi de aproximadamente 19.631.763 MWh. Assim, pode-se observar que houve uma redução na energia total gerada, considerando apenas o período de estiagem, de aproximadamente $72.420 \mathrm{MWh}$, ou seja, toda a redução verificada no período de simulação.

Os principais resultados encontrados na simulação dos dois cenários propostos nessa pesquisa são apresentados na Tabela 13. 
Tabela 13. Comparação entre os principais resultados obtidos nas simulações do reservatório para o período de 1993 a 2008.

\begin{tabular}{|c|c|c|c|c|}
\hline Especificação & Cenário 1 & Cenário 2 & $\begin{array}{c}\text { Comparação } \\
\text { (Redução) }\end{array}$ & Unidade \\
\hline Potência total fornecida & 53.013 & 52.912 & 101 & $\mathrm{MW}$ \\
\hline Energia total gerada & 38.169 .056 & 38.096 .636 & 72.420 & $\mathrm{MWh}$ \\
\hline Energia média mensal gerada & 198.797 & 198.420 & 377 & $\mathrm{MWh}$ \\
\hline $\begin{array}{c}\text { Energia total gerada - período } \\
\text { de estiagem }\end{array}$ & 19.704 .183 & 19.631 .763 & 72.420 & $\mathrm{MWh}$ \\
\hline
\end{tabular}

Como é possível observar na Tabela 13, também foram obtidos os valores da energia média mensal gerada para cada cenário. Estes valores foram obtidos dividindo a energia total gerada em cada cenário pelo número de meses (192 meses) do período analisado (1993 a 2008).

A partir da redução da energia média mensal gerada (constatada entre os dois cenários) pôde-se verificar que esta perda energética (377 MWh/mês) poderia suprir o atendimento de aproximadamente 1.508 residências que apresentassem um consumo mensal de $250 \mathrm{kWh}$.

Com os resultados obtidos a partir das simulações da operação do reservatório e da UHE de Três Irmãos, também foi possível estimar quais seriam as perdas financeiras ocasionadas pelo assoreamento do reservatório de acordo com a metodologia adotada nesta pesquisa.

Como os valores de comercialização da energia gerada na usina variam de acordo com o período e a disponibilidade energética do momento, entre outros fatores, no caso deste estudo, foram adotados três valores para estimar as perdas financeiras decorrentes da redução energética verificada: R \$ 50,00/MWh; R \$ 100,00/MWh e R \$ 150,00/MWh. 
Cabe destacar que esses preços não são valores fixos ou pré-definidos pela CESP. Porém, estes valores abrangem as faixas de preços utilizados pela concessionária de energia para comercialização da sua energia gerada em diferentes épocas e situações.

As prováveis perdas financeiras ocasionadas a partir dos resultados obtidos nas simulações deste trabalho são apresentadas na Tabela 14. Estes valores foram calculados com base na comparação da energia média mensal gerada (apresentada anteriormente na Tabela 13).

Tabela 14. Estimativa das perdas médias mensais energética e financeira entre os dois cenários propostos.

\begin{tabular}{|c|c|c|c|}
\hline \multirow{2}{*}{$\begin{array}{c}\text { Perda média } \\
\text { mensal energética }\end{array}$} & \multicolumn{3}{|c|}{ Perda média mensal financeira } \\
\cline { 2 - 4 } & $\mathbf{R} \$ \mathbf{5 0 , 0 0 / M W h}$ & $\mathbf{R} \$ \mathbf{1 0 0 , 0 0 / M W h}$ & $\mathbf{R} \mathbf{1 5 0 , 0 0 / M W h}$ \\
\hline $377 \mathrm{MWh}$ & $\mathrm{R} \$ 18.850,00$ & $\mathrm{R} \$ 37.700,00$ & $\mathrm{R} \$ 56.550,00$ \\
\hline
\end{tabular}

A partir dos valores apresentados na Tabela 14, pode-se observar que há uma perda no faturamento mensal da empresa de energia quando comparado os cenários propostos nesta pesquisa.

Apesar de não representar um valor absoluto, e sim uma estimativa das possíveis perdas financeiras (uma vez que estes valores foram calculados a partir de dados obtidos nas simulações da operação do reservatório e com valores estimados para comercialização da energia) estes valores demonstram que o assoreamento do reservatório merece receber uma atenção especial.

Outro fato que deve ser destacado é que os valores obtidos na Tabela 14 não fazem distinção dos preços da energia firme e excedente que é comercializada pela concessionária de energia. A diferenciação da energia não foi realizada nesta pesquisa porque a concessionária apresenta a energia firme da Usina de Três Irmãos junto com a Usina de Ilha Solteira. Por este motivo, não foi possível estimar com mais precisão qual é a real perda financeira que a empresa tem com a redução da produção energética. 


\subsection{Medidas preventivas e corretivas para o controle do assoreamento no local de estudo}

Como citado no decorrer deste estudo, apesar do assoreamento ser um processo inevitável, é possível minimizar e/ou evitar grande parte dos problemas causados pelos sedimentos nos cursos d'água a partir da adoção de medidas preventivas e corretivas.

A escolha da melhor política de controle do assoreamento exige estudos específicos sobre a dinâmica dos sedimentos desde as suas áreas fontes até os seus locais de deposição.

No caso do local de estudo deste trabalho (Reservatório de Três Irmãos), pôde-se observar que os principais fatores que influenciam na deposição de sedimento no reservatório, devem-se aos processos erosivos do seu entorno.

Esse fato pode ser justificado, pois o Reservatório de Três Irmãos apresenta em suas margens grandes áreas com cultivo de cana-de-açúcar (Figura 29) e presença de pastagens e gado (Figura 30). A prática destas ações próximas ao reservatório ressalta a importância de estudos sedimentológicos neste corpo hídrico, pois estas atividades intensificam os processos erosivos na bacia hidrográfica e consequente geração e depósito de sedimentos no reservatório. 


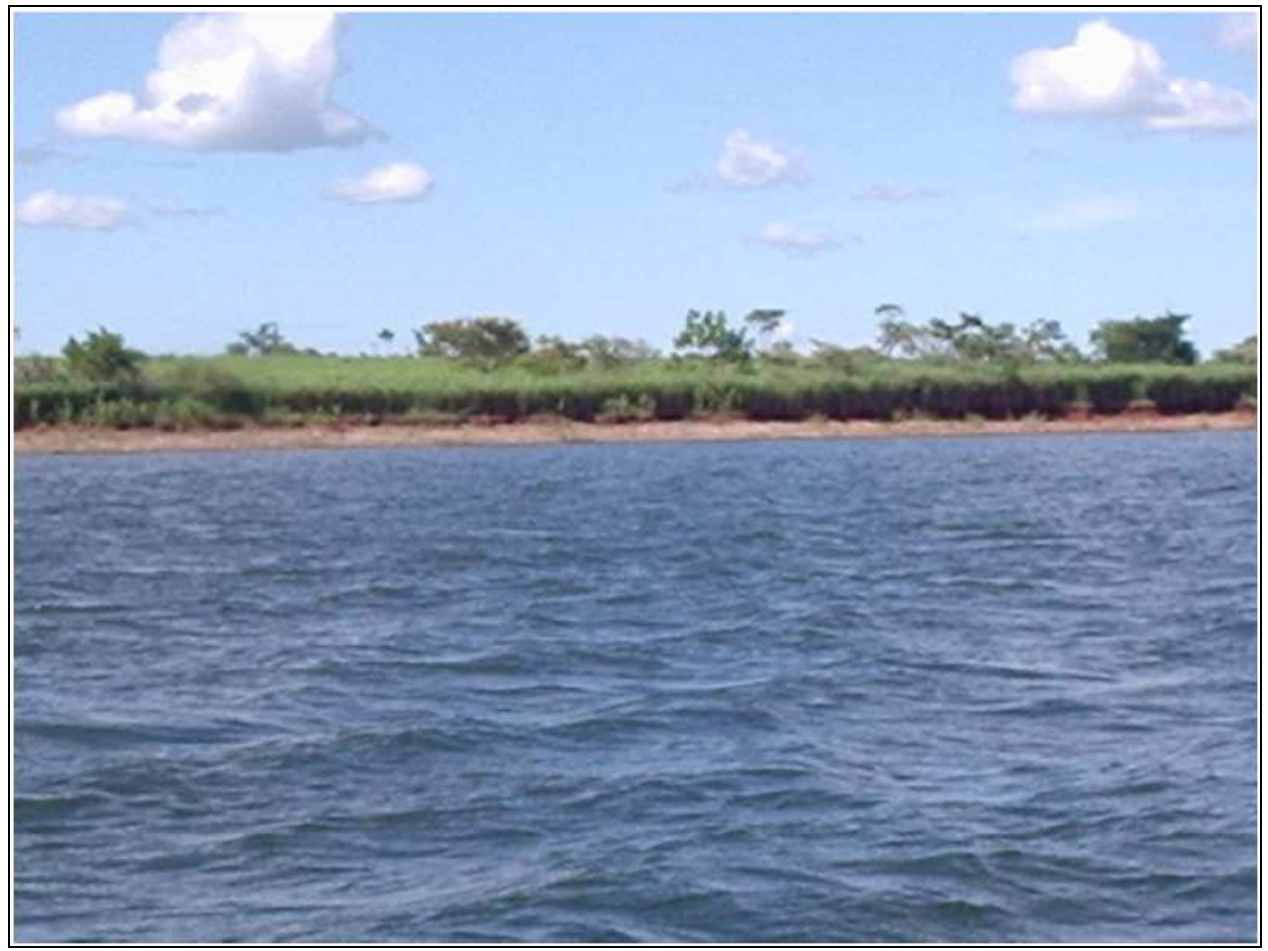

Figura 29. Cultivo de cana-de-açúcar próximo às margens do Reservatório de Três Irmãos. Fonte: FIPAI (2009).

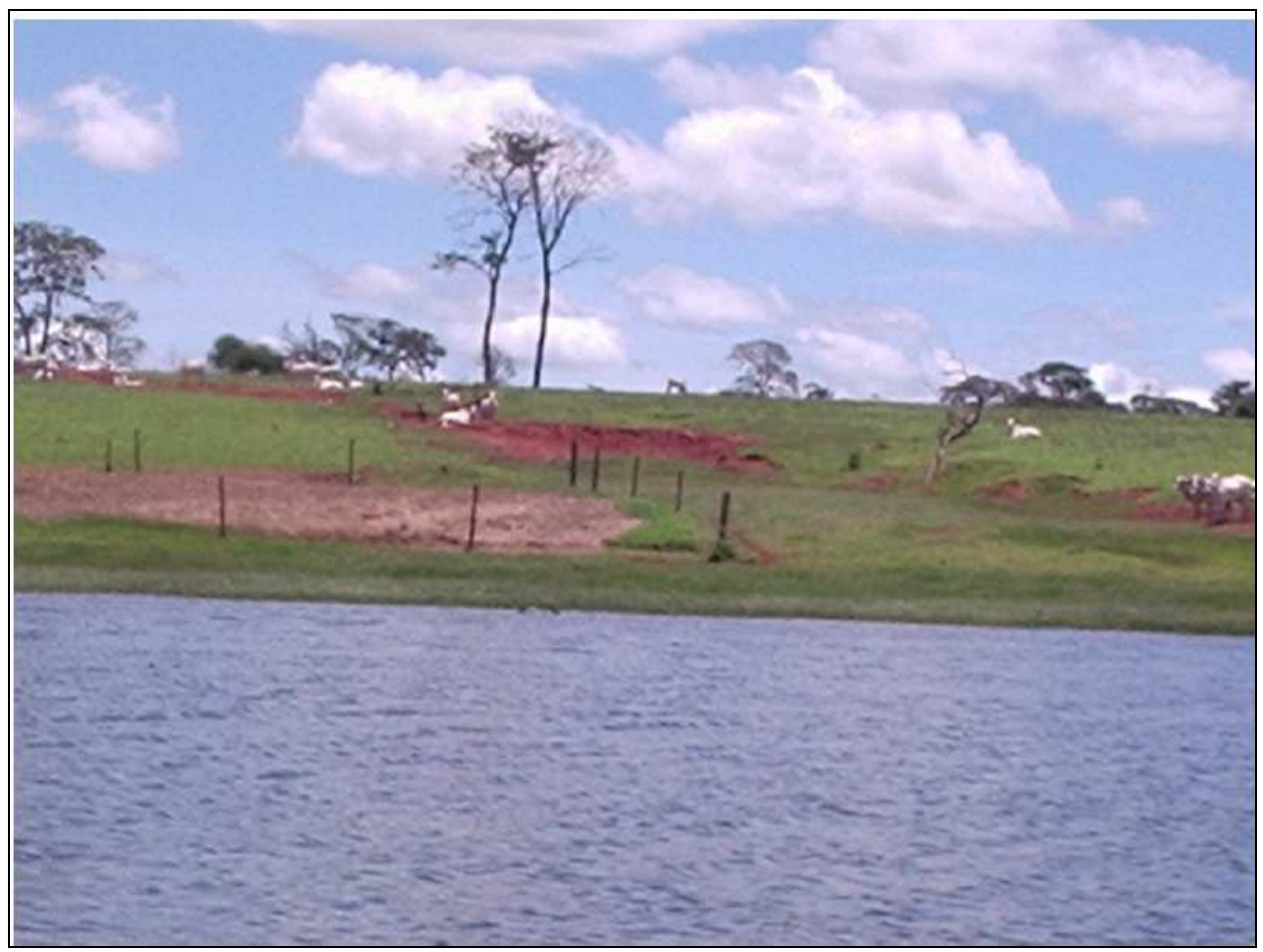

Figura 30. Presença de pastagem e gado nas margens do Reservatório de Três Irmãos. Fonte: FIPAI (2009). 
No caso do reservatório em questão, verifica-se que a presença de atividades pecuárias propicia problemas de erosão nas áreas próximas ao reservatório, principalmente devido à criação de caminhos gerados pelo pisoteamento do gado.

As atividades agrícolas no entorno do reservatório são muito prejudiciais, principalmente nos intervalos entre um plantio e outro. Isto ocorre porque no intervalo entre a colheita e a plantação de novas safras o solo fica desnudo intensificando a produção e o transporte dos sedimentos principalmente em períodos chuvosos. Este fato ocorre no Reservatório de Três Irmãos e pode ser observado pela Figura 31, que apresenta áreas próximas às margens do reservatório com solos expostos devido aos períodos de colheita e plantação de novas safras de cana-de-açúcar.

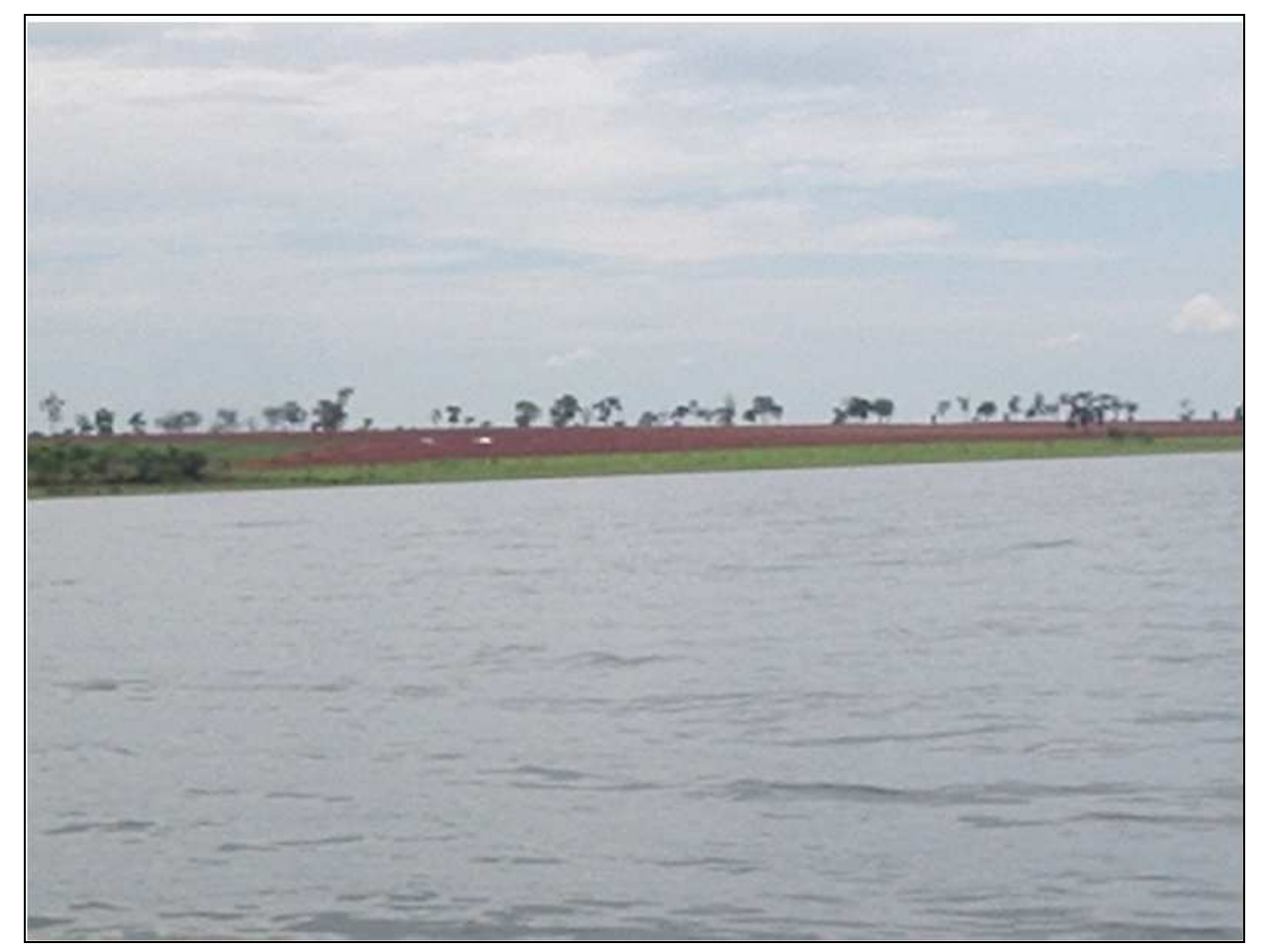

Figura 31. Área com solo exposto próxima à margem do reservatório na época do plantio da cana-deaçúcar.

Fonte: FIPAI (2009). 
O transporte dos sedimentos para os corpos d'água, além de causar o assoreamento do reservatório também interfere nas atividades agrícolas, pois os materiais carreados pelas chuvas ou vento contêm nutrientes que são retirados do solo e tornam os mesmos mais pobres para o plantio.

A presença de nutrientes (sais, metais e outros compostos nitrogenados), além de causar degradação da qualidade da água, também pode causar eutrofização ${ }^{31}$ do meio aquático, acarretando no aumento do crescimento de algas e macrófitas que provocam grandes problemas para as turbinas das usinas hidrelétricas.

A partir da observação destas atividades próximas ao reservatório, conclui-se que a principal ação preventiva que poderia ser adotada para a redução da taxa de assoreamento do reservatório em estudo, seria o controle das fontes de produção de sedimentos da bacia hidrográfica, uma vez que a deposição dos sedimentos é a última fase de um processo que se inicia na erosão da bacia.

Conforme citado na seção 3.3, por Carvalho (2008), Paiva et al. (2001) e Muller (1995), entre outros, as medidas preventivas são mais eficazes do que as medidas corretivas (tanto em questões técnicas quanto financeiras) e deveriam ser adotadas com mais frequência para minimizar os problemas de deposição de sedimento.

Neste sentido, o plantio e a conservação de matas ciliares nas margens do reservatório se destacam como uma das principais ações preventivas que poderiam ser adotada para reduzir a produção de sedimentos no Reservatório de Três Irmãos. Desse modo, seria recomendado que houvesse um reforço nas políticas de produção de mudas de árvores e dos programas de reflorestamento do reservatório.

\footnotetext{
31 “A eutrofização é causada por processos de erosão e decomposição que fazem aumentar o conteúdo de nutrientes, aumentando a produtividade biológica, permitindo periódicas proliferações de algas, que tornam a água turva e com isso podem causar deficiência de oxigênio pelo seu apodrecimento, aumentando sua toxidez para os organismos que nela vivem." Fonte: http://educar.sc.usp.br/biologia/textos/m_a_txt5.html.
} 
Outra ação que poderia ser adotada na região do reservatório seria a intensificação de palestras e cursos voltados à comunidade local sobre educação ambiental e práticas conservacionistas do solo.

Essas ações possibilitariam uma maior conscientização e instrução da população local, uma vez que a implantação de medidas preventivas contra o assoreamento é dificultada pelo fato dos resultados originados pelas melhorias serem obtidos a médio e longo prazo. Este fato é comprovado em grande parte dos programas de reflorestamento propostos pelas concessionárias de energia, que muitas vezes não são bem sucedidos devido à baixa adesão da população e dos proprietários locais, algumas vezes por ignorância de não conhecer direto os problemas do assoreamento e outras por própria conivência.

Outro fato que merece ser destacado é a necessidade de políticas públicas mais eficientes para inspeção e penalização de proprietários de terras, próximas às margens dos cursos d'água, que não atendam às normas vigentes, principalmente quanto à conservação de matas ciliares.

Além das medidas preventivas, citadas anteriormente, também poderiam ser adotadas outras ações para que os sedimentos gerados não alcancem o reservatório, como a instalação de pequenas barragens a montante, bacias de decantação e condutos de desvio de sedimentos, entre outros, casos não existam.

No âmbito das medidas corretivas para o controle do assoreamento e a minimização dos seus efeitos no reservatório, poderiam ser adotadas ações para remoção dos sedimentos em alguns trechos do mesmo.

A escolha e a quantidade de material sólido que poderiam ser retiradas do reservatório dependem de estudos técnicos e econômicos para a obtenção da melhor relação entre as eventuais melhorias que seriam propiciadas pela remoção dos sedimentos e seus eventuais custos (questão custo-benefício). 
Nesse sentido, os levantamentos batimétricos possibilitam a localização dos trechos mais comprometidos ou que apresentem resultados mais interessantes para remoção dos sedimentos.

Um dos estudos realizados no reservatório em questão é o Projeto de Pesquisa e Desenvolvimento "Estudos do assoreamento do reservatório formado pela barragem da UHE Três Irmãos" (FIPAI, 2009), que apresenta como um dos seus principais resultados as áreas com maior incidência de depósitos de sedimentos no Reservatório de Três Irmãos, como demonstrado na Figura 32.

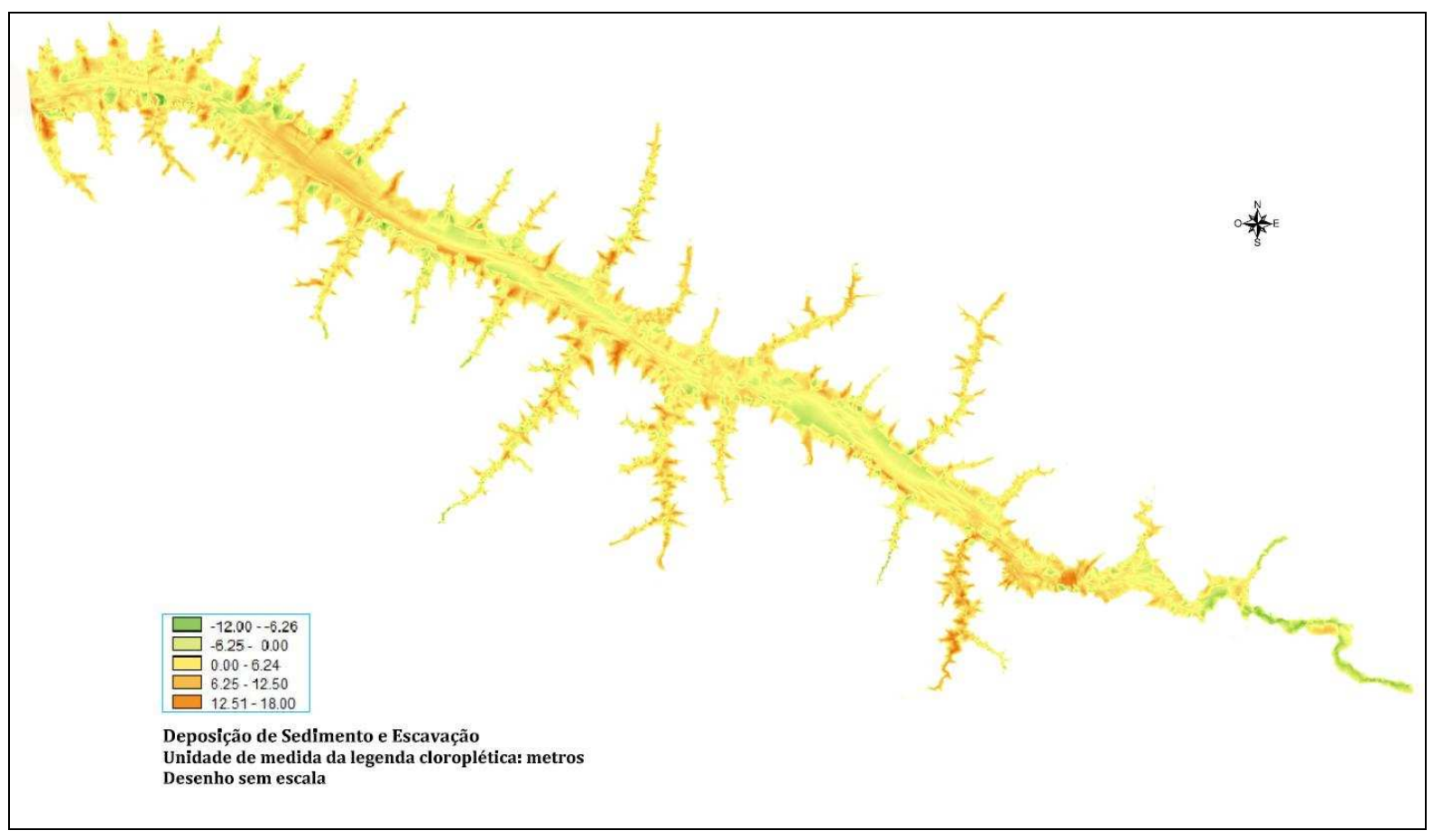

Figura 32. Localização dos depósitos de sedimentos e escavações no Reservatório de Três Irmãos. Fonte: FIPAI (2009).

A dragagem dos sedimentos, além de possibilitar um aumento na capacidade de armazenamento do reservatório, também seria uma alternativa interessante para remoção dos sedimentos que comprometem ou poderão comprometer futuramente as estruturas hidráulicas da usina e afetar a segurança do reservatório. 
Apesar desta técnica apresentar algumas desvantagens, conforme visto anteriormente na seção 3.3, esta tecnologia apresenta como vantagem, a possível utilização dos materiais dragados no reservatório para o uso em obras da construção civil. Desse modo, parte dos materiais dragados (como areia e argila) poderia ser tratada e comercializada e ter seus ganhos utilizados para redução dos custos totais do processo de dragagem.

Nesse sentido, o assoreamento do Reservatório de Três Irmãos e os seus eventuais problemas poderiam ser reduzidos por meio de duas medidas básicas: a intensificação das políticas de controle dos processos erosivos da bacia hidrográfica onde se encontra o reservatório e a remoção de parte dos sedimentos já depositados no reservatório, a partir da dragagem e a possível comercialização de parte dos materiais retirados.

Com estas medidas, entende-se que o reservatório em estudo poderia ter um melhor aproveitamento no atendimento das demandas hídricas e na produção energética. 


\section{CONCLUSÕES E RECOMENDAÇÕES}

Através deste estudo, foi possível verificar os problemas e as perdas energéticas ocasionadas pelo assoreamento de reservatórios hidrelétricos e constatar que os estudos sedimentológicos e os levantamentos batimétricos são de extrema importância para o planejamento e o gerenciamento hídrico e energético, principalmente em países como o Brasil, que apresentam uma matriz energética baseada em fontes hidráulicas.

Como descrito no decorrer do trabalho, os estudos sedimentológicos são importantes, porque os sedimentos transportados pelos cursos d'água e acumulados em reservatório causam inúmeros problemas como: redução da capacidade de armazenamento dos reservatórios; obstrução de canais de irrigação; criação de bancos de sedimentos que dificultam a navegação; alteração, destruição e degradação de ecossistemas aquáticos; problemas na operação e manobra de eclusas e comportas de usinas hidrelétricas; degradação da qualidade da água para consumo; veiculação de poluentes; entre outros.

Os levantamentos batimétricos, por sua vez, possibilitam a determinação das reais dimensões e condições dos reservatórios, com a atualização dos seus dados de cota vs. área vs. volume. Assim, pode-se ter uma avaliação mais precisa nos gerenciamentos e operações dos reservatórios que, muitas vezes, são baseadas em dados defasados ou fundamentados em informações de projeto.

Esses fatos foram comprovados neste estudo com a apresentação dos dados obtidos no levantamento batimétrico realizado no Reservatório de Três Irmãos (em 2008), onde se pôde constatar que houve uma significativa alteração nos dados operacionais do reservatório quando comparado aos dados utilizados atualmente pela concessionária de energia que o administra. Através dos dados obtidos na batimetria, verificou-se uma redução de 
$1.909,62 \cdot 10^{6} \mathrm{~m}^{3}(14,3 \%)$ no volume total do reservatório, 500,91·10 $\mathrm{m}^{3}(14,5 \%)$ no volume útil e $1.408,71 \cdot 10^{6} \mathrm{~m}^{3}(14,2 \%)$ no volume morto do reservatório.

As modificações observadas no reservatório motivaram esta pesquisa na intenção de verificar a influência destas alterações na geração de energia da usina que utiliza este reservatório.

Para realizar essa análise, foi utilizado o software AcquaNet, o qual é baseado nos modelos de rede de fluxo, e se mostrou uma ferramenta muito interessante para simulação de sistemas de recursos hídricos, principalmente quanto às questões de planejamento e gerenciamento de reservatórios hidrelétricos.

Um dos principais motivos para escolha deste software, deve-se ao fato do mesmo utilizar, simultaneamente, modelos de simulação e otimização, com a intenção de restringir as limitações e utilizar as principais vantagens de cada técnica. Outro fato que justifica a escolha do software foi a quantidade e a diversidade de estudos que utilizaram o mesmo.

Os resultados obtidos, a partir da metodologia adotada nesta pesquisa, indicam a possibilidade de existirem perdas na geração de energia elétrica da usina estudada, devido ao assoreamento do reservatório. Estas perdas energéticas, consequentemente acarretam em perdas financeiras para a concessionária de energia.

Como forma de evitar ou minimizar estas perdas e alguns problemas causados pelo assoreamento, foram propostas neste estudo, algumas medidas preventivas e corretivas para o controle do assoreamento no reservatório em estudo. Foi sugerida a intensificação de políticas de controle dos processos erosivos do local e a retirada de parte dos sedimentos depositados no reservatório, com a possível comercialização de parte dos materiais retirados, como forma de reduzir os custos deste processo.

Além disto, também foi ressaltada a importância de ações para a conscientização da população e dos proprietários de terras no entorno do reservatório para aumentar a 
participação deles em programas voltados à conservação dos recursos hídricos, como o reflorestamento das margens de reservatórios. Outro fato destacado é a implantação de políticas públicas mais eficientes para fiscalização e penalização de proprietários que não atendam às normas vigentes, principalmente quanto à conservação de matas ciliares nas margens dos cursos d'água.

Cabe destacar que, muitas vezes, os custos com as perdas energéticas e manutenção dos equipamentos danificados pelos sedimentos, demonstram que investimentos para conter a geração, o transporte e a deposição dos sedimentos são recuperáveis em um curto prazo de tempo.

Assim, entende-se que os estudos sedimentológicos devem receber a mesma atenção depreendida aos estudos hidrológicos, ou seja, do mesmo modo que há instalação, operação e manutenção das estações fluviométricas, isto deve ocorrer também com as estações sedimentométricas.

De um modo geral, a intenção desta pesquisa foi apresentar, discutir e incentivar estudos nesta área de conhecimento, pois através destes estudos, pode-se estabelecer melhores políticas de gestão dos recursos hídricos e energéticos que demandam um conhecimento multidisciplinar e envolvem aspectos econômicos, sociais, ambientais, entre outros.

Além dos fatos apresentados, cabe destacar que a conservação dos reservatórios e das usinas hidrelétricas que estão em operação atualmente é muito importante, pois está cada vez mais difícil encontrar locais para construção de novas barragens, uma vez que muitos locais já foram explorados. Do mesmo modo, a melhora energética decorrente dos estudos apresentados, podem ser utilizada como complemento à construção de novas usinas, tendo em vista as questões financeiras, ambientais e sociais que envolvem a construção de novos empreendimentos deste tipo. 
Como recomendações para trabalhos futuros que possam complementar esse estudo sugere-se:

- Realizar novos levantamentos batimétricos no Reservatório de Três Irmãos para acompanhar a evolução do assoreamento e verificar as modificações ocasionadas nos dados operacionais do reservatório e a influência destas modificações na geração de energia;

- Realizar estudos semelhantes a este em outros reservatórios e usinas hidrelétricas, e utilizar o AcquaNet ou outros softwares para comparar com os resultados obtidos nesta pesquisa;

- Desenvolver pesquisas semelhantes a esta tendo como foco a análise de outras demandas (como o abastecimento urbano, a agricultura ou a vazão de jusante) e utilizar os outros módulos do software AcquaNet;

- Estudar mais detalhadamente a questão das perdas financeiras ocasionadas pelo assoreamento de reservatório, utilizando softwares adotados pelos órgãos do sistema elétrico brasileiro para a análise. 


\section{REFERÊNCIAS BIBLIOGRÁFICAS}

AGÊNCIA NACIONAL DE ÁGUAS - ANA. (2010). Programa de monitoramento dos resultados das ações do programa produtor de água. Disponível em: < http://www.ana.gov.br/Produagua/LinkClick.aspx?fileticket=1Thji8meZcc\%3D\&tabid=708\& mid=1516>. Acesso em: 15 out. 2010.

AGÊNCIA NACIONAL DE ÁGUAS - ANA. (2009). Manual de Estudos de Disponibilidade Hídrica para Aproveitamentos Hidrelétricos. Manual do Usuário. 43 p.

ALBANO, G.D. (2004). Integração de um modelo matemático de quantidade de água em rede de fluxo (ACQUANET) com um modelo matemático de qualidade de água em represas (CE-QUAL-R1) - Estudo de Caso: Represa Jaguari-Jacareí - Sistema Cantareira. Dissertação (Mestrado em Engenharia Civil). Escola Politécnica, Universidade de São Paulo, São Paulo. 230 p.

ALMEIDA, S.B; CARVALHO, N.O. (1993). Efeitos do assoreamento de reservatórios na geração de energia elétrica: Análise da UHE Mascarenhas, ES. In: X Simpósio Brasileiro de Recursos Hídrico, Gramado, RS, p. 167-173.

ASTHANA, B.N.; NIGAM, P.S. (1980). Distribution of Sediment in Reservoirs. Journal of the Institute of Engineers (India), v. 60.

AZEVEDO, L.G.T.; PORTO, R.L.; ZAHED FILHO, K. (1997). Modelos de Simulação e de Rede de Fluxo. In: PORTO, R.L. (Org). Técnicas quantitativas para gerenciamento de recursos hídricos. Porto Alegre: UFRGS/ABRH. Cap. 4, p. 165-227.

BARROS, M.T.L. (2010). Notas de Aulas. Disponível em: <http://www.fcth.br/public/cursos/phd5029/aulasistemas.PDF>. Acesso em: 20 nov. 2010.

BARROSO, D.G.; SILVA, M.L.N. (1992). Poluição e conservação dos recursos naturais: solo e água. Informe agropecuário, v.176, n.16, p. 17-24. 
BAZARAA, M.S.; JARVIS, J.J.; SHERALI, H.D. (1977). Linear Programming and Network Flows, 2.ed., John Wiley \& Sons.

BERMANN, C. (2007). Impasses e controvérsias da hidroeletricidade. Estudos Avançados, v. 21, p. 139-153.

BHUYAN, S.J.; KALITA, P.K.; JANSSEN, K.A.; BARNES, P.L. (2002). Soil loss predictions with three erosion simulation models. Environmental Modeling \& Software, 17, p. 137-146.

BRANCO, S.M.; ROCHA, A.A. (1977). Poluição, Proteção e Usos Múltiplos de Represas. São Paulo. Edgard Blucher. CETESB.

BRANCO, N.; PAIVA, J.B.D.; PAIVA, E.M.C.D. (1998). Produção de sedimentos da bacia hidrográfica do Arroio Vacacaí Mirim - Avaliação Preliminar. In: XVII Congreso Nacional del Água, II Simpósio de Recursos Hídricos Del Conosur, Santa Fé: BRH Digital, v.3. p. 444-451.

BRASIL (2010). Agência Nacional de Energia Elétrica e Agência Nacional de Águas. Resolução Conjunta $\mathbf{n}^{\mathbf{0}} \mathbf{3}-10$ de agosto de 2010. Disponível em: <http://www.aneel.gov.br/cedoc/res2010003cj.pdf>. Acesso em: 08 set. 2010.

BRASIL (2004). Conselho Nacional do Meio Ambiente - CONAMA. Resolução CONAMA, no 344 - 25 de março de 2004. Diário Oficial da União. Disponível em: <http://www.mma.gov.br/port/conama/res/res04/res34404.xml>. Acesso em: 05 set. 2010.

BRASIL. (1984). Ministério das Minas e Energia. Departamento Nacional de Águas e Energia Elétrica. Curso sobre estudo do transporte sólido nos cursos d'água e assoreamento de reservatórios de uso múltiplo. São Paulo. Ilha Solteira, v. 2.

BRASIL. (1965). Lei $\mathbf{n}^{0}$ 4.771, de 15 de setembro de 1965. Institui o novo Código Florestal. Disponível em: < http://www.aneel.gov.br/cedoc/blei19654771.pdf >. Acesso em: 20 out. 2010. 
BRUNE, G.M; ALLEN, R.E. (1941). A consideration of factor influencing reservoir sedimentation. In: The Ohio Valley Region. American Geophysical Union. v.2.

BUFON, A.G.M. (2006). Estudo do assoreamento e sua relação com a vida útil do Reservatório "Represa Velha", CEPTA/IBAMA, Pirassununga/SP. Tese (Doutorado em Geociências). Instituto de Geociências e Ciências Exatas, Universidade Estadual Paulista, Rio Claro, 313 p.

CABRAL, J.B.P. (2005). Estudo do Processo de Assoreamento em Reservatórios. Caminhos de Geografia (6). v. 14. p. 62-69.

CAMPOS, J.C.; LANDGRAF, P.R.C. (2001). Análise da Regeneração Natural de Espécies Florestais em Matas Ciliares de Acordo com a Distância da Margem do Lago. Ciência Florestal, Santa Maria, v. 11, n.2, p. 143-151.

CARLSTRON FILHO, C.; GIMENEZ, A.F.; PIRES NETO, A.G.; PRADINI, L.F.; MELO, M.S.; FUlFARO, V.J.; PONÇANO, W.L. (1981). Metodologia para Estudo de Assoreamento de Reservatórios (II) Reservatório de Passo Real e Ernestina (RS). In: CBGE, 3, Itapema (SC), Anais. São Paulo. ABGE. p. 143-162.

CARVALHO, N.O. (2000). Assoreamento de reservatórios - consequiências e mitigação dos efeitos. In: Encontro Nacional de engenharia de Sedimentos, Santa Maria. Cd rom. 1.

CARVALHO, N.O. (2008). Hidrossedimentologia Prática. Rio de Janeiro: Interciência. 599 p.

CARVALHO, N.O.; CATHARINO, M.G. (1993). Avaliação do reservatório da UHE Itaipu, PR. In: Simpósio Brasileiro de Recursos Hídricos, 10.; Simpósio de Recursos Hídricos do Cone Sul, 1., São Paulo: Associação Brasileira dos Recursos Hídricos. p. 174183.

CARVALHO, N.O; LÔU, W.C. (1986). Avaliação da vida útil do reservatório da barragem no Rio Manso no Estado do Mato Grosso. Revista Brasileira de Engenharia, Caderno de Grandes Barragens, 1 (2), p. 61-70. 
CARVALHO, N.O.; FILIZOLA JÚNIOR, N.P.; SANTOS, P.M.C.; LIMA, J.E.F.W. (2000a). Guia de práticas sedimentométricas. Brasília: ANEEL. 95 p.

CARVALHO, N.O.; FILIZOLA JÚNIOR, N.P.; SANTOS, P.M.C.; LIMA, J.E.F.W. (2000b). Guia de avaliação de assoreamento de reservatórios. Brasília: ANEEL. 107 p.

CARVAlHO, M.A.; MÉllO JÚNIOR, A.V.; SCHARDONG, A.; PORTO, R.L. (2009). Sistema de suporte à decisão para alocação de água em projetos de irrigação. Revista Brasileira de Engenharia Agrícola e Ambiental, v.13, n.1, p.10-17.

CENTRO TECNOLÓGICO DA FUNDAÇÃO PAULISTA DE TECNOLOGIA E EDUCAÇÃO - CETEC. (2008). Plano de Bacia do Baixo Tietê 2008 - Relatório Final. 282 p.

CENTRO TECNOLÓGICO DA FUNDAÇÃO PAULISTA DE TECNOLOGIA E EDUCAÇÃO - CETEC. (1999). Situação dos Recursos Hídricos do Baixo Tietê - UGRHI 19. Minuta Preliminar do Relatório Técnico Final. Lins, São Paulo, 261 p.

CHANSON, H; JAMES, P. (1998). Rapid reservoir sedimentation of four historic thin arch dams in Australia. J. Perform. Constr. Facil, ASCE, 12(3). p. 85-92.

COELHO, M.P. (1993). Análise do processo de assoreamento do reservatório de Americana - SP. Dissertação de Mestrado em Geociências. Universidade Estadual Paulista. $69 \mathrm{p}$.

COIADO, E.M. (2001). Assoreamento de Reservatórios. In: PAIVA J.B.D; PAIVA E.M.C.D (Orgs.). Hidrologia Aplicada à Gestão de Pequenas Bacias Hidrográficas. Porto Alegre: ABRH. p. 395-426.

COMPANHIA ENERGÉTICA DE SÃO PAULO - CESP. (2010). UHE Três Irmãos. Disponível em: <http://www.cesp.com.br>. Acesso em: 03 set. 2010.

CORRÊA FILHO, C.R.R.; ALBERTIN, L.L.; MAUAD, F.F.; SIMIONATO, J.L.A.; MANGILE, F. (2005). Levantamento Batimétrico de um Grande Reservatório Formado 
por Barragem Utilizando a Sonda Acoustic Doppler Profiler - ADP. In: XVI Simpósio Brasileiro de Recursos Hídricos, João Pessoa. Integrando a Gestão de Águas às Políticas Sociais e de Desenvolvimento Econômico. ABRH, 2005. vol. 1. p. 1-19.

DILL, P.R.J. (2002). Avaliação do Assoreamento do Reservatório do Vacacaí-Mirim e sua relação com a deterioração da Microbacia Hidrográfica Contribuinte, RS. Dissertação (Mestrado em Recursos Hídricos e Saneamento Ambiental). Universidade Federal de Santa Maria, Santa Maria, 112 p.

ENVIRONMENTAL PROTECTION AGENCY - EPA. (1976). Erosion and sediment control. Washington: Surface Mining in the Eastern US. v.1.

FUNDAÇÃO PARA O INCREMENTO DA PESQUISA E DO APERFEIÇOAMENTO INDUSTRIAL - FIPAI. (2009). Estudo do Assoreamento do Reservatório Formado pela Barragem da UHE Três Irmãos. Relatório P\&D. Convênio FIPAI/CESP. São Carlos. 197 p.

FUNDAÇÃO SISTEMA ESTADUAL DE ANÁLISE DE DADOS - SEADE. (2007). População e estatísticas vitais. Disponível em: 〈http//www.seade.sp.gov.br〉.

GIMENEZ, A.F; CARLSTRON FILHO, C.; CARNEIRO, C.D.R; STEIN, D.P.; PRADINI, L.F.; MELO, M.S.; FULFARO, V.J.; PONÇANO, W.L. (1981). Metodologia de Estudo de Assoreamento de Reservatórios (I) Reservatório de Capivari (PR). In: CBGE, 3, Itapema (SC), Anais. São Paulo. ABGE. p. 205-224.

GLYMPH, L.M. (1973). Sedimentation of Reservoirs. In: ACKERMANN, W.C. et al., ed. Man-made lakes: their problems and environmental. Washington DC: American Geophysical Union. p. 342-346.

GOLDSMITH, E.; HILDYARD, N. (1984). The Social and environmental effects of large dams. San Francisco: Sierra Club Books.

GOTTSCHALK, L.C. (1964). Reservoir Sedimentation. In: Chow, Ven Te. Handbook of Applied Hydrology. New York, Mc Graw Hill, p. 17.1-17.33. 
GUERRA, A.J.T. (1994). Processos Erosivos nas Encostas. In: GUERRA, A.J.T. \& CUNHA, S.B. (orgs.). Geomorfologia: Uma Atualização de Bases e Conceitos. Ed. Afiliada. p. 149-209.

IGNIZIO, J.P. (1982). Linear Programming in Single \& Multiple-Objective Systems. Englewood Cliffs, NJ: Prentice-Hall.

INFANTI, J.N.; FORNASARI, F.N. (1998). Processos de dinâmica superficial. In: Geologia de Engenharia. São Paulo: ABGE, p. 131-152.

INTERNATIONAL COMMISSION ON LARGE DAMS - ICOLD. (1989). Sedimentation Control of Reservoirs. Guidelines, Paris, Bulletin 67.

LANE, E.W. (1955). The Importance of Fluvial Morphology in Hydraulic Engineering. American Society of Civil Engineering, Proceedings, 81, paper 745: p. 1-17.

LERNER, G.L.S. (2006). Estudo de impacto na geração hidroelétrica ao longo do rio São Francisco devido a transposição de suas águas utilizando modelo matemático de fluxos em rede AcquaNet. Dissertação (Mestre em Planejamento Energético). Universidade Federal do Rio de Janeiro. 108 p.

LINSLEY, R.K.; FRANZINI, J.B. (1972). Ingeniería de Los Recursos Hidráulicos. Compañía Editorial Continental, S.A., $4^{\text {th }}$. Edición, México.

MACHADO, W.C.; CAMARGO, P.O.; LUIZ, S.; SILVA, R.A.C.; ITAME, O.Y. (1999). Levantamento Batimétrico do Reservatório do Rio Santo Anastácio. In: XIX Congresso Brasileiro de Cartografia, Recife, CD ROM, v. 1.

MAHMOOD, K. (1987). Reservoir Sedimentation. Impact, extent and mitigation. World Bank Technical Paper, n. 71. Washington, DC. 118 p.

MAIA, A.G. (2006). As conseqüências do assoreamento na operação de reservatórios formados por barragens. Tese (Doutorado em Engenharia Civil). Escola de Engenharia de São Carlos, Universidade de São Paulo, São Carlos, 273 p. 
MAIA, A.G.; VILLELA, S.C. (2009). Análise do assoreamento do reservatório de Promissão através do modelo RESSASS. Ambiência (UNICENTRO), v. 5, p. 247-262.

MAIA, A.G.; VILLELA, S.C. (2006). A Interferência do Assoreamento na Operação de Reservatórios. In: IV Semana de Estudos de Engenharia Ambiental, Irati. Engenharia Ambiental: atualidades e tendências. Guarapuava : Unicentro, v. 1. p. 89-114.

MCCULly, P. (2001). Ríos silenciados. Ecología y política de las grandes represas. Argentina: Proteger Ediciones, 450 p.

MENDES, C.A.B.; CIRILO, J.A. (2001). Geprocessamento em Recursos Hídricos: Princípios, integração e aplicação. Porto Alegre: ABRH, Coleção Geoprocessamento, vol. 1.

MIRANDA, R.B.; ESTIGONI, M.V.; SCARPINELLA, G.A.; MAUAD, F.F. (2010). A Utilização de Levantamento Batimétrico para Atualização de Dados Operacionais de Reservatórios Modificados devido ao Assoreamento - Estudo de Caso: Reservatório de Três Irmãos/SP. In: IX Encontro Nacional de Engenharia de Sedimentos - Na busca por soluções para problemas de erosão e assoreamento, Brasília.

MORRIS, G.L; FAN, J. (1997). Reservoir sedimentation handbook. Mcgraw-HILL. New York. 365 p.

MULLER, A.C. (1995). Hidrelétricas, Meio Ambiente e Desenvolvimento. Makron Books. São Paulo. 412 p.

NAGLE, G.N.; FAHEY, T.J.; LASSOIE, P.J. (1999). Management of sedimentation in tropical watersheds. Environmental Management, Nova York, v. 23, nº 4, p. 441-452.

OPERADOR NACIONAL DO SISTEMA ELÉTRICO - ONS. (2010). Série de Vazões Naturais Médias Mensais. Disponível em: http://www.ons.org.br/operacao/vazoes_naturais.aspx>. Acesso em: 20 ago. 2010. 
OPERADOR NACIONAL DO SISTEMA ELÉTRICO - ONS. (2004). Evaporações Líquidas nas Usinas Hidrelétricas. $61 \mathrm{p}$.

PAIVA J.M.O. (1993). Sedimentação de reservatórios de barragens. Dissertação (Mestrado em Engenharia Hidráulica), Escola Politécnica, Universidade de São Paulo, São Paulo, 217 p.

PAIVA, E.M.C.D.; PAIVA, J.B.D.; REINERT, D.J. (1998). Estimativa do assoreamento do reservatório do DNOS, em Santa Maria, RS. In: XVII Congreso Nacional Del Água, II Simpósio de Recursos Hídricos Del Conosur, Santa Fé - Argentina.

PAIVA, E.M.C.D.; PAIVA, J.B.D.; MOREIRA, A.P.; MAFFINI, G.F.; MELLER, A.; DILL, P.R.J. (2001). Evolução de processo erosivo acelerado em trecho do arroio Vacacaí Mirim. Revista Brasileira de Recursos Hídricos, Porto Alegre, v.6 n.2 p.129-134.

POÇANO, W.L.; GIMENEZ, A.F; LEITE, A.A.G.; CARLSTRON FILHO, C.; PRADINI, L.F.; MELO, M.S. (1981). Metodologia para estudo de assoreamento de reservatório (III): roteiro para estudo de reservatórios no sul e sudeste brasileiro. In: CBGE, 3, Itapema (SC), Anais. São Paulo. ABGE. p. 331-353.

PONCE, R.J.C. (1986). Implantação de uma metodologia de cálculo de assoreamento de reservatórios com aplicação à bacia do Rio Sinu - Colômbia. Dissertação (Mestrado em Hidráulica e Saneamento). Escola de Engenharia de São Carlos. Universidade de São Paulo, São Carlos 172 p.

PORTO, R.L.; ROBERTO, A.N.; (2002). Manual do Usuário - AcquaNet. Escola Politécnica da Universidade de São Paulo, Laboratório de Sistemas de Suporte a Decisão. 22 p.

PORTO, R.L.L.; ROBERTO, A.N.; SCHARDONG, A.; MÉLlO JÚNIOR, A.V. (2003). Sistema de suporte a decisão para análise de sistemas de recursos hídricos. In: Silva, R.C.V. Métodos numéricos em recursos hídricos. Porto Alegre: ABRH, cap.2, p. 93-240. 
PORTO, R.L.; BOMBONATO NETO, C.; LISBOA NETO, H.; CASTRO, H.L.; SILVA, S.A. (1999). Sistema de suporte à decisões para a operação dos grandes sistemas produtores da SABESP. In: Simpósio de Hidrologia Urbana e Drenagem., Belo Horizonte, Água em quantidade e qualidade : o desafio do próximo milênio. Porto Alegre : ABRH, p. 323.

RAUDKIVI, A.J. (1993). Sedimentation: exclusion and removal of sediment from diverted water. Hydraulic Structures Design Manual, n. 6. Nova York: Livrenoir, 173 p.

ROBERTO, A.N. (2002). Modelos de rede de fluxo para alocação da água entre múltiplos usos em uma bacia hidrográfica. Dissertação (Mestrado em Engenharia Hidráulica e Sanitária). Escola Politécnica. Universidade de São Paulo. 105 p.

ROBERTO, A.N.; PORTO, R.L. (2001). O Sistema ModSimLS: um Modelo de Rede de Fluxo para Simulação de Bacias Hidrográficas. XIV Simpósio Brasileiro de Recursos Hídricos. V Simpósio de Hidráulica e Recursos Hídricos dos Países de Língua Oficial Portuguesa, Aracaju: ABRH, CD-ROM.

ROBERTO, A.N.; PORTO, R.L. (1999). Alocação da Água entre Múltiplos Usos em uma Bacia Hidrográfica. In: Simpósio Brasileiro de Recursos Hídricos, XIII Simpósio de Hidrologia Urbana e Drenagem. Belo Horizonte: ABRH.

ROCHA, J.S.M. (1997). Manual de Projetos Ambientais. Ministério do Meio Ambiente, dos Recursos Hídricos e da Amazônia Legal (MMA). Brasília, DF, 423 p.

SADOUN, B. (2000). Applied System Simulation: a review study. Information Science. Elsevier Science Inc. vol. 124. p. 173-192.

SALOMÃO, F.X.T. (1991). Erosão e a ocupação rural e urbana. In: Curso de Geologia Aplicada a Problemas Ambientais. AGAMA-DIGEM, v. 1.

SANTOS, I.; FILL, H.D.; SUGAI, M.R.V.B.; BUBA, H.; KISHI, R.T.; MARONE, E.; LAUTERT, L.F.C. (2001). Hidrometria Aplicada. LACTEC - Instituto de Tecnologia para o Desenvolvimento, Curitiba, v.1, 372 p. 
SCARPINELLA, G.D.; MAUAD, F.F. (2010). Uso do entorno de reservatórios e emprego de matas ciliares: uma revisão. In: XXIV Congresso Latino-americano de Hidráulica, Punta del Este, CD-ROM.

SHEN, H.W.; LAI, J.S. (1996). Sustain reservoir useful life by flushing sediment. International Journal of Sediment Research, Beijing, vol. 11, n.3, p. 11-17.

SOUZA, L.A.P. (2006). Revisão crítica da aplicabilidade dos métodos geofísicos na investigação de áreas submersas rasas. Tese (Doutorado em Ciências, Área de Oceanografia Química e Geológica). Instituto Oceanográfico, Universidade de São Paulo, São Paulo, $311 \mathrm{p}$.

SUGUIO, K.; BIGARELlA, J.J. (1979). Ambiente fluvial. Ambientes de sedimentação sua interpretação e importância. Universidade Federal do Paraná, Associação de Defesa e Educação Ambiental, Curitiba, p. 22-38.

SUN, Y.H.; YEH, W.W.G; HSU, N.S.; LOUIE, P.W.F. (1995). Generalized Network Algorithm for Water-Supply System Optimization. Journal of Water Resources Planning and Management, ASCE, v.121, n.5, p. 392-398.

UNIVERSIDADE ESTADUAL PAULISTA - UNESP. (2010). Canal de Pereira Barreto. Disponível em: $<$ http://www.dee.feis.unesp.br/museu/canal_pereira_barreto/canal_pereira_02.html/>. Acesso em: 30 set. 2010.

VALERA, N.E.; IZQUIERDO, G.C. (1984). Problemas y soluciones de sedimentación en la planta del bajo Anchicaya. In: Seminario Latinoamericano Sobre Presas y Embalses, 1., Bogotá.

VANONI, V.A. (1977). Sedimentation Engineering. American Society of Civil Engineers. New York. 
VILHENA, R.M.; ROIG, H.L.; MENESES, P.R. (2003). Determinação do Assoreamento de Reservatório Utilizando Técnicas de Geoprocessamento, o Caso do Reservatório de Funil - RJ. In: Anais XI SBSR, Belo Horizonte, p. 2649-2651.

VILLELA, S.M.; PONCE, R.J.C. (1986). Assoreamento de Reservatórios. Boletim de Hidráulica e Saneamento, v.1, n.8, 30 p.

YEH, W.W.G. (1985). Reservoir Management and Operations Models: A State-of-theArt Review, Water Resources Research, vol. 21, n 12, p. 1797-1818.

YOON, N. (1992). The state and the perspective of the direct sediment removal methods from reservoirs. International Journal of Sediment Research, Beijing, vol. 7, n. 2, p. 99-116.

WIKIMEDIA (2010). Ilustração de uma usina hidrelétrica. Disponível em: $<$ http://upload.wikimedia.org/wikipedia/commons/7/71/Hydroelectric_dam_portuguese.PNG >. Acesso em: 03 out. 2010.

WILKINSON, B.H. (2005). Human as geologic agents: A deep-time perspective. Geology, 33(3), p. 161-164.

WURBS, R. (1993). Reservoir-System Simulation and Optimization Models. Journal of Water Resources Planning and Management, ASCE, v.119, n.4, p. 455-472. 